
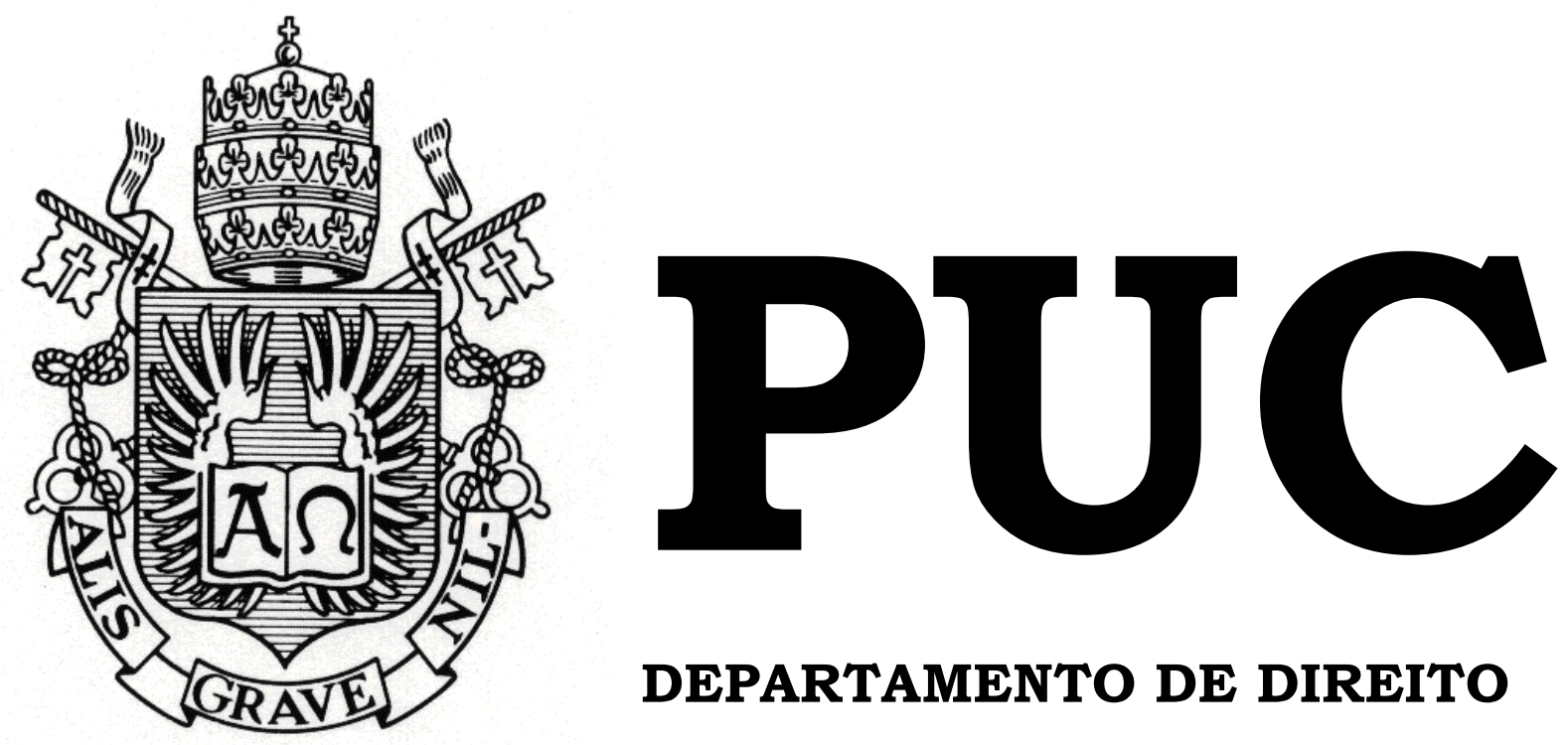

DEPARTAMENTO DE DIREITO

\title{
A RESPONSABILIDADE PENAL DOS PSICOPATAS
}

\author{
por \\ ALEXANDRA CARVALHO LOPES DE OLIVEIRA
}

ORIENTADOR: BRENO MELARAGNO COSTA

2012.2

PONTIFÍCIA UNIVERSIDADE CATÓLICA DO RIO DE JANEIRO

RUA MARQUÊS DE SÃO VICENTE, 225 - CEP 22453-900

RIO DE JANEIRO - BRASIL 


\section{A RESPONSABILIDADE PENAL DOS PSICOPATAS}

por

\section{ALEXANDRA CARVALHO LOPES DE OLIVEIRA}

Monografia apresentada ao Departamento de Direito da Pontificia Universidade Católica do Rio de Janeiro (PUC-Rio) para a obtenção do Título de Bacharel em Direito.

Orientador: Breno Melaragno Costa 
"Todos eles estão na mão de um poder que é mais forte do que a Morte. A esta, dizem, vence o amor; a Loucura, porém, nem ele."

Lima Barreto - Diário do hospício 


\section{AGRADECIMENTOS}

Agradeço, primeiramente, às minhas queridas avós pelo incentivo à leitura e aos estudos desde criança;

Ao meu amado pai, que sempre me acompanha em todas as etapas da minha vida;

Às minhas irmãs, pela união, amizade e amor que cultivamos, mesmo à distância;

Ao Edu, por ter compartilhado todas as alegrias e sucessos, pela paciência, amor, carinho e companheirismo. Que seja eterno!

Por fim, ao caríssimo mestre e orientador, Prof. Breno Melaragno, por toda dedicação e atenção, dignas de um grande amigo. 


\section{RESUMO}

O presente trabalho busca estudar a figura do psicopata na sociedade e a resposta dada pelo Direito Penal Brasileiro nos casos de crimes cometidos por estes indivíduos. Em primeiro lugar, a pesquisa tem foco principal na teoria do crime, para que se possam destrinchar todos os elementos pertencentes ao conceito analítico de crime, com especial atenção à culpabilidade e a imputabilidade. Posteriormente, no âmbito psiquiátrico e psicológico, os estudos serão relacionados à definição de psicopatia e suas principais características, determinando assim quem é o psicopata. Utilizando-se da Psicologia, dos exames da neurociência moderna e da Filosofia, entrar-se-á na questão dos julgamentos morais, tendo em vista haver discussão se os psicopatas são ou não capazes de realizar tais julgamentos antes de agir (análise de como os julgamentos morais influenciam em sua tomada de decisão). Por fim, o estudo irá abordar a psicopatia sob a ótica do Direito Penal, no que tange às leis (ou a falta delas) e à jurisprudência brasileira, indicando o tratamento dispensado pelo ordenamento jurídico nos casos de criminosos psicopatas.

Palavras-chave: psicopatas, psicopatia, direito penal, culpabilidade, imputabilidade. 


\section{SUMÁRIO}

INTRODUÇÃO ................................................................................................. 06

CAPÍTULO 1 - CULPABILIDADE ........................................................... 09

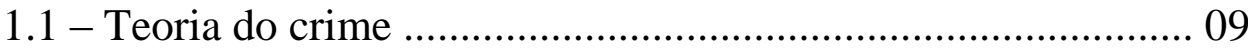

1.2 - Culpabilidade …………………………………................ 17

CAPÍTULO 2 - O CONCEITO DE PSICOPATIA ................................. 39

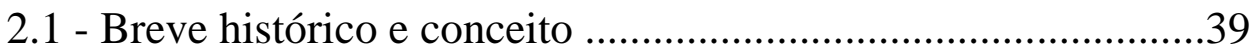

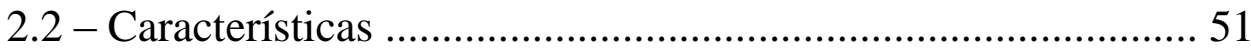

2.3 - Psicopatas e julgamentos morais ................................................ 60

CAPÍTULO 3 - A RESPONSABILIDADE PENAL DOS PSICOPATAS......................................................................................................... 68

CONCLUSÃO

REFERÊNCIAS BIBLIOGRÁFICAS.....................................................96 


\section{INTRODUÇÃO}

O estudo da mente criminosa sempre foi um importante tema discutido no Direito Penal. As mais diversas Escolas Penais trataram do assunto ao longo do tempo, tanto no âmbito da análise do criminoso em si, em suas compleições físicas - como Cesare Lombroso já afirmava na Escola Positiva - quanto em suas características psicológicas e das circunstâncias em que o fato típico foi cometido.

A Criminologia surgiu, então, como área de Ciência Penal que abarca um conjunto de conhecimentos acerca destes pontos principais (análise do delinquente, de sua conduta e das circunstâncias em que ocorreu o crime), fornecendo instrumentos necessários para o estudo criminológicosocial e oferecendo informações para a criação e aperfeiçoamento das leis penais. ${ }^{1}$

Entender as razões sociais e morais, além das motivações que levam a um indivíduo delinquir, analisando sua personalidade e também a perspectiva sócio-cultural em que está inserido, é de suma importância para a aplicação da lei penal ao caso concreto. Os juízes, por exemplo, necessitam de tal avaliação para que possam, conjuntamente com outros indícios e provas, absolver, fixar a pena adequada e proporcional ou então aplicar medida de segurança ao caso concreto.

Por estas razões, a Psicologia Forense, como ramo da Criminologia ${ }^{2}$, determinou conceitos e elencou elementos relevantes tanto para a área da Psicologia quanto do Direito, exatamente no intuito de fornecer o material importante para que se possa fazer uma análise acurada do delinquente.

\footnotetext{
${ }^{1}$ HASSEMER, Winfried; CONDE, Francisco M. Introduccion a la criminologia y al derecho penal. ed. Tirant Lo Blanch, Valencia: 1989, p. 17-18.

${ }^{2}$ Ibid. p. 16.
} 
Neste contexto, surge uma figura importante no cenário da Psicologia Forense: o psicopata. A Psicopatia é o tema central desta pesquisa, e será mais bem definida e explicada em capítulo específico. Saber como agem tais indivíduos e a resposta do Direito Penal diante dos crimes cometidos pelos mesmos é de extrema relevância, para que possamos aprimorar cada vez mais os tratamentos destes e criar novas políticas criminais que protejam a sociedade.

A pesquisa foi dividida em três momentos. Em uma primeira fase, a Teoria do Crime será destrinchada, com foco principal no elemento "culpabilidade". Analisar todos os elementos do conceito analítico de crime, com especial cuidado nas questões da imputabilidade, torna-se essencial para começar a se questionar se a psicopatia pode ensejar a imputabilidade plena, reduzida ou nula.

Posteriormente, em um segundo momento, será analisado o conceito de psicopata. Para tanto, serão analisados textos de Psicologia para que se possa definir o conceito de psicopata, além de mostrar como a neurociência, por meio de fMRI - Functional magnetic resonance imaging - e outras técnicas de imagem, tem definido a psicopatia. Após, será discutida a questão acerca de seus julgamentos morais. Muitos estudos foram realizados no intuito de saber se o indivíduo que é entendido como psicopata é capaz ou não de realizar julgamentos morais e de determinar (ou não) sua conduta de acordo com tais entendimentos. Tal explicação filosófica é elemento complementar a se pesquisar, eis que bom indicativo acerca de sua responsabilidade penal.

O resultado desta segunda fase tem influência direta sobre o terceiro momento da pesquisa. Trataremos da questão jurídica do psicopata: qual a resposta oferecida pelo Direito Penal para os crimes cometidos por estes sujeitos? Neste sentido, abordaremos a inimputabilidade, os meios de punição eficazes para prevenção e retribuição e como os tribunais 
brasileiros e estrangeiros têm decidido em tais situações. Para tanto, esta observação será feita através de pesquisa de jurisprudência nos sites do Supremo Tribunal Federal, do Superior Tribunal de Justiça e dos principais Tribunais de Justiça do país.

Além disso, serão analisados projetos de lei que possam vir a tratar de algum tema relacionado à psicopatia. Por fim, serão trazidos alguns julgados norte-americanos a fim de ilustrar a atuação dos tribunais estrangeiros quando deparados com este tema.

Desta forma, o objetivo principal do presente trabalho é colocar em debate a figura do psicopata no Judiciário Brasileiro. Primeiro porque este tema é pouco discutido no país, seja por psiquiatras seja por estudiosos do Direito. Além disso, diante da existência destes indivíduos na sociedade, e, pelo fato de alguns deles cometerem fatos criminosos, é importante haver um estudo interdisciplinar sobre tal realidade, a fim de coibir e prevenir a prática dos fatos delituosos. 


\section{CAPÍTULO 1 - CULPABILIDADE}

\section{1 - Teoria do crime}

O Direito Penal tem por finalidade precípua a proteção dos bens e valores mais importantes e necessários para que haja a possibilidade de sobrevivência em sociedade. ${ }^{3}$ É, por assim dizer, um dos "meios de controle social". ${ }^{4}$ Para tanto, elenca determinados bens que são considerados valiosos para a vida em comum e os protege com a chancela penal. Condutas que lesionam ou possam vir a ameaçar a integridade destes bens jurídicos tutelados serão consideradas criminosas, sujeitas às sanções previstas em lei.

Nos ensinamentos de Liszt, "Direito Penal é o conjunto de regras jurídicas estabelecidas pelo Estado, que associam o crime, como fato, à pena, como legítima consequência". 5 Em uma leitura moderna, deve-se, ainda, incluir as medidas de segurança como resposta estatal a um crime cometido pelos inimputáveis.

Verifica-se se determinada conduta pode ser considerada crime, primeiramente, observando se estão preenchidos todos os requisitos necessários que determinam ser a ação ou omissão em referência delituosa

\footnotetext{
${ }^{3}$ GRECO, Rogerio. Curso de Direito Penal - Parte Geral - $11^{\mathrm{a}}$ ed. Niterói: Ed. Ímpetus, 2009. p. 5. Jakobs, por sua vez, acredita que o Direito Penal não atende a essa finalidade de proteção de bens jurídicos, pois, "quando é aplicado, o bem jurídico que terá de ser por ele protegido já foi efetivamente violado." Para o autor, haveria apenas a garantia de vigência da norma, ou seja, "o agente que praticou uma infração penal deverá ser punido para que se afirme que a norma penal por ele infringida está em vigor."

${ }^{4}$ PUIG, Santiago Mir. Direito Penal - Fundamentos e Teoria do Direito. São Paulo: Editora Revista do Tribunal, 2007. p. 33.

O autor informa que é apenas um meio de controle social pois há outros, como a família, a escola, a profissão, os grupos sociais, etc, mas que estes possuem um caráter informal, enquanto o Direito Penal é formalizado.

${ }^{5}$ PUIG, Santiago apud Von Liszt - Op. cit., p. 35.
} 
ou não. Muitas vezes uma conduta pode, aparentemente, configurar algum fato típico, mas não ser punível. ${ }^{6}$

Cumpre, então, explicitar quais são os elementos que devem estar presentes no caso concreto para que se configure uma infração penal, função da chamada teoria do crime.

A teoria do crime, ou do delito ${ }^{7}$, nas palavras de Zaffaroni, é a "parte da ciência do direito penal que se ocupa de explicar o que é o delito em geral, isto é, quais são as suas características que devem ter qualquer delito. Esta explicação não é um mero discorrer sobre o delito com interesse de pura especulação, contrariamente atende ao cumprimento de um propósito essencialmente prático, consistente em tornar mais fácil a averiguação da presença, ou ausência, do delito em cada caso concreto" ${ }^{\prime 8}$ (grifos do autor).

Trata-se, então, de uma vertente da chamada Dogmática JurídicoPenal que estuda o crime como fato punível, do ponto de vista jurídico, para estabelecer suas características gerais. ${ }^{9}$

São diversas as maneiras de conceituar um crime. Pelo chamado conceito material, crime seria aquilo que simplesmente viola um bem penalmente protegido. ${ }^{10}$ Esta definição tem por preceito a visão ontológica do delito, os motivos que levaram o legislador a escolher certos valores e fundamentos e criminalizar determinadas condutas que violem estes bens. ${ }^{11}$

\footnotetext{
6 ZAFFARONI, Eugenio Raúl; PIERANGELI, José Henrique. Manual de Direito Penal Brasileiro: Parte Geral. 5a ed. São Paulo: Editora Revista dos Tribunais, 2004. p. 365. Zaffaroni traz o exemplo de um rapaz que supostamente teria furtado uma jóia em uma joalheria. Seria preciso averiguar se esta conduta realmente pode ser considerada um delito, já que, apesar de se amoldar ao art. 155 do CP, é preciso observar o caso concreto - talvez tenha se apoderado por engano, ou porque necessitava de dinheiro para a cirurgia de seu filho que corria perigo de vida, ou que a jóia fosse sua e acreditasse que pertencia ao joalheiro, etc.

${ }^{7} \mathrm{O}$ ordenamento jurídico brasileiro, ao contrário do sistema francês, não adota diferenciação entre "crime" e "delito", sendo usado nesse trabalho como sinônimos.

${ }^{8}$ ZAFFARONI, Eugenio. Op. cit., p. 365.

${ }^{9}$ FRAGOSO, Heleno Cláudio. Lições de Direito Penal: parte geral. 16 ${ }^{\mathrm{a}}$. ed. Rio de Janeiro: Editora Forense, 2004. p. 171.

${ }^{10}$ JESUS, Damásio de. Direito Penal: Parte Geral - $31^{\mathrm{a}}$ ed. São Paulo: Editora Saraiva, 2010. p. 193.

${ }^{11}$ BIERRENBACH, Sheila. Teoria do Crime. Rio de Janeiro: Editora Lumen Juris, 2009. p. 5.
} 
Afirma Manzini que delito é ação ou omissão, imputável a uma pessoa, lesiva ou perigosa a interesse penalmente protegido, constituída de determinados elementos e eventualmente integrada por certas condições ou acompanhadas de determinadas circunstâncias previstas em lei. ${ }^{12}$ Nesse caso, o delito não é apenas uma conduta que viola a lei, mas sim um fato socialmente nocivo e injusto, que viola o dever jurídico e ataca às condições fundamentais da vida em sociedade. ${ }^{13}$

Por sua vez, o conceito formal tem como ponto nodal a lei, a violação da norma penal. ${ }^{14}$. Nesse sentido, crime seria a infração de um preceito jurídico previsto em lei, que tem por consequência uma sanção. ${ }^{15}$

Existe ainda o chamado sistema formal-material, que conjuga os aspectos formais e materiais supramencionados. Assim, delito seria " $a$ infração da lei do Estado, promulgada para proteger a segurança dos cidadãos, resultante de um ato externo do homem, positivo ou negativo, moralmente imputável e politicamente danoso."16 A violação, então, desrespeita tanto à lei (formal) quanto o bem jurídico eleito pela sociedade a ser protegido (material).

Um quarto critério, denominando formal, material e sintomático, inclui nas definições formais e materiais a personalidade do agente. Nesse sentido, delito seria "fato humano tipicamente previsto por norma jurídica sancionada mediante pena em sentido estrito (pena criminal), lesivo ou perigoso para bens ou interesses considerados merecedores da mais enérgica tutela, constituindo expressão reprovável da personalidade do agente, tal como se revela no momento de sua realização." 17

\footnotetext{
${ }^{12}$ Ibid. p. 193.

${ }^{13}$ TUBENCHLAK, James. Teoria do Crime: O estudo do crime através de suas divisões. Rio de Janeiro: Editora Forense, 1978. p. 26.

${ }^{14}$ BIERRENBACH, Sheila. Op. cit.,. p. 5.

${ }^{15}$ Ibid. p. 25.

${ }^{16}$ JESUS, Damásio de. Op, cit.,. p. 192.

${ }^{17}$ Ibid. p. 192-193.
} 
Nenhum desses conceitos, entretanto, seria capaz de conceituar precisamente o que é um crime, já que não conseguem defini-lo especificamente. Isso porque, por exemplo, não consideram a possibilidade de exclusão de ilicitude ou dirimente de culpabilidade (conceito formal) ou ignoram o princípio da legalidade (conceito material), já que se pode atentar a bem jurídico importante, mas que não é penalmente tutelado. ${ }^{18}$

O chamado conceito analítico ${ }^{19}$ (também conhecido como dogmático) trouxe as maiores contribuições para determinar o que seria um delito. Adotando os estudos de Berner acerca de "ação", de Liszt e Beling sobre "ilicitude" e de Merkel e Binding e a "culpabilidade", ${ }^{20}$ determinouse que delito seria a ação ou omissão típica, antijurídica e culpável. ${ }^{21}$ Tal conceito explicitou os três elementos importantes e integrantes do delito, quais sejam, a tipicidade, a antijuridicidade e a culpabilidade. ${ }^{22}$

Sob a égide da estratificação do delito ${ }^{23}$, para que se possa determinar se determinada conduta, comissiva ou omissiva, pode ser considerada criminosa, é preciso responder, sucessivamente, a todas as etapas de configuração do fato. Isto é, primeiro precisamos observar se o requisito tipicidade foi preenchido. Caso a resposta seja positiva, existindo ação ou omissão que viola a norma prevista na lei, passamos a analisar a antijuridicidade da conduta. Ultrapassada tal fase, inexistente alguma causa de exclusão de ilicitude, buscamos averiguar a culpabilidade do agente. Estando presentes estes três momentos, pode-se afirmar que se está diante de um crime.

\footnotetext{
${ }^{18}$ GRECO, Rogerio. Op. Cit.,. p. 143.

${ }^{19}$ Ibid. p. 143. Recebe o nome de "analítico" pois analisa as características ou elementos que compõem a infração penal.

${ }^{20}$ Ibid. p. 143.

${ }^{21}$ FRAGOSO, Heleno Cláudio. Op. cit., p. 178.

Afirma Heleno Fragoso que o delito é um todo unitário, insuscetível de fragmentação em elementos. Seria mais adequado, então, falar em "características" ou "requisito" do que em elementos. Tal questão evidentemente é mais terminológica, não afetando qualquer essência do conceito analítico de crime.

${ }^{22}$ Ibid. p. 27.

${ }^{23}$ ZAFFARONI, Eugenio Raúl, Op. cit., p. 368
} 
Em breve síntese, tipicidade é "a subsunção (ou adequação) da conduta concreta praticada pelo agente à conduta abstrata descrita na figura penal incriminadora. Ambas as condutas devem ajustar-se, perfeitamente, sem que nada falte ou nada sobre". ${ }^{24}$

A antijuridicidade (ou ilicitude), por sua vez, é "a relação de contrariedade entre a conduta praticada pelo agente e o ordenamento jurídico-penal como um todo. Toda conduta típica será também antijurídica, a menos que o agente atue sob o manto de uma excludente de antijuridicidade. 25

Por fim, a culpabilidade - objeto principal de estudo do presente capítulo - é reprovabilidade. Constitui um "juízo de censura que recai sobre o autor da conduta típica e ilícita, que configura o injusto". ${ }^{26}$

O sistema tripartido de definição de crime é o posicionamento majoritário da doutrina e jurisprudência brasileira. Entretanto, há quem adicione a esta estrutura a punibilidade, sendo crime, então, a ação típica, ilícita, culpável e punível ${ }^{27}$. Uma crítica que se faz a tal pensamento é que, na verdade, a punibilidade não faz efetivamente parte do delito, sendo somente a sua consequência ${ }^{28}$.

Por outro lado, há quem exclua deste conceito dogmático a culpabilidade. Damásio de Jesus, René Ariel Dotti, Mirabete e Delmanto, além de outros doutrinadores, entendem que o conceito formal de crime,

\footnotetext{
${ }^{24}$ BIERRENBACH, Sheila. Op. cit,. p. 9.

${ }^{25}$ Ibid. p. 9.

${ }^{26}$ Ibid. p. 9.

${ }^{27}$ PRADO, Luiz Régis. Curso de Direito Penal Brasileiro. $9^{\mathrm{a}}$ ed. São Paulo: Editoria Revista dos Tribunais, 2010. p. 246 - 247. Luiz Regis Prado argumenta que a punibilidade é examinada na teoria do delito, mas se compõe de dados de natureza diversa, objetivos ou subjetivos, concomitantes ou posteriores ao delito. Medeia entre o tipo do injusto culpável e a sua consequência jurídica, com outros caracteres e fundamentos. Tem, portanto, um conteúdo próprio e residual expresso em determinada condicionante à imposição da pena.

${ }^{28}$ GRECO, Rogerio. Op. cit., p. 147.
} 
sob o ponto de vista da lei, é apenas a ação típica e antijurídica, tendo a culpabilidade natureza de pressuposto da aplicação da pena. ${ }^{29}$

Independente da posição adotada, importante conceituar, ainda que brevemente, os elementos constantes da tipicidade e da antijuridicidade, para que se possa adentrar no campo da culpabilidade com maior profundidade.

Crime, então, é conduta típica, antijurídica e culpável. ${ }^{30}$ Não há definição no Código Penal Brasileiro de o que seria conduta ${ }^{31}$, se é ação ou omissão. $\mathrm{O}$ art. $1^{\mathrm{o}}$ da Lei de Introdução ao Código Penal dispôs apenas que “considera-se crime a infração penal que a lei comina pena de reclusão ou de detenção, quer isoladamente, quer alternativa ou cumulativamente com a pena de multa; contravenção, a infração penal a que a lei comina, isoladamente, pena de prisão simples ou de multa, ou ambas, alternativa ou cumulativamente."

Torna-se necessário, então, se socorrer ao histórico das teorias de conduta capazes de demonstrar quando o agir ou se omitir torna-se criminoso.

Não há crime sem conduta humana, seja ela comissiva ou omissiva. ${ }^{32}$ Em um conceito conhecido como "pré-clássico", Hegel apontava conduta como a exteriorização da vontade subjetiva ou moral. Só se reconheceria como ação aquilo que estava nos propósitos do agente ${ }^{33}$.

\footnotetext{
${ }^{29}$ Ibid. p. 147. Rogério Greco rebate este posicionamento afirmando que o raciocínio destes doutrinadores se deve ao fato de que o Código Penal, quando se refere à culpabilidade, utiliza geralmente expressões ligadas à aplicação da pena (ex. art. 26). Embora o diploma legal utilize tais expressões quando quer se referir à causas dirimentes de culpabilidade, tal opção legislativa não permite concluir que o crime seria, então, somente fato típico e antijurídico.

${ }^{30} \mathrm{O}$ presente trabalho adota o conceito analítico tripartido.

${ }^{31} \mathrm{O}$ tema "conduta" tem certa relevância no presente pois, em certo momento, se questionará se a conduta dos psicopatas, entendida como vontade, poderá ou não ser culpável.

32 BIERRENBACH, Sheila. Op. cit., p. 11. Manzini acreditava na existência de delito sem conduta, numa situação individual que, em si mesma, não constitui infração de nenhum mandamento ou proibição penal, senão que incriminada somente pela suspeita que desperta.

${ }^{33}$ Ibid. p. 12 - 13.
} 
Posteriormente, pela chamada teoria causalista de Liszt, Beling e Radbruch, a ação se definiria como comportamento humano voluntário, que produz modificação no mundo exterior, compreendendo um processo interno de vontade, a atuação dessa vontade - por meio de um fazer ou não fazer - e o resultado desta atuação. ${ }^{34}$ Sem o ato de vontade não haveria ação, inexistindo o agir não haveria mudança no mundo exterior (entendido por resultado) e, desta forma, não estaríamos diante de um crime.

Ainda nos moldes da teoria causalista, a teoria neoclássica afirma que a ação se define como comportamento humano voluntário manifestado no mundo exterior. ${ }^{35} \mathrm{~A}$ ação, segundo este pensamento, abarcava a ação strito sensu e a omissão. ${ }^{36}$

A teoria finalista da conduta de Welzel é a teoria mais famosa sobre conduta. Sob a ótica deste autor, a ação seria exercício de atividade final. A atividade final seria um agir conscientemente por um fim, enquanto o chamado "acontecer casual" não está dirigido ao fim. ${ }^{37} \mathrm{~A}$ ação seria, portanto, um comportamento humano voluntário dirigido a uma finalidade qualquer. $^{38}$

Por fim, a denominada "teoria social" da conduta prevê a ação como o comportamento voluntário relacionado ao mundo exterior. ${ }^{39}$ Em outras palavras, é o comportamento humano socialmente relevante.

Obviamente, ausente a conduta (por exemplo, nos casos de coação física irresistível, estados de inconsciência, atos reflexos, etc), não haverá como se falar em delito.

\footnotetext{
${ }^{34}$ FRAGOSO, Heleno Cláudio. Op. cit.,. p. 184.

${ }^{35}$ GRECO, Rogerio. Op. cit.,. p. 150.

${ }^{36}$ BIERRENBACH, Sheila. Op. cit., p. 17.

${ }^{37}$ Ibid. p. 18.

${ }^{38}$ GRECO, Rogerio. Op. cit., p. 151.

${ }^{39}$ BIERRENBACH, Sheila. Op. cit., p. 22.
} 
Ultrapassada as questões principais que envolvem a conduta, passase a analisar brevemente ${ }^{40}$ o elemento tipicidade, primeiro passo para verificar um delito. Denomina-se tipo penal ou figura típica a descrição da conduta criminosa apenada pela lei. ${ }^{41}$ Tem como principal função a individualização de condutas humanas penalmente relevantes. ${ }^{42}$

Um fato é típico quando composto pela conduta do agente, dolosa ou culposa, comissiva ou omissiva; pelo resultado e pelo nexo de causalidade entre aquela e este. ${ }^{43}$ Tipicidade, como já afirmamos anteriormente, quer dizer a perfeita subsunção entre a conduta do agente ao modelo abstrato previsto na lei penal.

Há três funções do tipo consideradas importantes. A primeira seria a função garantidora, uma vez que o agente somente poderá ser penalmente responsabilizado se cometer uma das condutas proibidas ou deixar de praticar aquelas imposta pela lei penal; a função fundamentadora, já que o Estado, por intermédio do tipo penal, fundamenta suas decisões e imposições; e a função selecionadora de condutas, já que o tipo tem a função de selecionar as condutas que deverão ser proibidas ou impostas pela lei penal, sob ameaça de sanção. ${ }^{44}$

Afastada qualquer hipótese que exclua a tipicidade da conduta (por exemplo, erro de tipo previsto no art. 20 do $\mathrm{CP}$ ), devemos analisar a antijuridicidade da conduta.

\footnotetext{
${ }^{40}$ Cumpre destacar que a pesquisa se focou no elemento culpabilidade, mas torna-se impossível falar deste terceiro requisito sem mencionar, ainda que brevemente, as principais características de tipicidade e antijuridicidade.

${ }^{41}$ BIERRENBACH, Sheila. Op. cit., p. 37.

${ }^{42}$ GRECO, Rogerio. Op. cit., p. 157.

${ }^{43}$ Ibid. p. 158.

${ }^{44}$ Ibid. p. 183.
} 
A tipicidade já é um grande indício de que aquele ato também é antijurídico. ${ }^{45}$ Pela chamada ratio cognoscendi, exerce essa função indiciária de ilicitude (somente não se confirmará se o agente atuar sob o manto de alguma justificação). ${ }^{46}$

A ilicitude é a contrariedade, oposição ao Direito, podendo se dividir em formal e material. Uma conduta seria formalmente antijurídica enquanto contrário a uma proibição legal, e materialmente antijurídica por implicar na lesão ou perigo de lesão a um bem jurídico, atacando interesses vitais particulares e coletivos protegidos pela lei penal. ${ }^{47}$

Inexistindo qualquer causa de exclusão de ilicitude (como as previstas no art. 23 do CP, por exemplo, a legítima defesa), verificamos que a conduta, até o presente momento, é típica e antijurídica, compondo o chamado "injusto penal". Porém ainda não estamos diante de um crime, adotando o conceito tripartido. Falta o elemento culpabilidade.

\section{2 - Culpabilidade}

A culpabilidade é, em conceito amplo e geral, compreendida como o juízo de reprovação pessoal que é realizado sobre a conduta típica e ilícita praticada pelo agente. ${ }^{48}$ Porém, antes de termos esta classificação, é necessário expor a evolução histórica do conceito de culpabilidade, para aprofundarmos o estudo nesse terceiro elemento.

A evolução do conceito de culpabilidade é a história das transformações do principal elemento que esta possui, qual seja, a consciência e vontade do fato. Posteriormente, este elemento é ampliado para consciência e vontade do fato e do valor do fato e, após, se reduz para consciência e vontade apenas do valor do fato, também chamada de consciência da antijuridicidade. Essas fases de consciência correspondem às

\footnotetext{
${ }^{45}$ BIERRENBACH, Sheila. Op. cit., p. 161.

${ }^{46}$ GRECO, Rogerio. Op. cit.,. p. 315.

${ }^{47}$ Ibid. p. 314.
} 
teorias psicológica, psicológica-normativa e normativa pura da culpabilidade. $^{49}$

Iniciando o estudo pela chamada "teoria psicológica da culpabilidade", também conhecida como clássica, observamos como principais expoentes Liszt e Beling, sendo aperfeiçoada posteriormente por Radbruch. ${ }^{50}$ Esta teoria seria produto do positivismo científico imperante no final do século XIX, momento em que se passou a ter como paradigma de ciência o estudo causal-explicativo, com base nas ciências naturais e sociais, impulsionadas pelas teorias de Darwin, Comte e Spencer. ${ }^{51}$

Para Liszt e outros doutrinadores, o delito poderia ser dividido em duas faces - a face objetiva, que era constituída pelo processo causal externo (conduta, resultado e nexo causal entre ambos) e a face subjetiva, que correspondia ao conteúdo da vontade. ${ }^{52}$

Nesse sentido, a culpabilidade seria a denominada parte subjetiva do delito, de conteúdo puramente psicológico, sendo determinada como o liame subjetivo entre o agente e sua conduta. ${ }^{53}$ A culpabilidade reside, então, na relação psíquica do autor com seu fato. ${ }^{54}$

Importante destacar que, antes desse posicionamento, a responsabilidade penal era objetiva, sendo o agente responsabilizado ainda que não tivesse agido com dolo ou culpa, bastando apenas que sua conduta causasse fisicamente o resultado. ${ }^{55}$ A simples causação física já ensejava a punição penal.

\footnotetext{
${ }^{48}$ Ibid. p. 281.

${ }^{49}$ SANTOS, Juarez Cirino. Teoria do crime. São Paulo: Editora Acadêmica, 1993. p. 59.

${ }^{50}$ BIERRENBACH, Sheila Op. cit.,. p. 193.

${ }^{51}$ PRADO, Luiz Régis. Op. cit.,. p. 381.

${ }^{52}$ BIERRENBACH, Sheila. Op. cit. p. 193-194.

${ }^{53}$ Ibid. p. 193-194.

${ }^{54}$ JESUS, Damásio de. Op. cit.,. p. 504.

${ }^{55}$ BIERRENBACH, Sheila. Op. cit., p. 194.
} 
Liszt afirmou, então, que a culpabilidade, como característica do delito, correspondia "à relação subjetiva entre o ato e o autor. Esta relação deve tomar como ponto de partida o fato concreto, mas ao mesmo tempo se aparta do mesmo, conferindo então ao ato o caráter de expressão de natureza própria do autor e deixando claro o valor metajurídico da culpabilidade., ${ }^{56}$

Por este entendimento, a culpabilidade seria o nexo psíquico que intermediaria o mundo sensível do autor e o resultado típico, tanto nos crimes dolosos quanto culposos. O dolo seria caracterizado pela intenção (ou assunção de risco) de o agente produzir o resultado, enquanto a culpa seria a inexistência dessa intenção ou assunção de risco de produzi-lo. ${ }^{57}$

Para os adeptos desta teoria, a culpabilidade era o lugar adequado dos estudos dos elementos subjetivos do tipo, o dolo e a culpa ${ }^{58}$ Antes, porém, de aferir no caso concreto se há a presença do dolo e da culpa, é preciso verificar se o agente era imputável, capaz de responder pelo injusto penal que cometeu. A imputabilidade era, então, tida como pressuposto da culpabilidade. ${ }^{59}$

Nas palavras de Ronaldo Tanus Madeira, a imputabilidade, nesta teoria, passa a exercer papel fundamental, já que

um doente mental jamais poderá agir com dolo ou culpa, porque, sem a capacidade psíquica para a compreensão do ilícito, não há nenhuma relação psíquica relevante para o Direito Penal, entre o agente e o fato. Sem a imputabilidade, não se perfaz a relação subjetiva entre a conduta e o resultado. Não se pode falar em dolo ou culpa de um doente mental. O dolo e a culpa, como formas de exteriorização da culpabilidade em direção à causação do resultado, pressupõem a imputabilidade do agente. ${ }^{60}$

\footnotetext{
${ }^{56}$ BIERRENBACH apud LIZST, op. Cit., pag. 194.

${ }^{57}$ JESUS, Damásio de. Op. cit.,. p. 504.

${ }^{58}$ GRECO, Rogerio. Op. cit.,. p. 385.

${ }^{59}$ Ibid. p. 385.

${ }^{60}$ Ibid. p. 385 .
} 
A imputabilidade, então, para Liszt, se dá com "aquele estado psíquico do autor que the garanta a possibilidade de conduzir-se socialmente, isto é, com a faculdade de determinar-se de um modo geral, pelas normas da conduta social, sejam pertencentes ao domínio da religião, da moral, da inteligência, etc., ou aos domínios do direito". ${ }^{61}$

Seria, neste sentido, dividida em quatro aspectos. O primeiro seria a capacidade de engendrar, com riqueza, representações para a completa valoração social. O segundo, a capacidade de associá-las de maneira normal e com velocidade normal. O terceiro seria a existência de uma base efetiva de tais representações, de tal maneira que a força motivadora das normas gerais corresponda à média do homem comum. Por fim, a normalidade tanto da direção, como do vigor dos impulsos da vontade. ${ }^{62}$

Podemos observar, então, que a concepção psicológica da culpabilidade exige dois elementos: a imputabilidade, como capacidade abstrata de compreender e querer (ou seja, representar corretamente o valor do fato e decidir de acordo com esta representação) e a relação psicológica entre o agente e o fato, sob as formas de dolo e de culpa (o primeiro como consciência e vontade do fato, enquanto o segundo como causação de resultado lesivo por imprudência, negligência ou imperícia). ${ }^{63}$

A culpabilidade somente poderia ser afastada se estivessem presentes causas que eliminassem esse vínculo psicológico entre o autor e o fato. As causas possíveis seriam o erro (que eliminaria o elemento intelectual) e a coação (eliminando o elemento volitivo do dolo). ${ }^{64}$

Note-se que, para esta teoria, a culpabilidade se confundia com dolo e culpa (sendo estes espécies da primeira), enquanto a imputabilidade seria

\footnotetext{
${ }^{61}$ TANGERINO, Davi apud LIZST. Culpabilidade. Rio de Janeiro: Elsevier. 2011, p. 59.

${ }^{62}$ Ibid. p. 59.

${ }^{63}$ SANTOS, Juares Cirino. Op cit., p. 59.

${ }^{64}$ BITENCOURT, Cezar Roberto. Op. cit., p. 418.
} 
o pressuposto da culpabilidade ${ }^{65}$ conforme explicitamos. Zaffaroni afirma que esta teoria denomina à culpabilidade aquilo que se considera, na verdade, o aspecto subjetivo do tipo. ${ }^{66}$

Em breve síntese, podemos afirmar que esta teoria determina que a culpabilidade seria a relação subjetiva ou psíquica entre o autor e o fato. Trata-se, então, de uma relação psicológica que tem como ponto inicial o fato concreto. ${ }^{67}$ Em suma, o "ato culpável é a ação dolosa ou culposa do indivíduo imputável"68 Assim, a teoria psicológica reunia os elementos subjetivos do delito na culpabilidade, considerando a imputabilidade como seu pressuposto. ${ }^{69}$

Entretanto, muitas críticas podem ser feitas em relação à teoria psicológica da culpabilidade. As discussões maiores giram em torno da culpa inconsciente e das condutas praticadas pelos doentes mentais. ${ }^{70}$

A primeira questão que se indaga é sobre a culpa. Não haveria ponto de identidade entre o dolo (caracterizado pelo "querer") e a culpa (caracterizada pelo "não querer”). Isto porque, para o dolo, realmente há a relação psicológica entre o agente e o fato, assim como nos casos de culpa consciente.

Porém, a "culpa", principalmente a inconsciente, é exclusivamente normativa, baseada no juízo que o magistrado faz a respeito da possibilidade de antevisão do resultado. ${ }^{71}$ Assim, seria impossível conjugar em um mesmo denominador comum (culpabilidade) um elemento normativo (culpa) e um elemento psíquico (dolo).

\footnotetext{
${ }^{65}$ BIERRENBACH, Sheila. Op. cit.. p. 195.

${ }^{66}$ ZAFFARONI, op. Cit pag 573

${ }^{67}$ PRADO, Luiz Régis. Op. cit., p. 381.

${ }^{68}$ PRADO, Luiz Régis Apud LIZST. Op. cit., p. 381.

${ }^{69}$ Ibid. p. 382.

${ }^{70}$ BIERRENBACH, Sheila. Op. cit.,. p. 195.

${ }^{71}$ JESUS, Damásio de Op. cit., p. 504.
} 
Um segundo ponto controverso é quanto à culpabilidade do doente mental. Isso porque, na conduta do doente mental existe o vínculo psicológico entre o agente e o fato, há essa relação nítida. Assim, sua conduta, por esta teoria, deveria ser considerada como culpável, e, portanto, como delituosa, quando, na verdade, não o é. ${ }^{72}$

Outras questões podem ser ainda levantadas: esta teoria não ordenava sistematicamente a imputabilidade, que ora era pressuposto do dolo e da culpa, ora pressuposto da pena; não explicava o estado de necessidade exculpante, visto que, mesmo presente o dolo, inexiste culpabilidade $;^{73}$ não compreendia a culpabilidade como um conceito graduável, afastando outros aspectos como as emoções, embriaguez e outras causas de exculpação, etc. ${ }^{74}$

Por estas razões, conclui-se que a teoria psicológica da culpabilidade foi, a seu tempo, uma grande revolução no pensamento do Direito Penal, afastando a possibilidade de responsabilização objetiva, como era anteriormente. Entretanto, críticas severas demonstraram o quão frágil era esta teoria, não abarcando diversas hipóteses penais importantes.

Diante deste quadro de insuficiência da culpabilidade, eis que surge a chamada "teoria psicológico-normativa", ou "normativa-complexa". O fundador desta teoria foi Reinhard Frank, que a concebeu visando a reprovabilidade sem afastar o dolo e a culpa. Este autor foi o primeiro a verificar que o momento psicológico que se exprime no dolo e na culpa não esgota todo o conteúdo da culpabilidade, vez que essa precisa também ser reprovável. ${ }^{75}$

\footnotetext{
${ }^{72}$ BIERRENBACH, Sheila. Op. cit., p. 195.

${ }^{73}$ PRADO, Luiz Régis. Op. cit., p. 382.

${ }^{74}$ BITENCOURT, Cezar Roberto. Op. cit., p. 419-420.

${ }^{75}$ Ibid. p. 420.
} 
A culpabilidade, para este pensamento, deixa de ser apenas um liame subjetivo entre o agente e o resultado, passando a ser um juízo de valor a respeito de um fato doloso (psicológico) ou culposo (normativo). Dolo e culpa tornam-se elementos da culpabilidade, e não espécies da mesma. ${ }^{76}$ Em outros termos, poderá existir o dolo sem que haja a culpabilidade, a exemplo das causas de exculpação, momentos em que há conduta dolosa, mas não há reprovabilidade. ${ }^{77}$

Cunhou-se o nome "psicológico-normativa", pois contém o dolo como elemento psicológico e a exigibilidade como fato normativo. Por exemplo, um sujeito que mata em estado de necessidade age dolosamente, mas sua conduta não é culpável, já que, diante da inexigibilidade de outro comportamento, não se torna reprovável. ${ }^{78}$

Logo, para que o agente pudesse ser punido pelo fato ilícito que cometeu, não bastaria apenas a presença do dolo e da culpa, mas sim que, nas condições em que se encontrava, podia-lhe exigir uma conduta conforme o direito. O conceito de exigibilidade da conduta passou a refletir-se sobre toda a culpabilidade. ${ }^{79}$

A estrutura da culpabilidade para esta teoria, então, seria a imputabilidade, o dolo e a culpa e a exigibilidade de conduta diversa. ${ }^{80} \mathrm{O}$ dolo conteria a consciência da ilicitude (também chamado de dolus malus), a imputabilidade deixa de ser pressuposto para se tornar elemento da culpabilidade e a inexigibilidade de outra conduta torna-se uma causa de exclusão de culpabilidade. ${ }^{81}$

\footnotetext{
${ }^{76}$ JESUS, Damásio de. Op. cit., p. 505.

${ }^{77}$ BITTENCOURT, op. Cit pag. 422-423

${ }^{78}$ JESUS, Damásio de. Op. cit., p. 504-505.

${ }^{79}$ GRECO, Rogerio. Op. cit., p. 387.

${ }^{80}$ Ibid. p. 388.

${ }^{81}$ PRADO, Luiz Régis. Op. cit., p. 383.
} 
A imputabilidade seria a possibilidade de se responsabilizar alguém pela prática de certo fato previsto na lei penal. Para tanto, seria necessário que o agente possuísse condições para entender o caráter ilícito do fato e de determinar-se de acordo com este entendimento. Deveria estar no pleno gozo de suas faculdades mentais para que pudesse atuar conforme o direito. $^{82}$

O dolo seria a vontade e a consciência de realizar o fato proibido pela lei, enquanto a culpa seria uma vontade defeituosa. Por ser entendido como dolus malus, além da vontade de realizar o fato seria necessário também o conhecimento sobre a ilicitude do fato. ${ }^{83}$ Era constituído, então, de vontade, previsão e consciência da antijuridicidade da ação. ${ }^{84}$

Por fim, o conceito de inexigibilidade de conduta diversa passou a ser entendida como exclusão de culpabilidade. Não poderia, então, atuar culpavelmente, aquele a quem não pode ser exigida uma conduta distinta da realizada. $^{85}$

Apesar de ser considerada um avanço no que tange à culpabilidade, não faltaram críticas à teoria psicológico-normativa da culpabilidade. Dentre as diversas discussões, três se destacam acerca deste pensamento.

Um primeiro ponto seria acerca da separação do dolo dos demais elementos subjetivos do tipo. Isso porque se consideraria assistemática essa separação, uma vez que os elementos subjetivos integrariam o tipo penal que os descrevesse, enquanto o dolo integraria a culpabilidade. ${ }^{86}$

Ademais, ainda quanto ao dolo, era possível verificar que este deixava de ser puramente psicológico, passando a ser um dolo "híbrido", sendo psicológico no que tange à vontade e à consciência e normativo

\footnotetext{
${ }^{82}$ Ibid. p. 388.

${ }^{83}$ Ibid. p. 388.

${ }^{84}$ BITENCOURT, Cezar Roberto. Op. cit.,. p. 423.

${ }^{85}$ GRECO, Rogerio. Op. cit., p. 388.

${ }^{86}$ BIERRENBACH, Sheila. Op. cit., p. 197.
} 
quanto à consciência da ilicitude. Com a adoção deste dolo híbrido, uma situação paradoxal surgia, quanto aos chamados "criminosos habituais", detectado por Mezger. ${ }^{87}$

O problema trazido por este autor se encontraria no fato que haveria sujeitos que, em virtude de seu meio social, não tinham a consciência da ilicitude necessária para configurar o dolo, pois, de regra, se criavam e se desenvolviam em meio a determinadas condutas ilícitas que eram consideradas "normais". De acordo com esta teoria, estes indivíduos agiam sem dolo, uma vez que lhes faltava a consciência da ilicitude. Logo, excluía-se a culpabilidade de agentes que tinham as ações mais censuráveis, configurando o tal paradoxo evidente. ${ }^{88}$

Uma segunda questão seria quanto à possibilidade ou não de tentativa. A teoria não explica a tentativa, uma vez que, para que esta se configure, é imprescindível a análise do dolo com que o agente praticou a conduta. Por fim, uma terceira crítica seria acerca da necessidade de se aguardar a análise da culpabilidade (depois de observada a tipicidade e a antijuridicidade) para distinguir o dolo e a culpa. ${ }^{89}$

Logo, apesar de a teoria psicológico-normativa também ser considerada uma evolução teórica no sistema causal, ${ }^{90}$ deixou muitas questões em aberto. Assim como a teoria psicológica, o fato de se embasar no sistema causal não abrangia todas as possibilidades existentes no direito. $^{91}$

Diante destas lacunas, surge a chamada "teoria normativa pura" ou "finalista", com seu maior expoente Hans Welzel e diversas mudanças importantes, principalmente quanto ao dolo e a culpa.

\footnotetext{
${ }^{87}$ BITENCOURT, Cezar Roberto. Op. cit., p. 424.

${ }^{88}$ Ibid. p. 424.

${ }^{89}$ BIERRENBACH, Sheila. Op. cit., p. 197.

${ }^{90}$ GRECO, Rogerio. Op. cit.,. p. 388.

${ }^{91}$ Ibid. p. 389.
} 
Em primeiro lugar, importante destacar que a teoria finalista de Welzel redefiniu muitos conceitos de direito. Conforme já expusemos anteriormente, a ação passou a ser indissociável de finalidade. É através da ação que percebemos a finalidade do agente. Toda conduta humana é impregnada de finalidade. ${ }^{92}$ Partindo dessa mudança, Welzel verificou que o dolo não poderia configurar mais como elemento de culpabilidade.

O dolo, na concepção causalista era considerado normativo, baseado no conhecimento da ilicitude, constituído como elemento da culpabilidade. ${ }^{93}$ Já o dolo finalista é o chamado "dolo natural", livre da necessidade de se aferir a consciência sobre a ilicitude do fato para sua configuração. $^{94}$

Assim, o dolo natural é constituído da consciência (ou conhecimento) e da vontade de praticar a conduta descrita na figura típica, destituído de qualquer consciência da antijuridicidade. Esta última permanece integrando a culpabilidade, como seu elemento. ${ }^{95}$

Culpabilidade, segundo Welzel, é a "reprovabilidade de decisão da vontade". ${ }^{96}$ Exclui-se, deste conceito, a maioria dos elementos subjetivos, anímicos ou psicológicos - integrantes do tipo do injusto - conservando-se, fundamentalmente, o critério valorativo da censurabilidade. ${ }^{97}$ Tem como base principal a capacidade da livre autodeterminação de acordo com o sentido do autor, isto é, poder ou a faculdade de atuar de modo distinto de como atuou. ${ }^{98}$

\footnotetext{
${ }^{92}$ Ibid. p. 390.

${ }^{93}$ BIERRENBACH, Sheila. Op. cit., p. 197.

${ }^{94}$ GRECO, Rogerio. Op. cit., p. 390.

${ }^{95}$ BIERRENBACH, Sheila. Op. cit., p. 198.

${ }^{96}$ PRADO, Luiz Régis apud WELZEL. Op. cit.,. p. 384.

${ }^{97}$ Ibid. p. 384.

${ }^{98}$ BITENCOURT, Cezar Roberto. Op. cit.,. p. 433.
} 
O conteúdo da culpabilidade sob a ótica finalista passa a ser, então, a imputabilidade, a possibilidade de conhecimento do injusto (potencial consciência da ilicitude) e exigibilidade de conduta diversa. ${ }^{99}$

A imputabilidade torna-se condição central de reprovabilidade, deixando de ser pressuposto da culpabilidade, posto que o núcleo da culpabilidade passa a ser as condições de atribuibilidade do injusto, baseado na ideia do "poder atuar de outro modo". 100

Quanto à possibilidade de conhecimento da antijuridicidade do fato, deve-se examinar se o agente poderia conhecer a proibição do fato, como condição para poder adequar sua conduta à norma. A falta dessa possibilidade não exclui o dolo, podendo apenas afastar a culpabilidade. ${ }^{101}$

Por fim, há ainda a possibilidade de eximir o agente da censura da culpabilidade quando presente alguma causa de exculpação, impedindo que o mesmo pudesse atuar de outro modo naquela situação. ${ }^{102}$

Portanto, não há como negar que a teoria finalista de Welzel e a teoria normativa pura foram marcos na evolução da culpabilidade. Ainda assim, foi alvo de críticas, principalmente quanto à separação entre culpabilidade e ilicitude, dolo eventual e culpa em sentido estrito. ${ }^{103}$

Por exemplo, no que tange à culpa, Welzel afirmava que o resultado nos delitos culposos derivava da inobservância do mínimo de direção finalista capaz de impedir a sua produção. Assim, o fato imprudente seria "evitável finalmente", o que introduzia no conceito um momento valorativo, próprio da culpabilidade e não do tipo. ${ }^{104}$

\footnotetext{
${ }^{99}$ JESUS, Damásio de. Op. cit.,. p. 506.

${ }^{100}$ PUIG, Santiago Mir. Op. cit.,. p. 415.

101 Ibid. p. 415.

102 Ibid. p. 415.

103 JESUS, Damásio de. Op. cit., p. 507.

104 Ibid. p. 507.
} 
Outras teorias acerca da culpabilidade surgiram ao longo do tempo. A teoria social da ação, por exemplo, define a ação como fenômeno social, tentando englobar aspectos do causalismo e do finalismo. ${ }^{105}$ Diziam que a ação era entendida como socialmente relevante, dominada (ou dominável) pela vontade humana. A relevância social da conduta somente é verificada se produzir efeitos danosos na relação do indivíduo com seu ambiente social. ${ }^{106}$

Outra teoria é a chamada teoria complexa da culpabilidade. Para os adeptos dessa teoria, o dolo passa a ter dupla função na estrutura do delito. No tipo penal, ele funcionaria como elemento subjetivo, a relação psicológica entre o autor e o fato. Na culpabilidade, o dolo representaria uma atitude interna juridicamente censurável, um ânimo adverso ou indiferente ao Direito, demonstrando a oposição do agente ao ordenamento jurídico-penal. ${ }^{107}$

Nesse sentido, a tipicidade passa não somente a ser indício da antijuridicidade, como também da culpabilidade. Surgiria, assim, uma "culpabilidade dolosa", referente a uma atitude de menosprezo ou indiferença ao direito, e uma "culpabilidade culposa" representando um retrocesso ao finalismo. ${ }^{108}$.

Por fim, existe ainda a chamada teoria limitada da culpabilidade, que seria uma das modalidades da teoria normativo pura. Para o professor Damásio de Jesus, é a teoria adotada pela reforma penal de 1984 . O principal ponto desta teoria é a distinção entre a ignorância da ilicitude por erro que recai sobre a regra de proibição e a ignorância de ilicitude por erro incidente sobre a situação do fato. ${ }^{109}$

\footnotetext{
105 BITENCOURT, Cezar Roberto. Op. cit., p. 391.

${ }^{106}$ Ibid. p. 392.

${ }^{107}$ BIERRENBACH, Sheila. Op. cit., p. 199.

${ }^{108}$ Ibid. p. 199.

109 JESUS, Damásio de. Op. cit., p. 509.
} 
No primeiro caso, se o sujeito supõe a existência de uma norma que, se existisse, tornaria legítima sua conduta, esta teoria afirma existir dolo, permitindo a absolvição do sujeito em caso de erro inevitável. Já no segundo caso, supondo o sujeito estar agindo acobertado por causa excludente da ilicitude, o dolo é eliminado, podendo responder por crime culposo. $^{110}$

Já a professora Sheila Bierrenbach afirma que a maioria da doutrina brasileira adotou o conceito de culpabilidade advinda do finalismo. Assim, a culpabilidade é considerada puramente normativa, devendo ser entendida como juízo de reprovação. ${ }^{111}$ A função do magistrado, sob a ótica desta tese, é a de questionar se o agente que praticou o injusto merece ou não ser reprovado pela sua ação.

Logo, em uma primeira fase, o juiz deve verificar se a conduta do agente se subsume ou não a um tipo penal previamente determinado em lei. Posteriormente, analisa a antijuridicidade, buscando analisar se há alguma excludente de ilicitude no caso em concreto. Após esses passos é que se observa o acusado como sujeito do delito, verificando se pode ser considerado culpável ou não. ${ }^{112}$

Portanto, após o estudo da evolução história da culpabilidade, entendidos os principais conceitos que permeiam este terceiro elemento do conceito analítico de crime, cumpre aprofundar o estudo em seu elemento mais importante: a imputabilidade penal.

Para que seja possível a responsabilidade penal de um indivíduo que supostamente preencheu todos os elementos do conceito analítico de crime, é preciso que o mesmo seja imputável. A imputabilidade é a possibilidade de atribuir o fato típico e ilícito ao agente. ${ }^{113}$

\footnotetext{
${ }^{110}$ Ibid. p. 509.

${ }^{111}$ BIERRENBACH, Sheila. Op. cit.. p. 200.

${ }^{112}$ Ibid. p. 200.

${ }^{113}$ GRECO, Rogerio. Op. cit.. p. 395.
} 
É entendida como a plena capacidade de entender e de que querer, sendo comumente definida como o "conjunto as condições de maturidade e sanidade mental que permitem ao agente conhecer o caráter ilícito do seu ato e determinar-se de acordo com esse entendimento". ${ }^{114}$

Diametralmente oposta, a imputabilidade é aplicada ao sujeito que "carece desta capacidade, por não ter maturidade suficiente, ou por sofrer graves alterações psíquicas" "115, não podendo, então, ser este agente declarado culpado pelos seus atos, ainda que sejam típicos e antijurídicos.

Portanto, a imputabilidade é a capacidade de entendimento da antijuridicidade do comportamento e de autogovernar-se de acordo com este conhecimento. ${ }^{116}$ Destaque-se, então, que tal capacidade possui dois aspectos, o intelectivo (capacidade de compreender a ilicitude do fato) e o volitivo (determinação da vontade a atuar conforme tal compreensão). ${ }^{117}$

Importante destacar que há diferença entre imputabilidade e responsabilidade penal. Enquanto a primeira se traduz na condição pessoal do agente, a segunda seria o dever jurídico de responder pela ação delituosa, que recai no agente imputável. ${ }^{118}$. A discussão quanto às possíveis diferenças entre estes dois conceitos se iniciou na década de 40, com o emprego do termo "responsabilidade penal" como sinônimo de imputabilidade pelo legislador penal. A reforma da parte geral em 1984 retirou o termo "responsabilidade", introduzindo então a imputabilidade. ${ }^{119}$

Há três sistemas de aferição da inimputabilidade destacados pela doutrina. O primeiro, chamado de sistema biológico, leva em consideração a doença mental e à anormalidade da mente. Foi primeiramente observado no Código Penal Francês de 1810, que preceituava que "não há crime nem

\footnotetext{
${ }^{114}$ PRADO, Luiz Régis apud ANÍBAL BRUNO. Op. cit., p. 390.

${ }^{115}$ BITENCOURT, Cezar Roberto apud MUÑOZ CONDE. Op. cit., p. 438

${ }^{116}$ FRAGOSO, Heleno Cláudio. Op. cit.. p. 242.

117 PRADO, Luiz Régis. Op. cit., p. 390.

118 FRAGOSO, Heleno Cláudio. Op. cit., p. 242.
} 
delito, quando o agente estiver em estado de demência ao tempo da ação". 120

O segundo sistema é denominado de psicológico, e considera apenas as condições psicológicas do agente à época dos fatos. Isto é, concentra-se apenas nas consequências psicológicas dos estados anormais do indivíduo. Foi observado no Código Canônico ("delicti sunt incapaces qui actu carent usu rationis") e adotado pelo Código Criminal do Império, em seu art. 10 ("Também não se julgarão criminosos: $\$ 2^{\circ}$ Os loucos de todo gênero, salvo se tiverem lúcidos intervallo e nelles commetterem o crime”) e pelos Códigos Penais da Áustria (1852), da Espanha (1848) e de Portugal $(1886){ }^{121}$

Por fim, o terceiro critério é o chamado biopsicológico, resultado da combinação dos anteriores. Nesse sentido, exige, por um lado, a presença de anomalias mentais e, por outro, a completa incapacidade de entendimento. Este sistema foi adotado pela maioria das atuais legislações penais, como o Código Penal Italiano, o Código Penal Espanhol de 1995, o Código Penal Alemão e o Código Penal Português. ${ }^{122}$

O Código Penal Brasileiro de 1940 adotou o sistema biopsicológico, determinando, em seus art. 26, os inimputáveis, conforme se depreende da leitura do dispositivo:

Art. 26 - É isento de pena o agente que, por doença mental ou desenvolvimento mental incompleto ou retardado, era, ao tempo da ação ou da omissão, inteiramente incapaz de entender o caráter ilícito do fato ou de determinar-se de acordo com esse entendimento.

\footnotetext{
${ }^{119}$ FUHRER, Maximiliano. Tratado da inimputabilidade no Direito Penal. São Paulo: Editora Malheiros, 2000. p. 38.

${ }^{120}$ PRADO, Luiz Régis. Op. cit., p. 390.

${ }^{121}$ Ibid. p. 390.

${ }^{122}$ Ibid. p. 390-391.
} 
Interessante notar que o legislador adotou a técnica de afirmação negativa, conceituando o que era inimputável para, inversamente, poder definir-se o imputável. Assim, pelo que se infere do diploma legal, nos leva a concluir a inimputabilidade do indivíduo a a) existência de uma doença mental ou desenvolvimento mental incompleto ou retardado e b) a absoluta incapacidade de, ao tempo da ação ou da omissão, entender o caráter ilícito do fato ou de determinar-se de acordo com esse entendimento.

\section{Cumpre transcrever trecho da Exposição de Motivos da Parte Geral} do Código Penal de $1940^{123}$, escrita pelo Min. Francisco Campos e levada à Comissão Revisora composta por Vieira Braga, Nelson Hungria, Narcélio de Queiroz e Roberto Lyra, que justifica a escolha deste sistema:

$\mathrm{Na}$ fixação do pressuposto da responsabilidade penal (baseada na capacidade de culpa moral) apresentam-se três sistemas: o biológico ou etiológico (sistema francês), o psicológico e o biopsicológico. O sistema biológico condiciona a responsabilidade à saúde mental, à normalidade da mente. Se o agente é portador de uma enfermidade ou grave deficiência mental, deve ser declarado irresponsável, sem necessidade de ulterior indagação psicológica. O método psicológico não indaga se há uma perturbação mental mórbida: declara a irresponsabilidade se, ao tempo do crime, estava abolida no agente, seja qual for a causa, a faculdade de apreciar a criminalidade do fato (momento intelectual) e de determinar-se de acordo com essa apreciação (momento volitivo). Finalmente, o método biopsicológico é a reunião dos dois primeiros: a responsabilidade só é excluída se o agente, em razão de enfermidade ou retardamento moral, era, no momento da ação, incapaz de entendimento ético-jurídico e autodeterminação.

O método biológico, que é inculcado pelos psiquiatras em geral, não merece adesão: admite aprioristicamente um nexo constante de causalidade entre o estado mental patológico do agente e o crime: coloca os juízes na absoluta dependência dos peritos médicos e, o que é mais, faz tabula rasa do caráter ético da responsabilidade. O método puramente psicológico é, por sua vez, inaceitável, porque não evita, na prática, um demasiado arbítrio judicial ou a possibilidade de um extensivo reconhecimento da irresponsabilidade, em antinomia com o interesse da defesa social. O critério mais aconselhável, de todos os pontos de vista, é, sem dúvida, o misto ou biopsicológico.

É o seguido pelo projeto (art. 22) ${ }^{124}$ : 'É isento de pena o agente que, por doença mental, ou desenvolvimento mental incompleto ou retardado, era, ao tempo da ação ou omissão, inteiramente incapaz de entender o caráter criminoso do fato, ou de determinar-se de acordo com esse entendimento'. No seio da Comissão foi proposto que se falasse, de modo genérico, em perturbação mental; mas a proposta foi rejeitada, argumentando-se, em favor da fórmula vencedora, que esta

\footnotetext{
${ }^{123}$ Note-se que o trecho escolhido é diferente da exposição de motivos da Nova Parte Geral inserida pela reforma penal de 1984 .

${ }^{124}$ Atual artigo 26 do Código Penal
} 
era mais compreensiva, pois, com a referência especial ao 'desenvolvimento mental incompleto ou retardado', e devendo entender-se como tal a própria falta de aquisições éticas (pois o termo 'mental' é relativo a todas as faculdades psíquicas, congênitas ou adquiridas, desde a memória à consciência, desde a inteligência à vontade, desde o raciocínio ao senso moral), dispensava alusão expressa aos surdos-mudos e silvícolas inadaptados.

Por doença mental, entendem-se todas as alterações mórbidas da saúde mental, qualquer que seja sua origem. Assim, se incluem não somente as psicoses como também as neuroses, embora estas dificilmente conduzam à completa incapacidade de entendimento ou de autodeterminação. $^{125}$

Desenvolvimento mental incompleto ou retardado caracteriza-se pelos indivíduos oligofrênicos, que apresentam anomalias do desenvolvimento mental. Nessa categoria incluía-se os surdos-mudos ("não-educados") e os silvícolas - atualmente discute-se se estes dois sujeitos poderiam ou não ser considerados inimputáveis. ${ }^{126}$ Somente uma perícia poderá comprovar a doença mental e o desenvolvimento incompleto ou retardado.

Comprovada a total inimputabilidade do agente, o magistrado deverá absolvê-lo, nos termos do art. 386, inciso V do Código de Processo Penal (a chamada "absolvição imprópria"), aplicando-lhe, por conseguinte, uma medida de segurança. Importante destacar que o ordenamento jurídico aplica o sistema vicariante (ao contrário do duplo binário), vedando a possibilidade de cumular pena e medida de segurança.

As medidas de segurança estão previstas nos arts. 96 e 97 do Código Penal, podendo ser de internação ou tratamento ambulatorial. A internação terá tempo indeterminado ${ }^{127}$, sendo certo que o mínimo de internação será

\footnotetext{
${ }^{125}$ PRADO, Luiz Régis. Op. cit., p. 246.

${ }^{126}$ Ibid. p. 246.

${ }^{127}$ Atualmente já há entendimento no sentido de que o tempo máximo possível é de 30 anos, em paralelismo ao tempo máximo possível que o indivíduo pode cumprir pena privativa de liberdade. Por esta posição, encontra-se o STF: "1. A prescrição da medida de segurança deve ser calculada pelo máximo da pena cominada ao delito cometido pelo agente, ocorrendo o marco interruptivo do prazo pelo início do cumprimento daquela, sendo certo que deve perdurar enquanto não haja
} 
de um a três anos. A lei prevê, nos casos de medida de segurança, a proteção da sociedade em face de um indivíduo considerado perigoso. A periculosidade do agente é que vai determinar o tratamento adequado, a fim de que tal perigo seja tratado (e não punido).

O parágrafo único do artigo 26 do $\mathrm{CP}$ prevê ainda que a "pena pode ser reduzida de um a dois terços, se o agente, em virtude de perturbação de saúde mental ou por desenvolvimento mental incompleto ou retardado não era inteiramente capaz de entender o caráter ilícito do fato ou de determinar-se de acordo com esse entendimento." Neste caso estamos diante de uma semi-imputabilidade, em que o juiz deverá aplicar pena reduzida ou, entendo não ser esta adequada, aplicar uma medida de segurança.

Ressalte-se que, neste último caso, o legislador optou por falar em "perturbação mental", e não em doença mental ou desenvolvimento mental incompleto. Ou seja, quis abarcar as hipóteses nas quais há certa enfermidade mental, mas que esta não afastou por completo a plena capacidade de entendimento e autodeterminação, apenas reduzindo a possibilidade de conhecimento do caráter ilícito e de agir conforme tal apreensão.

A inimputabilidade também foi prevista no art. 27 do $\mathrm{CP}$, que dispôs que os "menores de 18 (dezoito) anos são penalmente inimputáveis, ficando sujeitos às normas estabelecidas na legislação especial.”. A eleição de idade pelo legislador se deu, por política criminal, pela imaturidade natural inerente aos menores de 18 anos, pressupondo que os mesmos não possuem plena capacidade de entendimento que lhes permita imputar um fato típico e ilícito. Neste caso, adotou-se apenas o critério biológico. ${ }^{128}$

cessado a periculosidade do agente, limitada, contudo, ao período máximo de 30 (trinta) anos, conforme a jurisprudência pacificada do STF." (STF, RHC 100383 / AP , Rel. Min. Luiz Fux, j. em 18.10.2011).

${ }^{128}$ BITENCOURT, Cezar Roberto. Op. cit., p. 399. 
Por fim, outra causa que exclui a imputabilidade é a embriaguez acidental completa, prevista no art. 28 , inciso II, $\S 1^{\circ}$ do $\mathrm{CP}^{129}$ e a embriaguez patológica completa. Esta seria a única hipótese em que se atribui alguma relevância à embriaguez. É preciso que ela conduza o agente a um estado em que esteja inteiramente incapaz de entender o caráter criminoso do fato e de guiar-se por tal entendimento. ${ }^{130}$

Outro ponto importante acerca da inimputabilidade do agente é que esta deve estar presente ao tempo da prática do fato, inexistindo a possibilidade de uma inimputabilidade subsequente. ${ }^{131}$ Caso o agente se coloque em situação de inimputabilidade para cometer algum crime (p. ex, se embriaga voluntariamente para realizar algum delito), é discutível se pode ser ou não considerado imputável.

A teoria da actio libera in causa trata exatamente dos casos de conduta livremente desejada, mas cometida no instante em que o sujeito se encontra em estado de inimputabilidade, isto é, no momento da prática do delito o agente não possui capacidade de querer e entender. Teria havido, assim, liberdade originária, mas não liberdade atual (no momento do cometimento do fato). ${ }^{132}$

Esta tese atualmente é definida como compreendendo os casos em que "alguém no estado de não-imputabilidade é causador, por ação ou omissão, de um resultado punível, tendo se colocado naquele estado, ou propositadamente, com a intenção de produzir o evento lesivo, ou sem essa intenção, mas tendo previsto a possibilidade de resultado, ou, ainda, quando podia e devia prever". 133

\footnotetext{
129 “É isento de pena o agente que, por embriaguez completa, proveniente de caso fortuito ou força maior, era, ao tempo da ação ou da omissão, inteiramente incapaz de entender o caráter ilícito do fato ou de determinar-se de acordo com esse entendimento".

${ }^{130}$ FRAGOSO, Heleno Cláudio. Op. cit., p. 247.

${ }^{131}$ JESUS, Damásio de. Op. cit.,. p. 516.

${ }^{132}$ Ibid. p. 516.

${ }^{133}$ PRADO, Luiz Régis apud QUEIROZ Narcélio. Op. cit.,. p. 393.
} 
Assim, através desta teoria, analisa-se a conduta do agente no momento em que se iniciou o consumo da substância entorpecente (p. ex. no caso de embriaguez preordenada). É nesse momento que se deve observar a imputabilidade do sujeito, podendo, então, ocorrer três hipóteses.

Em um primeiro cenário, o indivíduo embriagou-se com a finalidade de cometer um delito. Responderá pelo crime doloso, com a incidência da agravante prevista no art. 61, inciso II, "l” do CP. Outra situação seria a do sujeito que se embriaga voluntariamente e acaba cometendo um crime. Nesse caso, responderá na modalidade culposa do delito. Por fim, o agente embriaga-se culposamente e comete um crime. Analisando a previsibilidade no caso concreto, poderá também responder pelo delito na modalidade culposa. $^{134}$.

Há, ainda, além da imputabilidade, outros elementos importantes que compõem a culpabilidade. Porém, cumpre destacar que o presente trabalho se concentrou mais no elemento imputabilidade, já que posteriormente o mesmo será aplicado às questões dos psicopatas.

A potencial consciência de ilicitude é outro componente importante, constituído pela possibilidade de o agente conhecer o caráter ilícito de sua ação, sendo tal conhecimento potencial, e não real, da ilicitude. ${ }^{135}$

Este conhecimento não se refere às leis penais, mas apenas que o agente saiba ou tenha podido saber que seu comportamento contraria o ordenamento jurídico. É o conhecimento da antijuridicidade da ação. A ausência de tal consciência dá lugar ao erro de proibição, previsto no art. 21 do $\mathrm{CP}$, que, sendo inevitável, torna-se causa excludente de culpabilidade. ${ }^{136}$

\footnotetext{
${ }^{134}$ BIERRENBACH, Sheila. Op. cit., p. 218-219.

${ }^{135}$ PRADO, Luiz Régis. Op. cit., 393.

${ }^{136}$ Ibid. p. 393-394.
} 
Um terceiro elemento da culpabilidade é a exigibilidade de conduta diversa. Neste ponto, trata-se de elemento volitivo de reprovabilidade, que consiste na exigibilidade de obediência à norma. Para que a ação possa ser considerada reprovável, é necessário que se possa exigir comportamento contrário ao que se teve. ${ }^{137}$

Assim como a imputabilidade e o potencial conhecimento da ilicitude, a exigibilidade de conduta diversa também possui excludentes, quais sejam, a inexigibilidade de conduta diversa, a coação irresistível e a obediência hierárquica.

A coação irresistível e obediência hierárquica estão previstas no art. 22 do Código Penal, sendo causas legais de exclusão de culpabilidade. A primeira hipótese consiste em coação moral de um agente sobre outro a cumprir determinado mal. No segundo cenário, aplicado apenas a entes de Direito Público, o subordinado cumpre ordem não manifestamente ilegal. Nestas duas hipóteses o sujeito deve ser absolvido. ${ }^{138}$

Já a própria inexigibilidade de conduta diversa é uma causa supralegal de exclusão da culpabilidade, e consiste na possibilidade de observar no caso concreto a impossibilidade de o agente agir de outra forma que não a realizada. ${ }^{139}$

Portanto, conforme pudemos explicitar e discorrer, o conceito de crime mais compatível com a atualidade jurídica é o analítico, que se divide em tipicidade, antijuridicidade e culpabilidade. Expostos os três elementos componentes, em especial atenção vimos a culpabilidade e sua elementar imputabilidade, capaz de determinar se um agente, ao praticar um crime, deve ou não ser punido com sanção por ser capaz de determinar-se pelo seu entendimento do fato típico.

\footnotetext{
${ }^{137}$ Ibid. p. 394.

${ }^{138}$ BIERRENBACH, Sheila. Op. cit.,. p. 231-234.

${ }^{139}$ Ibid. p. 236.
} 
Tais conceitos são essenciais para que se possa aplicar ao caso dos psicopatas, em que muito se discutirá sobre doença mental e perturbações mentais, verificando a possibilidade ou não destes sujeitos serem considerados inimputáveis e a melhor resposta que o Direito Penal poderia dar a estes casos. 


\section{CAPÍTULO 2 - O CONCEITO DE PSICOPATIA}

\section{1 - Breve histórico e conceito}

"Ted pode ser descrito como o filho perfeito, o estudante perfeito, o escoteiro que virou adulto, um gênio, belo como um ídolo de cinema, uma luz brilhante para o futuro do partido Republicano, um sensível assistente social psiquiátrico, um precoce advogado, um amigo de confiança, um jovem com um futuro de sucesso. Ele era tudo isso, e nada disso. Ted Bundy não tinha um padrão; você não poderia olhar seu perfil e dizer "viu, era inevitável que ele iria acabar assim". ${ }^{140}$

Quando pensamos em psicopata, é comum vir à mente personagens famosos, como as figuras de Hannibal Lecter de "O silêncio dos inocentes", ou então Adolf Hitler e Saddam Hussein, ou ainda Ted Bundy, Jeffrey Dahmer e Charles Manson, famosos criminosos norte-americanos. Não há como negar que todos estes indivíduos personalizaram o mal, com atitudes criminosas, bizarras e grosseiras. Entretanto, não se pode levianamente atribuir a eles a alcunha de psicopatas, como sinônimo de assassinos frios, seriais ou lunáticos.

A psicopatia abrange muito mais do que as imagens sensacionalistas criadas pela mídia. O uso incorreto e indiscriminado do termo "psicopatia" em filmes, literatura e meios de comunicação busca apenas atrair aqueles que gostam de morbidez e tenta despertar a curiosidade da sociedade. ${ }^{141} \mathrm{~A}$ problemática gerada por conta da midiatização da psicopatia faz com que muitos pensem que os psicopatas são apenas assassinos seriais, ou outro tipo de criminoso desalmado e cruel $^{142}$.

\footnotetext{
${ }^{140}$ RULE, Ann. The stranger beside me - prefácio. Nova York: W. W. Norton and Company, 1981. p. 15.

O livro foi escrito por uma colega de trabalho de Ted Bundy, famoso serial killer norte-americano que, em tese, parece apresentar todos os requisitos de um psicopata. Tradução livre.

${ }^{141}$ SÁNCHEZ GARRIDO, Francisco José. Fisonomia de la psicopatia. Concepto, origem, causas y tratamiento legal. $3^{a}$ Época. n. 2. Madrid: Revista de Derecho Penal y Criminologia. p. 84-85.

${ }_{142}$ Ibid, p. 85.
} 
Livros vendidos como best-sellers atraem a atenção do povo, tentando "ensinar" a encontrar e caracterizar um psicopata, deixando implícito que até o vizinho do leitor pode ser um. Por óbvio, é preciso um estudo acurado do tema, para que se possa definir um psicopata, como se verá adiante.

Analisando historicamente, já nos idos do século IV a V a.C, o pensador grego Hipócrates estudou possíveis transtornos mentais que se originavam no próprio organismo do ser humano. Foi o pioneiro a tratar da hoje chamada "teoria dos quatro humores corporais" (considerando tais humores - que se subdividam em bílis negra, bílis amarela, fleuma e sangue ou linfa - os elementos que determinavam os comportamentos pessoais. A bílis amarela, por exemplo, era característico dos sujeitos dominadores e violentos). ${ }^{143}$

Teofrasto, aluno de Aristóteles, também estudou as principais características da psicopatia, elencando alguns sintomas do chamado "homem inescrupuloso" (e algumas características descritas pelo filósofo incorporam o conceito atual de psicopata, como a loquacidade e boa lábia). ${ }^{144}$ No século II, o médico grego Cláudius Galeno sustentou a existência de quatro temperamentos que determinavam as características das pessoas, com base nos humores classificados por Hipócrates (por exemplo, o temperamento "colérico-bílis amarilla" era comum aos homens violentos). ${ }^{145}$

\footnotetext{
${ }^{143}$ Ibid. p. 90.

${ }^{144}$ MILLON, Theodore; SIMONSEN, Erik; BIRKET-SMITH, Morten. In: Historical conceptions of psychopathy in the United States and Europe - Psychopathy: antisocial, criminal and violent behavior. Nova York: The Guilford Press, 1998. p. 3.

${ }^{145}$ SÁNCHEZ GARRIDO, Francisco José. Op. cit., p. 91.
} 
O termo "psicopata" foi utilizado, inicialmente, para designar uma série de comportamentos que eram vistos como moralmente repugnantes. ${ }^{146}$ A discussão efetiva acerca da psicopatia se iniciou ao fim do séc. XVIII, quando alguns filósofos e psiquiatras passaram a estudar a relação de livre arbítrio e transgressões morais, questionando se alguns perpetradores seriam capazes de entender a consequência de seus atos. Interessante notar que até o período do Iluminismo, acreditava-se que os crimes cometidos por psicopatas eram obras do diabo (já que, naquela época, entendia-se que esta figura bíblica encarnava a perversão, o egoísmo, a maldade e a violência). ${ }^{147}$

Philippe Pinel, em 1801, foi o primeiro a notar que certos pacientes, envolvidos em atos impulsivos e autodestrutivos, tinham sua habilidade de raciocínio intacta e tinham consciência da irracionalidade do que estavam fazendo. A estes casos, ele denominou serem "manie sans delire", ou insanidade sem delírio. ${ }^{148}$ Nesta época, como era entendido que "mente" era sinônimo de "razão", qualquer inabilidade racional ou de intelecto era considerada insanidade, uma doença mental. Foi com Pinel que surgiu a possibilidade de existir um indivíduo insano (manie), mas sem qualquer confusão mental (sans delire).

Esquirol, como discípulo de Pinel, continua os estudos de seu tutor e denomina a acepção da "monomania impulsiva" para determinar a psicopatia. ${ }^{149}$ Pouco tempo após a manifestação de Pinel e de Esquirol, em 1812, Benjamin Ruesch descreveu a personalidade de pessoas que cometiam atos antissociais desde muito cedo, ainda na infância,

\footnotetext{
${ }^{146}$ MILLON, Theodore; SIMONSEN, Erik; BIRKET-SMITH, Morten. In: Historical conceptions of psychopathy in the United States and Europe - Psychopathy: antisocial, criminal and violent behavior. Nova York: The Guilford Press, 1998. p. 3.

${ }^{147}$ SÁNCHEZ GARRIDO, Francisco José. Op. cit., p. 91.

${ }^{148}$ MILLON, Theodore et al., Op. cit., p. 4.

${ }^{149}$ SÁNCHEZ GARRIDO, Francisco José. Op. cit., p. 92.
} 
designando-os como portadores de "idiotez moral" ou "imbecilidade moral". 150

Em 1835, em "A treatise on insanity and other disorders affecting the mind" o britânico J. C. Prichard aceitou a teoria de Pinel acerca do "manie sans delire"; entretanto, dissentiu sobre a moralidade neutra deste transtorno (a qual Pinel acreditava), tornando-se um dos expoentes a crer que tais comportamentos significavam um repreensível defeito de caráter, que merecia condenação social. Além disso, ele abrangiu o escopo da "síndrome" original, criando o rótulo "insanidade moral", incluindo, então, uma vasta gama de outras condições mentais e emocionais.

O autor define como "loucura moral" uma perversão mórbida dos sentimentos naturais, dos afetos, das inclinações, do temperamento, dos hábitos, das disposições morais e dos impulsos naturais, sem que apareça nenhum transtorno ou defeito destacável na inteligência, ou nas faculdades de conhecimento e raciocínio e, particularmente, sem a presença de alucinações e ilusões. Para Prichard, então, loucos morais são os criminosos e as pessoas pouco decentes, carentes de sentimentos e de sentido ético. ${ }^{151}$

Assim, por este entendimento, Prichard acreditava que todos estes pacientes compartilhavam um defeito no poder de se guiar de acordo com os "sentimentos naturais", isto é, um intrínseco e espontâneo senso de retidão, bondade e responsabilidade. Aqueles que tinham tal condição eram seduzidos, apesar de suas habilidades de entender suas escolhas, por um "sentimento superpoderoso", que os conduzia a praticar atos socialmente repugnantes, como, por exemplo, crimes. ${ }^{152}$ Observou, portanto, a carência de sentimentos, a falta de autodomínio e ausência de todo sentimento ético

\footnotetext{
${ }^{150}$ ZARLENGA, Marcelo E. El psicópata perverso en la jurisprudencia argentina: una primeira aproximación. v. 6, 10 ${ }^{\mathrm{a}}$ ed. Buenos Aires: Cuadernos de Doctrina y Jurisprudencia Penal, 2000. p. 480-481.

${ }^{151}$ SÁNCHEZ GARRIDO, Francisco José. Op. cit., p. 92.

${ }^{152}$ MILLON, Theodore et al., Op. cit., p. 5-6.
} 
de alguns de seus pacientes, determinando, então, os principais traços destas personalidades. ${ }^{153}$

Henry Maudsley, em contraste à teoria de Prichard, argüiu que existiria uma parte específica do cérebro em que haveria os "sentimentos morais naturais". A esta construção de que déficits cerebrais nesta referida área seriam justificativas para os moralmente depravados, foram adicionadas abordagens antropológicas trazidas por Lombroso e Gouster. Cesare. Lombroso afirmava a existência do criminoso nato, ou seja, aquele indivíduo que nascia com certas características físicas (como ser canhoto, ter uma testa proeminente, ser sexualmente desenvolvido precocemente, etc.) que indicariam grandes chances de que viesse a cometer algum delito em sua vida. M. Gouster, por sua vez, trouxe características psicológicas que conduziriam um indivíduo a cometer crime, como por exemplo, perversão moral precoce, desobediência, mentiras, irascibilidade, etc. ${ }^{154}$

Ainda no século XIX, outros exemplos de estudo sobre a psicopatia foram realizados. Próspero Despine, médico filósofo, publicou a obra "Psychologie naturelle", em 1868, na qual destacou a anomalia psíquica de certos delinquientes carentes de senso moral. Em 1870, Kraft Ebing vinculou os estados denomidados "psicopáticos" com os de degeneração, mesmo ano em que outro autor, Kandinsky, sustentou que a psicopatia começaria nos primeiros anos dos indivíduos. ${ }^{155}$

Na metade do século XIX, a chamada "escola francesa" considerou o psicopata como uma pessoa desequilibrada. Auguste Morel, expoente desse pensamento, chegou a se manifestar no sentido da presença da loucura dos degenerados, determinando o conceito de "mania instintiva" em relação a tal degeneração. ${ }^{156}$

\footnotetext{
${ }^{153}$ ZARLENGA, Marcelo E. Op. cit., p. 485.

${ }^{154}$ MILLON, Theodore et al., Op. cit., p. 7.

${ }^{155}$ ZARLENGA, Marcelo E. Op. cit., p. 485.

${ }^{156}$ SÁNCHEZ GARRIDO, Francisco José. Op. cit., p. 92.
} 
Ainda neste período, o alemão J. Koch distinguiu os elementos diferenciadores das psicoses e da psicopatia. Agrupa, então, diversas entidades (que ele denomina como sentimentos lacrimosos, os sonhadores, os caprichosos, os exaltados, etc.) e as caracteriza como "inferioridade psicopáticas". 157

Já em 1904, Emile Kraepelin identificou quatro tipos de pessoas que possuiriam a chamada "personalidade psicopática", 158 já que, por suas características, seriam associadas a comportamentos antissociais. O primeiro tipo eram os mentirosos e vigaristas mórbidos, caracterizados como lisonjeiros e encantadores, mas desprovidos de uma moralidade interna e responsabilidade com outros (eram, em sua maioria, os fraudadores).

O segundo grupo eram os criminosos por impulso, aqueles envolvidos em crimes como roubo, furto, incêndio, e que não podiam controlar suas vontades. O terceiro tipo seria constituído pelos criminosos profissionais, que tinham boas maneiras e eram socialmente aprovados, mas na verdade eram manipuladores e egocêntricos. Por fim, o último grupo era o dos vagabundos mórbidos, que levavam a vida na vadiagem e sem responsabilidades. $^{159}$

Por sua vez, K. Birnbaum, em 1909, sugeriu o termo "sociopatia" como o mais apto a designar estes casos. Para o autor, nem todos os delinquientes tinham defeitos morais ou eram naturalmente constituídos para serem criminosos, mas sim eram fruto do ambiente social em que estavam inseridos. Neste ponto, apesar de muitos utilizarem sociopatia como sinônimo de psicopatia (por serem distúrbios antissociais e compartilharem características semelhantes), é importante destacar que atualmente não há que se confundir tais termos, exatamente porque o primeiro envolve

\footnotetext{
${ }^{157}$ Ibid, p. 93.

158 Ibid, pag. 93.

${ }^{159}$ MILLON, Theodore et al., Op. cit., p. 10.
} 
atributos adquiridos em razão das circunstâncias sociais em que o sujeito está inserido enquanto o segundo é característica nata do indivíduo.

Em 1924, Eugene Bleuler tornou-se o primeiro psiquiatra a utilizar, em seu "Tratado de Psiquiatria", o conceito de psicopatia, atribuindo-lhe o significado de defeito moral congênito ou adquirido. A Escola Psicoanalítica de Freud qualificará este transtorno, por sua vez, como "neurose de caráter". 160

Kurt Schneider propôs, em sua obra "As personalidades psicopáticas" um conceito e uma classificação importante sobre psicopatia. Para ele, as personalidades psicopáticas seriam aquelas que sofrem por sua anormalidade e fazem sofrer, por conta delas, toda a sociedade. Passa a elencar, então, dez tipos diferentes ${ }^{161}$ destas personalidades, determinando, como critério fundamental para a psicopatia, a total ausência de transtorno mental. $^{162}$

Hervey Cleckley, em 1941, tornou-se inegavelmente o principal autor a escrever sobre a psicopatia, com o livro "The mask of sanity". Tentando esclarecer o termo "transtorno de personalidade antissocial" e outras terminologias problemáticas, Cleckley propõe substituir o termo mencionado e colocar o caso sob o rótulo de "demência semântica", para evidenciar o que ele via de mais importante nesta síndrome: a tendência de dizer uma coisa e fazer outra. ${ }^{163}$ Além disso, nesse livro, Cleckley esclarece que os psicopatas não são necessariamente criminosos. São indivíduos que possuem determinadas características (falta de sentimento de culpa, impulsividade, emoções superficiais, charme superficial, etc.), podendo ser homens de negócio, cientistas, físicos e até um psiquiatra.

\footnotetext{
${ }^{160}$ SÁNCHEZ GARRIDO, Francisco José. Op. cit., p. 93.

${ }^{161}$ Para ele, as personalidades psicopáticas são: hipertímicos, depressivos, inseguros de si mesmo, fanáticos, necessitados de estímulos, boa lábia, explosivos, desalmados, apáticos e astênicos.

${ }^{162}$ SÁNCHEZ GARRIDO, Francisco José. Op. cit., p. 94.

${ }^{163}$ MILLON, Theodore et al., Op. cit., p. 18.
} 
Contemporâneo a Cleckley, o psicólogo Californiano H. G. Gough caracteriza os psicopatas por uma sobrevaloração dos objetivos imediatos em face dos objetivos remotos ou futuros; despreocupação pelos direitos e privilégios de outros; comportamento impulsivo; incapacidade de criar vínculos profundos e constante com outras pessoas ou para identificar-se em relações interpessoais; falta de planejamento para conseguir determinados objetivos; aparente falta de ansiedade e de sofrimento pela sua inadaptação social e sua negativa de reconhecimento de tal inadaptação; tendência a projetar nos outros as culpas e não aceitar a responsabilidade por seus próprios fracassos; mentiras; falta de responsabilidade e pobreza emocional. ${ }^{164}$ Em síntese, propõe características similares às descritas por Cleckley em seu livro, que será posteriormente abordado com mais profundidade.

Em 1944 dois momentos importantes para a psicopatia podem ser destacados. Em primeiro lugar, os psiquiatras Curran e Mallinson chegaram a afirmar que a psicopatia era doença mental. ${ }^{165}$ Entretanto, conforme pode se observar historicamente, a psicopatia não deve ser considerada uma doença mental como a esquizofrenia ou transtorno bipolar ${ }^{166}$. O indivíduo considerado psicopata não tem alucinações, psicose ou neurose ${ }^{167}$; ele tem plenas capacidades mentais, mas, por sua vez, possui determinadas

\footnotetext{
${ }^{164}$ SÁNCHEZ GARRIDO, Francisco José. Op. cit., p. 95.

165 HUSS, MATTHEW T. Psicologia Forense. $1^{a}$ ed. Porto Alegre: Editora Artmed, 2011. p. 91.

${ }^{166}$ SÁNCHEZ GARRIDO, Francisco José. Op. cit., p. 116.

GARRIDO traz algumas diferenças essenciais entre a Psicopatia e algumas doenças efetivamente mentais: i) Psicopatia vs Neurose - o neurótico é consciente de que padece de uma enfermidade e sofre por isso, enquanto o psicopata não sofre por sua condição, nem manifesta a ansiedade e a angústia que a neurose demonstra; ii) Psicopatia vs psicose - a psicose é uma enfermidade mental que acarreta na perda de contato com a realidade e a quebra da própria identidade do paciente. É acompanhada de delírios, alucinações, mudanças profundas de humor e transtornos de condutas severos (enquanto a psicopatia não apresenta nenhuma destas características); iii) Psicopatia vs paranoia - não há nada de similar entre o delírio crônico do paranóico com a manipulação da realidade feita pelos psicopatas; iv) Psicopatia vs Esquizofrenia - O psicopata está livre das alucinações e delírios que caracterizam as esquizofrenias; v) Psicopatia vs narcisismo - os psicopatas certamente são narcisistas, no que tange a impulsividade, a destrutividade e o induzimento a erro. Entretanto, poucos narcisistas têm um histórico delitivo e antissocial como os psicopatas; vi) Psicopatas vs TAP - o transtorno antissocial de personalidade somente têm em comum com a psicopatia os aspectos que dizem respeito às condutas, não possuindo as características interpessoais falhas que possuem os psicopatas.
} 
características cerebrais que o diferencia da normalidade. ${ }^{168}$ Em segundo, o psicoanalista Robert Lindner publicou seu livro "Rebel without case", descrevendo o psicopata como um rebelde, um desobediente fanático. Sua rebeldia estaria dirigida a alcançar a satisfação de seus próprios objetivos, sendo incapaz de realizar algo em benefício de outra pessoa. ${ }^{169}$

A década de 50 também trouxe novos avanços sobre o estudo da psicopatia. Em 1956, a denominada “escola norte-americana”, liderada pelos McCord, destacou a influência do meio para a configuração da personalidade psicopata. Por essa linha de pensamento, se difundiu a denominação "sociopata", já mencionada anteriormente por Birnbaum. ${ }^{170}$ Os McCord ressaltavam, entre outros aspectos, a incapacidade do psicopata em formar vínculos de afeto duradouros com outras pessoas e reações agressivas predominantes. Em 1958, Ackerman assinala que os psicopatas têm deformidades no processo de identificação com o outro. É egocêntrico, dominador e onipotente. Posição similar adotou Lindner, em 1959. ${ }^{171}$

Em 1960 três posições acerca do conceito de psicopatia são formadas, que, ao fim, acabam por se complementar. A primeira, defendida por Stone e Church, se refere a uma "delinqüência psicopática", isto é, o indivíduo é incapaz de ter verdadeiros sentimentos pelos demais, e carece de ligações emocionais fortes com a realidade. A segunda, proposta por Henry Ey, destaca, junto com a inadaptação social, a facilidade com que os psicopatas agem, principalmente quanto aos crimes cometidos. Por fim, Sullivan ressalta a instabilidade do psicopata quanto ao estabelecimento de relações interpessoais. ${ }^{172}$

\footnotetext{
${ }^{167}$ CLECKLEY, Hervey. The mask of sanity - 5 ed. - "scanned facsimile produced for non-profit educational use" http://cassiopaea.org/cass/sanity $1 . \mathrm{PdF}$ acesso em 9 de julho de 2011

${ }_{168}$ O Parecer CREMERJ n. 05 de 1990 reafirma a posição de que a psicopatia não é doença mental, classificando-a entre os transtornos da estrutura da personalidade.

${ }^{169}$ SÁNCHEZ GARRIDO, Francisco José. Op. cit., p. 96.

${ }^{170}$ ZARLENGA, Marcelo E. Op. cit., p. 508.

${ }^{171}$ Ibid. p. 508.

${ }^{172}$ Ibid. p. 508.
} 
Um estudo aprofundado de psiquiatria demonstra que psicopata apresenta um id deformado, desarmônico, escasso de unicidade, com importantes dificuldades para programar a vida, dotá-la de um sentido e uma continuidade biográfica, com pouca aptidão para ligar a energia pulsional com representação de palavras, formar símbolos e tramitar por esta via de tensão intrapsíquica, que se torna infrutífera e tende a ser descarregada mediante atos (podendo ser criminosos). ${ }^{173}$

O conceito de psicopatia, como se pode observar pelas diversas definições trazidas ao longo do tempo, não é uniforme. Há quem diga existir quatro acepções atualmente: i) Lato sensu, que seria qualquer transtorno, o que antes era chamado de loucura ou insanidade. Este é o sentido que é dado por A. Porot em seu "Manuel alphabétique", P. Marchais em "Glossaire de psychiatrie”, J. A. Brussel e G. L. Cantzlaar em "Diccionario de psiquiatria" e M. Ossorio em "Diccionario de ciências jurídicas"; ii) Enfermidade degenerativa hereditária, de grau leve, mas que pode dar lugar a estados de insanidade. São as "constituições psicopatas" de Dupré, os temperamentos ciclóides, esquizóide de Kretschmet e algumas das "psicosis mitis" de Marco Merenciano; iii) Personalidades anormais que sofrem por suas anormalidades ou fazem sofrer pela sociedade. Segundo Schneider, se trata de uma delimitação arbitraria, que se funda exclusivamente em razões práticas. iv) Transtorno mental centrado especificamente pela atuação. Este é o conceito psicodinâmico e se refere ao caráter. ${ }^{174}$

Apesar das diversas discussões, certo é que a psicopatia não deve ser reduzida a mero transtorno de personalidade antissocial, o que é comumente afirmado. Há uma errada tendência, principalmente após o surgimento das Classificações Internacionais das Enfermidades Mentais DSM-IV-TR e

\footnotetext{
${ }^{173}$ SÁNCHEZ CORRAL, José Manuel. La teoria del bem jurídico em el derecho penal liberal: contornos y protecciones a partir de uma concepcion personalista. Psicopatas e delincuentes Estudio Psiquiatrico. Diagnostico diferencial. n.1. Buenos Aires: Revista de Derecho Penal. p. 220.
} 
CIE-10 (que determinam os critérios de diagnóstico de Transtorno Antissocial da Personalidade [TAP] e Transtorno Dissocial da Personalidade [TDP]), em equiparar a Psicopatia a um destes tipos de transtornos. $^{175}$ Normalmente, os psicopatas também compartilham características que determinam este transtorno, mas isso não quer dizer que quem possui transtorno de personalidade antissocial é, consequentemente, psicopata.

O critério de diagnóstico utilizado para detectar estes transtornos, como acima mostrado, é o denominado "Diagnostic and statistical manual of mental disorder" ou "DSM". Foi criado pela Associação Americana de Psiquiatria em 1952, sendo aperfeiçoado ao longo do tempo. ${ }^{176} \mathrm{O}$ atual DSM-IV-TR preceitua que o sujeito poderá ser diagnosticado com transtorno de personalidade antissocial se apresentar, no mínimo, três dos seguintes critérios, a partir dos 15 anos de idade:

a) Incapacidade de se adequar às normas sociais com relação a comportamentos lícitos, indicada pela execução repetida de atos que constituem motivos de detenção;

b) Propensão para enganar, indicada por mentir repetidamente, utilizar nomes falsos ou ludibriar os outros, para obter vantagens físicas ou prazer;

c) Impulsividade ou fracasso em fazer planos para o futuro;

d) Irritabilidade e agressividade, indicadas por repetidas lutas corporais ou agressões físicas;

e) Desrespeito irresponsável pela segurança própria ou alheia;

\footnotetext{
${ }^{174}$ LÓPEZ BOLADO, Jorge Daniel. La inimputabilidad del psicopata - Doctrina Penal: Teoria y pratica em las ciências penales. v. 9, 33/36. Buenos Aires. p. 498.

${ }^{175}$ SÁNCHEZ GARRIDO, Francisco José. Op. cit., p. 85.

${ }^{176}$ LYKKEN, David T. In: Psychopathic personality: the scope of the problem. Handbook of Psychopathy. Nova York: The Guilford Press, 2006. p. 3.
} 
f) Irresponsabilidade consistente, indicada por um constante fracasso em manter um comportamento laboral consistente ou em honrar obrigações financeiras; e

g) Ausência de remorso, indicada pela indiferença ou racionalização por ter ferido, maltratado ou roubado alguém. ${ }^{177}$

Desta forma, apesar do DSM elencar algumas características semelhantes e/ou iguais a dos psicopatas (como se verá adiante), a psicopatia não é sinônimo de transtorno de personalidade antissocial, mas sim é conceituada como uma constelação de distintos traços da personalidade, sendo um constructo separado que enfatiza mais os traços afetivos e interpessoais. ${ }^{178}$ Assim, 90\% dos psicopatas sofrem do transtorno, mas apenas $15 \%$ a $30 \%$ daqueles que sofrem com o TPA são psicopatas. ${ }^{179}$

Por fim, há recentes estudos, ainda em fase inicial, que afirmam existir relação entre genética e psicopatia. Analisando crianças de até sete anos, em fase escolar, um estudo demonstrou que aqueles que têm comportamentos antissociais e que possivelmente podem vir a ser diagnosticados como psicopatas, certamente agem por influência genética. Isso porque, até tal idade, há poucos estímulos do meio-ambiente e da sociedade em geral que possam influenciar as atitudes dessas crianças. ${ }^{180}$

Assim tal como acontece com outras diferenças individuais, a psicopatia teria um componente substancial hereditário de cerca de $50 \%$. A pesquisa genética comportamental tem afirmado que as influências genéticas contribuem para as diferentes características de psicopatia. Além

\footnotetext{
${ }^{177}$ HUSS, MATTHEW T. Op. cit., p. 92.

${ }^{178}$ EDENS, John F.; LILIENFELD, Scott O.; MARCUS, David K.; POYTHRESS JR, Norman G.; Psychopathic, Not Psychopath: Taxometric Evidence for the Dimensional Structure of Psychopathy. v. 115. no. 1. Journal of Abnormal Psychology, 2006. p. 131-144.

${ }^{179}$ HUSS, MATTHEW T. Op. cit., p. 97.

180 VIDING, Essi.; BLAIR, R. James.; MOFFITT, Terrie.; PLOMIM, Robert. Evidence for substantial genetic risk for psychopathy in 7-year-olds. Journal of Child Psychology and Psychiatry 46:6, 2005. p. 95.
} 
disso, foi descoberto que as diferentes facetas da psicopatia variam conjuntamente com um fator global de psicopatia latente, que também é influenciado pelos genes. ${ }^{181}$

\section{2 - Características}

Psicopatia é, tal como demonstrada pelos estudos abordados, um tipo de personalidade que tem como principais características a falta acentuada de culpa, remorso e preocupação empática com os outros. Psicopatas parecem carecer de emoções, não se importando com o sofrimento alheio. Além disso, eles são superficialmente encantadores, manipuladores, egocêntricos e têm um senso de grandiosidade exacerbado. Tendem a ser impulsivos, costumam assumir riscos e não planejar o futuro. Como já mencionado, eles demonstram ter um comportamento antissocial e tem um controle comportamental muito pouco desenvolvido. ${ }^{182}$

Cleckley foi um dos primeiros pesquisadores a apresentar uma concepção definitiva e abrangente da psicopatia, como já descrito anteriormente, em seu livro "The mask of insanity". O autor foi capaz de identificar, na década de 40, 16 características diferentes que definem ou compõem o perfil clínico do psicopata. Tais características são, em suma:

a) Charme superficial e boa inteligência;

b) Ausência de delírios e outros sinais de pensamento irracional (por isso a psicopatia não deve ser considerada doença mental, mas sim um transtorno mental);

c) Ausência de nervosismo;

d) Não confiável;

e) Falsidade e falta de sinceridade

181 GLENN, Andrea.; KURZBAN, R.; \& RAINE, A. (in press). Evolutionary Theory and Psychopathy. Aggression and Violent Behavior. 
f) Ausência de remorso ou vergonha;

g) Comportamento antissocial inadequadamente motivado;

h) Julgamento deficitário e falha em aprender com a experiência;

i) Egocentrismo patológico e incapacidade de amar;

j) Deficiência geral nas reações afetivas principais;

k) Perda específica de insight;

l) Falta de resposta nas relações interpessoais gerais;

m) Comportamento fantástico e desagradável com, e às vezes sem, bebida;

n) Suicídio raramente concretizado;

o) Vida sexual e interpessoal trivial e deficitariamente integrada e

p) Fracasso em seguir um plano de vida. ${ }^{183}$

Este rol de características foi, por muito tempo, a base da Psicologia, sendo utilizado para que pudesse haver o prognóstico de psicopatia de um indivíduo. Em face destes conceitos, Robert Hare, um dos principais especialistas em psicopatia moderna, criou a "medida" de psicopatia mais amplamente usada, o denominando Psychopathy Checklist (PCL).

Baseado nas informações de Cleckley, Hare elencou 20 características que creditava aos psicopatas, e, utilizando uma pontuação para cada sintoma listado, determinou um mínimo de escore que, se atingido, configurava a psicopatia do indivíduo. Esta medida foi novamente aprimorada pelo próprio Hare, passando a ser chamada PCL-R

${ }^{182}$ GLENN, Andrea., et. al. Op. cit., p. 2.
${ }^{183}$ HUSS, MATTHEW T. Op. cit., p. 92.

A listagem de tais características também pode ser encontrada nas páginas 338-364 do livro "The Mask of insanity" já citado em referências anteriores. 
(psychopathy checklist-revised), sendo o meio mais utilizado mundialmente para diagnóstico de psicopatia. Os termos do PCL-R são:

\section{- Itens que se sobrepõem:}
a) Lábia/charme superficial - Fator 1
b) Senso grandioso de autoestima - Fator 1
c) Mentira patológica - Fator 1
d) Ausência de remorso ou culpa - Fator 1
e) Afeto superficial - Fator 1
f) Crueldade/falta de empatia - Fator 1
g) Falha em aceitar responsabilidade pelas próprias ações - Fator 1
h) Comportamento sexual promíscuo - Fator 2
i) Falta de objetivos realistas de longo prazo - Fator 2
j) Impulsividade - Fator 2
k) Irresponsabilidade - Fator 2
I) Versatilidade criminal - Fator 2

\section{- Itens que não se sobrepõem:}

m) Ludibriador/manipulador - Fator 1

n) Necessidade de estimulação - Fator 2

o) Estilo de vida parasita - Fator 2

p) Controle deficiente do comportamento - Fator 2 
q) Problemas comportamentais precoces - Fator 2

r) Muitas relações conjugais de curta duração - Fator 2

s) Revogação da liberação condicional - Fator 2

t) Delinquência juvenil - Fator $2^{184}$

Conforme é possível observar, muitas características elencadas por Hare já tinham sido observadas por Cleckley (por exemplo, charme superficial, mentira patológica, etc). O PCL-R é, então, uma lista de vinte sintomas e requer um julgamento clínico de um especialista para pontuar cada um. Cada termo é avaliado em uma escala de 3 pontos, variando de 0 a 2. Um escore de 0 indica a ausência de um sintoma, 1 indica a possível presença de um item e 2 é pontuado se o sintoma for apresentado sem dúvidas pelo examinado. Se o sujeito marca 30 pontos ou mais, já é considerado psicopata.

Além disso, Hare dividiu os elementos em dois fatores: o "Fator 1" possui oito itens, e é rotulado como o fator interpessoal/afetivos porque é composto de itens que, em grande parte, se relacionam ao comportamento interpessoal e à expressão emocional. Já o "Fator 2" é o fator do estilo de vida socialmente desviante/antissocial, com itens baseados no comportamento. ${ }^{185}$

Analisando as características elencadas por Hare, vemos como as mais importantes serem:

i) Charme superficial - o psicopata pode ser muitas vezes engenhoso e expressa-se bem. Pode ser um interlocutor ameno e divertido, com respostas rápidas e inteligentes. Contam histórias pouco prováveis, mas que chegam a convencer.

\footnotetext{
${ }^{184}$ HUSS, MATTHEW T. Op. cit., p. 94.

${ }^{185}$ HUSS, MATTHEW T. Op. cit., p. 95.
} 
ii) Personalidade egocêntrica - O psicopata tem uma visão narcisista da vida. Crê ser o centro do universo, um superior que vive suas próprias normas.

iii) Falta de remorso ou culpa - O psicopata mostra uma incrível falta de interesse pelos devastadores efeitos que suas ações têm nos demais. Não tem sentimento de culpa, não se arrependem em absoluto da dor e da destruição que causaram.

iv) Falta de empatia - Para o psicopata, os sentimentos dos outros não são de seu interesse, é incapaz de se colocar no lugar dos demais. Vê as pessoas como meros objetos que pode lhe proporcionar alguma satisfação. Mostra uma falta de empatia geral, com respeito aos sentimentos alheios e ao sofrimento de seus próprios familiares.

v) Pessoa manipuladora e mentirosa - Mentir, enganar e manipular são talentos naturais dos psicopatas.

vi) Portador de emoções superficiais e banais - O psicopata parece sofrer de uma espécie de pobreza emocional que limita a profundidade de seus sentimentos. É frio e sem emoções, mas há ocasiões em que mostram sentimentos apagados. ${ }^{186}$

Um ponto que é imprescindível observar, então, é que os psicopatas têm completo controle racional. Eles não têm delírios, psicoses nem problemas na razão. Pelo contrário, como se vê, são ótimos manipuladores, sabem se articular muito bem para obter o que querem. Não são doentes mentais e têm plena consciência do que fazem. Conforme demonstrou o professor Walter Sinnott-Armstrong, em palestra proferida na PUC-Rio ${ }^{187}$, os psicopatas são capazes de dizer o que as pessoas querem ouvir. Desta

\footnotetext{
${ }^{186}$ SÁNCHEZ GARRIDO, Francisco José. Op. cit., p. 99

${ }^{187}$ Ciclo de Palestras WALTER SINNOTT-ARMSTRONG - Are psychopaths responsible? realizada em 14.06.2011, com apoio do Grupo de Estudos ERA - Ética e realidade atual. Vídeo da palestra disponível em:
} 
forma, nem sempre o que eles falam condiz com suas ações; eles são capazes de mascarar suas atitudes.

Assim, o psicopata se apresenta clinicamente como uma contradição ambulante: por um lado, é capaz de dar respostas sociais, até moralmente apropriadas, para as situações do dia-a-dia; por sua vez, quando deixados à própria sorte, suas ações não condizem com seus relatos verbais. ${ }^{188}$

Usualmente, quando se fala em psicopata estamos nos referindo aos adultos. Entretanto, desde a infância crianças que possuem psicopatia já evidenciam alguns sintomas (como a mentira compulsiva e indiferença a regras). O próprio Hare, em seu famoso livro "Without conscience", destacou, em seu capítulo $\mathrm{X}$ (The roots of the problem), a possibilidade do diagnóstico de psicopatia em crianças que têm tendências criminosas. ${ }^{189}$

Desta forma, Hare e Paul Frick desenvolveram uma técnica similar ao PCL-R para observar se as crianças examinadas são ou não psicopatas. Esta técnica foi denominada "The Antisocial Process Screening Device" (APSD). Assim com o PCL-R, o APSD indica traços de insensibilidade e falta de emoção, em jovens de seis a 13 anos. Crianças com tendências psicopatas têm um comportamento específico e um perfil neurocognitivo similar aos dos adultos psicopatas. ${ }^{190}$

Além de tudo já exposto, é de suma importância ressaltar que nos dias atuais há uma forte linha de pesquisa neurocientífica que utiliza petscans e fMRI para analisar o cérebro de um indivíduo e concluir se o mesmo é ou não psicopata. Os estudos cerebrais para entender desvios de personalidade passaram a ter maior importância a partir do caso Phineas

<http://puc-riodigital.com.pucrio.br/cgi/cgilua.exe/sys/start.htm?tpl=view integra\&sid=142\&infoid=9726 > .

${ }^{188}$ KIEHL, Kent A. In: Without Morals: The Cognitive Neuroscience of Criminal Psychopaths. SINNOTT-ARMSTRONG, Walter. Moral Psychology - The Neuroscience of Morality: Emotion, Brain Disorders, and Development. v. 3. MIT PRESS: Cloth / January 2008.

189 Trecho do capítulo X, do livro Without conscience. Robert Hare. Disponível em: $\langle$ http://peezer.squarespace.com/storage/cau/psychopathy-and-evil/Hare_Roots.pdf $>$. Acesso em: 11 jul. 2011. 
Gage. No século XIX, em um acidente com explosivos, Gage teve sua cabeça atravessada por uma barra de ferro que penetrou em sua bochecha esquerda e saiu no topo de sua cabeça, transpassando pelo córtex prefrontal.

Depois do ocorrido, sua forma de agir moralmente foi profundamente modificada, passando a ter julgamentos morais diferentes de antes do acidente (e.g tornou-se rude, desrespeitoso, arrogante, passou a se apresentar em circos para aproveitar-se financeiramente de suas cicatrizes, etc.). Concluiu-se, a partir deste acidente, que havia uma determinada parte do cérebro que se referia exatamente à personalidade, emoções e, conseqüentemente, às escolhas morais, e que deveria ser estudada mais profundamente. Muitos sintomas de Gage são também sintomas presentes na psicopatia. ${ }^{191}$

Estudos posteriores de pacientes com danos no lobo prefrontal sugerem que o córtex orbito-frontal medeia muitos dos comportamentos relacionados à psicopatia. Danos ao córtex orbito-frontal leva a uma condição denominada "pseudopsicopatia". Essa condição se caracteriza por apresentar sintomas de irresponsabilidade, falta de insight, falta de empatia, etc.

Estudos recentes também sugerem que os danos bilaterais no córtex órbito-frontal são capazes de provocar mudanças no comportamento social. ${ }^{192}$ Entretanto, estes danos cerebrais no córtex orbito-frontal não parecem trazer toda a constelação de traços de personalidade que a psicopatia possui. Por exemplo, estes indivíduos com "pseudopsicopatia" raramente mostram agressão instrumental (que é a violência que tem um objetivo claro e definido, ou é previamente planejada), característica

\footnotetext{
${ }^{190}$ VIDING, Essi. Journal of Child Psychology and Psychiatry 45. 2004. p. 1329-1337.

${ }^{191}$ KIEHL, Kent A. Op. cit., p. 124.

192 KIEHL, Kent A. Op. cit., p. 124.
} 
importante dos psicopatas. Também não demonstram a insensibilidade exarcerbada que os psicopatas possuem. ${ }^{193}$

Em síntese, danos no córtex orbito-frontal parecem estar associado com sintomas e deficiências cognitivas que também podem ser encontrados nos psicopatas. Entretanto, apesar dessas similaridades, nenhum paciente com dano no córtex orbito-frontal foi submetido à tabela PCL-R, não sabendo quais escores marcariam.

Outro dano cerebral que levaria o paciente a ter características semelhantes à relatadas nos psicopatas seria a lesão ao "córtex cingular anterior". As lesões nesta área são raras, mas quando ocorrem, tendem a ter como resultado a apatia, falta de preocupação emocional, hostilidade, irresponsabilidade, etc. Além deste, danos ao lobo médio-temporal e na amídala estão associados há tempos com mudanças emocionais e de comportamento em macacos. ${ }^{194}$ A psicopatia é associada a dificuldades de processamento de estímulos faciais, como, por exemplo, o nojo e sinais de socorro - estes últimos creditados a ser função da amídala.

Como se pode observar, diversos danos cerebrais têm como resultados sintomas próximos ou iguais à psicopatia. Fazendo o caminho inverso, é possível analisar o cérebro de um psicopata que, a priori, não tem lesão cerebral qualquer. Isso se dá através do uso dos ERP's (event-related potentials), que são segmentos temporais de um eletroencefalograma (EEG) em andamento, e do fMRI (Functional magnetic resonance imaging). Por exemplo, evidências de neuroimagem têm mostrado que diferentes regiões do cérebro são envolvidas no processamento de palavras abstratas e palavras concretas durante tarefas de decisão léxicas.

Estudos utilizando fMRI (Functional magnetic resonance imaging) mostraram que a resposta hemodinâmica associada com o processamento de

\footnotetext{
${ }^{193}$ Ibid. p. 124

${ }^{194}$ Ibid. p. 126.
} 
palavras abstratas durante a tarefa de decisão léxica estava associado com uma maior atividade no giro temporal anterior superior direito e no córtex em torno deste, do que quando estava processando palavras concretas. Estes dados sugerem que as anormalidades comportamentais, de acordo com os ERP's observados em psicopatas, para processamento de palavras abstratas durante o contexto de tarefas de decisão lexical, podem estar relacionados com o funcionamento do lobo temporal direito anterior. Assim, os psicopatas, quando diante de palavras abstratas, têm comportamento cerebral diferente na região do giro temporal anterior superior direito do que as pessoas comuns.

Em resumo, os estudos do processamento da linguagem sugerem que a psicopatia é associada a alterações no processamento de material semântico e afetivo. Essas anormalidades parecem ser maiores quando os psicopatas estão processando estímulos abstratos e estímulos emocionais. Acredita-se que o processamento de estímulos de palavras abstratas durante as tarefas de decisão lexical dependem do chamado "giro temporal superior anterior direito". O processamento de estímulos de palavras emocionais, por sua vez, parece estar relacionado ao "cingulado anterior e posterior" e da amígdala. A literatura existente sugere, então, que durante o processamento da linguagem por psicopatas é observada atividade reduzida no giro temporal superior anterior direito, na amídala e no cingulado anterior e posterior. $^{195}$

Assim, os estudos cerebrais nos psicopatas, feitos a partir da análise cerebral destes em comparação com análise cerebrais de indivíduos que tiveram lesões em algumas áreas (e passaram a ter a denominada “pseudopsicopatia"), demonstraram que, de certa maneira, os psicopatas

\footnotetext{
${ }^{195}$ KIEHL, Kent A. Op. cit., p. 135-136.
} 
apresentam alterações de regiões cerebrais específicas que medeiam os comportamentos sociais complexos. ${ }^{196}$

Concluindo, a psicopatia pode ser, então, observada de acordo com as características já elencadas por Cleckley em 1944 e reforçadas por Hare com a criação do PCL-R. Além disso, não somente as características psicológicas transpassadas pelo indivíduo são passíveis de análise. As alterações cerebrais também são visíveis utilizando instrumentos como o $f M R I$ e o $E R P$, que são capazes de detectar as áreas reativas dos cérebros dos psicopatas quando estes são confrontados com estímulos faciais e léxicos, nos campos emocionais e afetivos, evidenciando determinadas alterações e características que os diferem da normalidade. ${ }^{197}$

\section{3 - Psicopatas e julgamentos morais}

Conforme já explicado anteriormente, os psicopatas têm sério déficit emocional, falta de afetividade e pouca ou nenhuma empatia. Estes sentimentos são essenciais para os chamados "julgamentos morais", que utilizam a razão e a emoção para decidir acerca da moralidade em determinados casos. Julgamentos morais são as decisões feitas diariamente em situações que aparecem a todo o momento, que envolvam moralidade. Isto é, baseando-se em todo um arcabouço de valores éticos prévios, um indivíduo torna-se capaz de decidir se um determinado cenário é ou não moralmente aceitável.

A questão da precedência das emoções sobre a razão quando se trata de julgamentos morais é tema bastante discutido pelos estudiosos da psicologia moral. Alguns recentes debates na literatura da psicologia social sobre moralidade têm focado exatamente neste assunto, com alguns autores

\footnotetext{
196 MOLL, Jorge; OLIVEIRA-SOUZA, Ricardo; MARROCOS, Rogerio P. In: Predadores de Corpos, predadores de almas. jan/fev/mar ed., Revista Insight - Inteligência. 2002. p. 116-122.

${ }^{197}$ Para maiores informações técnicas e detalhadas, além de outros exemplos de estudo do cérebro através do fMRI e ERP (e outras modalidades), consultar a obra de Kent Kiehl indicada em referências anteriores e a obra de Adrian Raine e Yaling Yang in: The Neuroanatomical Bases of
} 
argumentando que as emoções têm papel principal quando se fala em moralidade, enquanto outros afirmam que, quando tratamos de julgamentos morais, o papel fundamental é do raciocínio. ${ }^{198}$ De fato, este debate sobre emoções e razão acerca dos julgamentos morais remonta às mais antigas filosofias de Hume - afirmando que a razão deve ser guiada pelas emoções - e Kant - que, em resposta a Hume, ressaltava a supremacia da razão nos julgamentos morais.

Os chamados "dilemas morais" são clássicos exemplos que evidenciam o uso das emoções nos julgamentos morais. O cenário problemático tradicional apresentado pelos pesquisadores é o caso do trolley, dividido em "Switch Case" e o "Footbridge Case". Estes casos foram criados primeiramente por Phillipa Foot e depois aperfeiçoados por Judith Thomson.

A primeira situação, denominada "Switch case", expõe o seguinte problema: um bonde está passando e um indivíduo observa que em uma parte do trilho há cinco pessoas presas, enquanto nos trilhos auxiliares há uma pessoa presa. O bondinho está desgovernado, e, se seguir adiante, atropelará as cinco pessoas. O observador, porém, tem próximo a si uma alavanca, que, se acionada, mudará a direção do bonde, atingindo apenas a única pessoa que estava presa ao trilho auxiliar.

O segundo caso - "Footbridge Case" - segue a mesma lógica. Aproxima-se um bonde desgovernado, e em sua trajetória há cinco pessoas presas aos trilhos. O observador, neste caso, está acima dos trilhos, em uma ponte, junto com um indivíduo com sobrepeso. Caso este observador empurre esta pessoa próxima, ela certamente irá parar o bondinho, salvando

Psychopathy: A Review of Brain Imaging Findings em "HANDBOOK OF PSYCHOPATHY" Christopher J. Patrick, The Guilford Press, Nova York: 2006.

${ }^{198}$ PIZARRO, David.; MONIN, Benoit.; BEER, Jennifer. Deciding Versus Reacting: Conceptions of Moral Judgment and the Reason-Affect Debate. v. 11. no. 2. Review of general psychology: 2007. p. 99-111. 
as cinco pessoas (ressalte-se que o observador não tem peso suficiente para impedir a passagem do bonde, e obrigatoriamente o obeso será morto). ${ }^{199}$

A resposta mais comum para o caso é aceitar puxar a alavanca no primeiro caso, mas se recusar a empurrar outra pessoa, como no segundo caso. Juntos, esses dois dilemas criam um quebra-cabeça para os filósofos morais: O que torna moralmente aceitável sacrificar uma vida para salvar cinco no dilema "switch case", mas não no dilema "footbridge case"? Joshua Greene afirma que a resposta para esta questão é que o segundo caso envolve as emoções humanas, enquanto o primeiro não tem essa capacidade (relação de pessoalidade e impessoalidade). ${ }^{200}$ Além disso, foi descoberto que em cenários que são mais próximos e pessoais (como o "footbridge case"), partes do cérebro relacionadas ao processamento emocional são ativadas.

Greene argumentou que a aversão emocional em empurrar o homem compete com a análise racional do custo-benefício orientado para salvar mais vidas e, em casos como estes, a emoção ganha. Novamente o uso da neuroimagem torna-se presente: no caso de abaixar a alavanca, foi observada atividade no córtex pré-frontal dorsolateral (CPFDL), uma região envolvida na tomada de decisão racional e também em "controle cognitivo" de emoção, ou a capacidade de guiar a atenção e o pensamento para superar a resposta emocional prepotente. ${ }^{201}$

Assim, em uma visão geral, alguns dilemas morais têm uma participação emocional em maior medida do que outros dilemas, e essa diferença no engajamento emocional afeta os julgamentos morais dos indivíduos.

\footnotetext{
199 GREENE, Joshua. Moral Dilemmas and the "Trolley Problem" disponível em: <http://www.wjh.harvard.edu/ jgreene/>. Acesso em: 13 jul. 2011.

${ }^{200}$ GREENE, Joshua.; SOMMERVILLE, Brian.; NYSTROM, Leigh.; DARLEY, John.; COHEN, Jonathan. An fMRI Investigation of Emotional Engagement in Moral Judgment - SCIENCE. v. 293. 2001.

${ }^{201}$ GLENN, A.L.; RAINE, A.; SCHUG, R.A. The neural correlates of moral decision-making in psychopathy. Molecular Psychiatry 14. 2009, p. 5-6.
} 
A título de complementação, interessante notar que tais dilemas levam a duas correntes filosóficas importantes: a visão consequencialista e a visão deontológica. O primeiro ponto de vista verifica se uma ação é ou não moralmente correta dependendo de seus resultados. ${ }^{202}$ Já a segunda visão tem como preceito que o que se deve analisar, para verificar se é moralmente aceita ou não, é a própria ação em si, e não os resultados. É o modo de agir e lidar individual ${ }^{203}$.

Assim, no caso acima exposto, normalmente quem responde que puxaria a alavanca para salvar cinco pessoas e matar uma, está agindo sob visão consequencialista (já que acreditam que é possível eliminar uma vida a fim de salvar várias). Por sua vez, quem não empurra o gordinho de cima da ponte, para parar o bondinho, age conforme os preceitos deontológicos (pois entendem, racionalmente pensando, que matar alguém é, per si, uma ação moralmente errada).

Neurologicamente analisando, foi realizado um estudo com pacientes que têm deterioração emocional por lesão ao Córtex Ventromedial Préfrontal (VMPC). Os pacientes têm como características principais a falta de empatia e o afeto reduzido. Neste caso, Liane Young e colegas fizeram testes em um grupo de seis pacientes, com lesões bilaterais de VMPC, a fim de determinar se o processamento sentimental observado nestes casos é ou não necessário para influir nos julgamentos morais. A estes indivíduos, foi mostrada uma série de situações morais pessoais e impessoais, solicitando que valorassem e decidissem como agir.

O resultado foi de que estes pacientes respondem da mesma forma que a média das pessoas sem lesão alguma às questões impessoais, porém no que tange às questões pessoais eles tendem a escolher uma atitude sentimentalmente prejudicial, se isso gerasse um benefício a um maior

\footnotetext{
202 SINNOT-ARMSTRONG, Walter. Consequentialism. mai. 2003. Disponível em:
} $<$ http://plato.stanford.edu/entries/consequentialism/>. Acesso em 19 jul. 2011. 
número de pessoas (tendem a ser consequencialistas em qualquer cenário apresentado, independente da ação) ${ }^{204}$.

Desta forma, apesar de existir vasta discussão argumentando se as emoções são ou não mais importantes que a razão quando feito um julgamento moral, não há como negar que o emocional exerce sim papel importante nestas decisões. Sentimentos como culpa ou vergonha são necessários, por exemplo, para prevenir um indivíduo de cometer determinadas ações por julgá-las moralmente incorretas. ${ }^{205}$ As emoções tornam-se fundamentais para guiar as decisões morais e as ações individuais.

Nesse sentido, duas linhas filosóficas surgem como resposta à questão das decisões morais. Uma ação moralmente "boa" requer tanto um julgamento moral sincero, quanto uma motivação moral. Para os chamados “internalistas", estes dois requisitos estão internamente ligados (seja por sentimentos, seja pela razão). Já para os "externalistas", a conexão entre julgamentos morais e as ações é lapidada por motivações externas ao próprio julgamento. Para estes, os julgamentos morais são apenas crenças, por isso não podem motivar uma ação. ${ }^{206}$

A motivação para fazer algo que a moralidade demanda é baseada principalmente nas emoções. Esta motivação depende dos julgamentos morais, que é um julgamento de que algo tem significado moral (para expressar julgamentos morais utilizam-se termos tais como "certo" e "errado", "bom" e "mau”, "justo" e "injusto" etc). Normalmente, quando uma pessoa julga que algo tem significação moral, costuma a agir de acordo

\footnotetext{
203 ALEXANDER, Larry.; MOORE, Michael. Deontological ethics - nov. 2007. Disponível em: <http://plato.stanford.edu/entries/ethics-deontological/>. Acesso em 19 jul. 2011.

204 CUSHMAN, F.; GREENE, J.; YOUNG, L. The Multi-system Psychology. The Moral Psychology Handbook: Oxford University Press, USA. 2010. p. 53-54.

${ }^{205}$ HUEBNER, Bryce.; DWYER, Susan.; HAUSER, Marc. The role of emotion in moral psychology. Trends in Cognitive Sciences. v. xxx. no. (in press).

${ }^{206}$ KENNETT, Jeanette.; FINE, Cordelia. In: Internalism and the Evidence from Psychopaths and
} 
com esse entendimento. ${ }^{207}$ Assim, sabendo que uma ação é "ruim" (seja pelos seus resultados, seja pelo agir em si), um sujeito comum não a cometerá, pois não será motivado a tal, visto entendê-la como moralmente incorreta. O papel das emoções, então, é de fornecer o arcabouço a cada pessoa, para que ela seja capaz de julgar uma situação como moralmente aceitável - utilizando a empatia, compaixão, afeto, respeito, etc. - e sintase, sinceramente, impelida a realizá-la ou não.

Se as decisões morais são baseadas em emoções, é de se questionar, então, se os psicopatas - que têm por característica principal a falta delas são capazes ou não de fazer julgamentos morais e guiar-se conforme este entendimento. Nas palavras do professor Sinnot-Armstrong, há duas possibilidades óbvias. Em uma visão clássica, os psicopatas fazem julgamentos morais, mas simplesmente não ligam se seus atos são moralmente corretos. Falta-lhes a motivação acima explicada. Já numa visão não-clássica, os psicopatas não fazem realmente julgamentos morais, eles apenas fingem fazê-los a fim de manipular as aparências e as pessoas ao redor. ${ }^{208}$

O ponto de vista clássico mencionado pelo professor SinnottArmstrong afirma que os psicopatas realmente fazem julgamentos morais, mas não conduzem suas ações de acordo com tais entendimentos. Nesse sentido, a corrente que adota esta posição preceitua que as experiências emocionais na verdade sucedem os julgamentos morais, e não os antecede nem os guiam, não sendo pré-requisito necessário. Assim, os psicopatas são capazes de realizar os julgamentos morais tanto quanto uma pessoa comum da população.

\footnotetext{
"Acquired Sociopaths" - SINNOTT-ARMSTRONG, Walter - Moral Psychology - The Neuroscience of Morality: Emotion, Brain Disorders, and Development. v. 3, MIT PRESS: Cloth / January 2008. p. 173.

${ }^{207}$ PRINZ, Jesse.; NICHOLS, Shaun. Moral emotions. Oxford University Press: The Moral Psychology Handbook, USA. 2010. p. 113.

${ }^{208}$ SINNOT-ARMSTRONG, Walter. Op. cit.,
} 
O desvio do psicopata é que ele simplesmente não liga para o que entende como moralmente reprovável/permissivo e por não se ocupar com outros tipos de sistema motivacional que inspiram o comportamento moralmente adequado e inibem aquele inadequado. ${ }^{209}$ Assim, eles são plenamente capazes de fazer e acreditar nos julgamentos morais, mas lhes falta o mecanismo que traduz esta habilidade cognitiva em emoções normais ou motivações, a fim de evitar ações imorais. ${ }^{210}$

Por sua vez, como já citado anteriormente, uma visão não-clássica afirma que os psicopatas não são capazes de fazer julgamentos morais. Essa teoria é consequência de uma lógica bastante razoável, mas que pode ter falhas se não analisada corretamente. A premissa, demonstrada pelos sentimentalistas adeptos da teoria internalista, é que os julgamentos morais são baseados nas emoções; os psicopatas são carentes emocionalmente; logo, os psicopatas não são capazes de fazer julgamentos morais. ${ }^{211}$

Entretanto, é preciso analisar com mais cuidado a capacidade ou não dos psicopatas em fazer julgamentos morais. Considerando que as emoções têm papel fundamental nas decisões morais, faz sentido afirmar que a falta delas implica diretamente na impossibilidade de realizar tais julgamentos.

Os internalistas afirmam que os psicopatas não fazem julgamentos morais "genuínos" ${ }^{, 212}$ Isso quer dizer que eles não compreendem o sentido das palavras como as pessoas comuns entendem. Por exemplo, um psicopata pode dizer que sabe o que é beleza, feiúra, bem, mal, amor, horror, mas na verdade ele não tem como saber, pois não há nada em sua órbita de consciência para que ele possa comparar. Ele pode repetir as

\footnotetext{
${ }^{209}$ CIMA, Maaike.; TONNAER, Franca.; HAUSER, Marc D. Psychopaths know right from wrong but don't care - Social Cognitive \& Affective Neuroscience. v. 5. Issue 1, p. 59-67.

${ }^{210}$ SINNOT-ARMSTRONG, Walter.; BORG, Jana Schaich. Psychopaths and Moral Judgments. - trabalho acadêmico ainda em andamento.

${ }^{211}$ MONTELLO, Maria. Rational Requirements for Moral Motivation: The Psychopath's Open Question. 2011. Philosophy Theses. Paper 93. Disponível em:

$<$ http://digitalarchive.gsu.edu/cgi/viewcontent.cgi?article=1094\&context=philosophy theses $>$

p. 14. Acesso em 20 jul. 2011.

${ }^{212}$ Ibid. p. 21.
} 
palavras e dizer levianamente que ele entende, mas, ainda assim, não há nenhuma maneira para ele perceber que ele não entende. Dessa maneira, eles são capazes de falar o que o seu interlocutor quer ouvir, pois que sabem perfeitamente manipular as feições e a fala a fim de atingir seus objetivos.

Adultos psicopatas e crianças com tendências psicopatas são insensíveis às diferenças entre as ações consideradas erradas convencionalmente (como, por exemplo, ir de pijama a um restaurante) e as erradas moralmente (matar o garçom do restaurante, por exemplo). Essa distinção é uma das bases principais para um raciocínio moral e, consequentemente, um posterior julgamento moral ${ }^{213}$. Portanto, nesta segunda visão, os julgamentos morais dos psicopatas não são realmente morais, uma vez que não são diferentes de julgamentos com base em convenções sociais. $^{214}$

A importância em saber se os psicopatas fazem ou não julgamentos morais é a relevância da consciência do indivíduo em seu entendimento acerca de fatos criminosos e de determinar-se de acordo com tal entendimento. Saber se sua ação é genuinamente motivada, tendo plena consciência da ilicitude e podendo evitar de fazê-lo, ou se sequer sabe compreender a antijuridicidade da ação, ou, ainda, a impossibilidade psicológica de determinar-se de acordo com seu entendimento, caso saiba da ilicitude da ação, é importante para começar a se discutir acerca da responsabilidade penal dos psicopatas.

\footnotetext{
${ }^{213}$ KENNETT, Jeanette.; FINE, Cordelia. Op. cit., p. 175.

${ }^{214}$ MONTELLO, Maria. Op. cit., p. 23.
} 


\section{CAPÍTULO 3 - A RESPONSABILIDADE PENAL DOS PSICOPATAS}

Para que possamos adentrar no tema principal da pesquisa, se faz necessário recobrar alguns conceitos-chave expostos nos capítulos anteriores.

Conforme já pudemos demonstrar quando abordamos a culpabilidade, o Direito Penal foi criado com a finalidade de proteger os bens mais importantes e necessários para a própria sobrevivência da sociedade, essenciais ao indivíduo e à comunidade. ${ }^{215}$ Bens jurídicos como a vida, propriedade, incolumidade física e psíquica, são penalmente tutelados pelo Direito Penal como última ratio - ou seja, a maioria dos bens previstos também já é protegida por outras áreas do Direito. Assim, o Direito Penal é o setor do ordenamento jurídico que define o que são crimes, comina as penas e prevê medidas de segurança aplicáveis aos autores das condutas incriminadas. ${ }^{216}$

Os fatos sociais da vida comum são, em sua maioria, irrelevantes penais. Entretanto, quando estes fatos sociais lesionam (ou ameaçam lesionar) alguns destes bens supracitados, passam a ser puníveis. São denominados, então, fatos típicos. Estes fatos estão previstos nas leis penais. Logo, aquele que age conforme o núcleo de algum dispositivo penal incriminador, cumprindo todas as elementares do tipo, estará cometendo um crime.

O conceito analítico de crime, aquele que adotamos nesta pesquisa, é entendido como a conduta típica, antijurídica e culpável. Típica exatamente por existir disposição legal prevendo que determinada conduta é vedada. Antijurídico é o fato ilícito, ou seja, contrário ao ordenamento jurídico. Por

\footnotetext{
${ }^{215}$ GRECO, Rogerio. Op. cit., p. 4.
} 
fim, culpável é o elemento subjetivo, caracterizado como imputabilidade, consciência efetiva da antijuridicidade e exigibilidade de conduta conforme ao Direito. Dessa forma, quando o indivíduo pratica uma ação típica, antijurídica e culpável, diz-se que cometeu um crime.

Para que o agente possa ser responsabilizado penalmente pelo fato típico e ilícito que cometeu, é preciso que seja imputável. A imputabilidade é, então, "a possibilidade de se atribuir, imputar o fato típico e ilícito ao agente. A imputabilidade é a regra e a inimputabilidade é a exceção". ${ }^{217}$

O artigo 26 do Código Penal Brasileiro previu, como já estudamos, a hipótese clássica de inimputabilidade, afirmando que "é isento de pena o agente que, por doença mental ou desenvolvimento mental incompleto ou retardado, era, ao tempo da ação ou da omissão, inteiramente incapaz de entender o caráter ilícito do fato ou de determinar-se de acordo com esse entendimento.". A redação do caput do referido dispositivo leva à conclusão que o legislador adotou, neste caso, o critério biopsicológico para a aferição da inimputabilidade do agente.

Diante do exposto, eis que surge um questionamento essencial, em decorrência de todo o estudo previamente demonstrado: o que ocorre com os psicopatas que cometem crimes? Eles podem ser considerados plenamente imputáveis ou não?

Como já explicado anteriormente, nem todos os psicopatas são criminosos, conforme dizia Cleckley em 1941. Robert Hare, em seu livro "Cobras de terno: os psicopatas de sucesso" afirma a existência de psicopatas em todos os locais possíveis (vizinhos, amigos, colegas de trabalho, etc.), principalmente no mundo dos negócios ${ }^{218}$, lugares em que certamente podem causar perturbações. Quanto a estes sujeitos, que não

\footnotetext{
${ }^{216}$ SANTOS, Juarez Cirino dos. Direito Penal: Parte Geral. $3^{\mathrm{a}}$ ed. Curitiba: Lumen Juris, 2008. p. 3.

${ }^{218}$ HUSS, MATTHEW T. Op. cit., p. 98.
} 
cometem crimes, mas que acabam prejudicando outros de outras formas, o Direito tem pouca resposta.

Algumas medidas judiciais, como a Ação Cautelar, poderiam ser utilizadas a fim de prevenir a presença próxima de alguns psicopatas (aplicadas também a qualquer indivíduo, em geral). Por exemplo, no caso de um marido psicopata que arruína a vida da família, a esposa poderia ajuizar uma medida cautelar de separação de corpos de caráter urgente, para posterior separação judicial; ou então, um filho psicopata que destrói o lar, é possível que os pais possam ajuizar uma ação cautelar com pedido de afastamento do lar. ${ }^{219}$

Porém, no que tange aos psicopatas criminosos, há ainda muito que se estudar.

Conforme já explicado, a psicopatia não é entendida como doença mental. Assim, em uma primeira análise, a inimputabilidade prevista no artigo 26 do Código Penal não poderia ser aplicada, devendo o psicopata criminoso ser condenado caso provado ter cometido o fato típico.

Entretanto, é completamente duvidosa a aplicação do parágrafo único do referido artigo, que dispõe sobre os semi-imputáveis, uma vez que a psicopatia talvez possa se encaixar como perturbação da saúde mental e, por isso, dificulta saber se aquele criminoso tem a relativa capacidade de entender o caráter ilícito do fato e de agir conforme este entendimento.

A doutrina e jurisprudência brasileira pouco se manifestaram sobre a imputabilidade dos Psicopatas. Os poucos artigos publicados acerca do tema ou utilizam o termo "psicopata" indevidamente, caracterizando aquele estereótipo de serial killer que tentamos refutar; ou o mesmo termo é

\footnotetext{
${ }^{219}$ CAMARA, Alexandre. Lições de direito processual civil. v. III. 16 ${ }^{\mathrm{a}}$ ed. Rio de Janeiro: Lumen Juris, 2010. p. 10. e artigo 806 do Código de Processo Civil.

$\mathrm{O}$ processo cautelar tem por fim garantir a efetividade de outro processo, ao qual o mesmo se liga necessariamente. A tutela jurisdicional cautelar se limita a proteger a execução contra os males do
} 
aplicado aos indivíduos que possuem demências mentais, como era entendido nas décadas de 30 a $50 .^{220}$

Já no exterior, muitos são os estudos realizados em face destes indivíduos. A base principal da nossa pesquisa foram as publicações de diversos autores estrangeiros, em sua maioria argentinos e espanhóis, que se atentaram para procurar uma resposta quanto à imputabilidade dos psicopatas.

Um dos primeiros casos em que se cogitou a aplicação ou não da inimputabilidade no caso de crimes cometidos por psicopatas foi no "Caso Castruccio", em 1888, Buenos Aires, Argentina.

Com vinte e cinco anos, baixa estatura e largos braços, uma grande cabeça redonda coberta de cabelos ruivos e com orelhas enormes, Luis Castruccio era um imigrante que em 1878 chegou ao país para se dedicar a tarefas serviçais e buscar algum sucesso profissional. ${ }^{221}$

Após fracassar em diversos empregos na província de Buenos Aires, decidiu aplicar um golpe: contrataria uma apólice de seguro de vida em nome de alguém para, em caso de falecimento desta pessoa segurada, receber o dinheiro devido como beneficiário único. Acabou por conhecer

tempo, protegendo um bem que será, obrigatoriamente, discutido em uma ação própria a ser ajuizada no prazo de 30 dias.

${ }^{220}$ Por exemplo, é possível observar diversas leis, decretos e decretos-leis criados com base na proteção dos "psicopatas". Nestes casos, não se trata dos mesmos indivíduos que estudamos aqui, mas sim daqueles acometidos por doenças mentais. Ex: Dec. 24.559/1934 - "DISPOE SOBRE A PROFILAXIA MENTAL, A ASSISTÊNCIA E PROTEÇÃO A PESSOA E AOS BENS DOS PSICOPATAS, A FISCALIZAÇÃO DOS SERVIÇOS PSIQUIÁTRICOS E DÁ OUTRAS PROVIDÊNCIAS"; Lei 325/1936 - "AUTORIZA O PODER EXECUTIVO A DESPENDER 5.000:000\$000 NA CONSTRUCAO E INSTALACAO DE LEPROSARIOS E 2.000:000\$000 NA CONSTRUCAO DE OBRAS DESTINADAS A ASSISTENCIA A PSICOPATAS", Decreto-Lei 7055/1944 - “CRIA O CENTRO PSIQUIÁTRICO NACIONAL E EXTINGUE O CONSELHO DE PROTEÇÃO AOS PSICOPATAS E A COMISSÃO INSPETORA, NO MINISTÉRIO DA EDUCAÇÃO E SAÚDE, E DÁ OUTRAS PROVIDÊNCIAS.” e Decreto 46522/1959 - “ABRE AO MINISTERIO DA SAUDE O CREDITO ESPECIAL DE CR 10.000.000,00, PARA OCORRER AO PAGAMENTO DE EQUIPAMENTO FORNECIDO AO HOSPITAL DE PSICOPATAS NO RIO GRANDE DO NORTE."

${ }^{221}$ ZARLENGA, Marcelo. El psicopata perverso em la jurisprudência argentina: uma primera aproximación. v. 6. 10 a ed. Buenos Aires: Cuadernos de doctrina y Jurisprudencia Penal. p. 481. 
Alberto Bouchot Constantin, conseguindo que este assinasse o contrato obviamente sem saber as reais razões de Castruccio. ${ }^{222}$

Foram diversas as tentativas de matar Constantin, todas infrutíferas em razão do meio utilizado: clorofórmio. Em decorrência do insucesso de sua empreitada, passou a estudar em livros de Química outras substâncias capazes de assassinar um ser humano. Acabou escolhendo arsênico. Anotava cada vez que colocava o veneno nos alimentos de Constantin, além de tomar nota das visitas do médico que, a seu pedido, ia visitar o "amigo" e acabou diagnosticando grave crise de gastrite. ${ }^{223}$

Poucos dias após o início das doses de veneno, encontrando-se Constantin agonizante e padecendo, Castruccio decidiu asfixiá-lo, colocando seus dedos em seu nariz e boca. Logo em seguida, deitou-se em uma cama próxima e dormiu tranquilamente, sem sequer sentir remorso do que fez com seu colega. ${ }^{224}$

Tal como planejava, o médico atestou o óbito de Constantin e o enterro ocorreu sem novidades. No entanto, a precipitação de Castruccio e sua vaidade foram decisivas para cair por terra seus sonhos de fortuna. Em primeiro lugar, se apressou em informar à Companhia de Seguros sobre a morte do segurado, o que gerou suspeitas que culminaram com uma denúncia policial e a detenção preventiva do beneficiário da apólice.

Posteriormente, chegando ao ponto de até fazer carinhos na mão de Constantin durante a autópsia, após ser inquirido constantemente pelo Dr. Agustin Dragó, Castruccio acabou revelando a autoria do crime, afirmando que "o matou como Otello a Desdémona".

\footnotetext{
${ }^{222}$ Ibid. p. 482.

${ }^{223}$ Ibid. p. 482.

${ }^{224}$ Ibid. p. 482.
} 
Somente lamentava a perda de dinheiro de toda a farsa, incluindo os gastos com a apólice, com o médico e com o enterro, além da rapidez com que foi descoberto: apenas oito dias. ${ }^{225}$

O julgamento de Castruccio foi marcado pela presença de defensores que afirmavam sua irresponsabilidade penal, pois seria um louco moral; por outro lado, peritos forenses que, utilizando os ensinamentos de Lombroso, o classificaram como delinquente nato. Foi condenado à pena de morte, afastando qualquer atenuante e aplicando as agravantes de premeditação, meio cruel (veneno) e perfídia.

Não obstante, a caminho do cadafalso, chegou um comunicado de mudança da pena, permanecendo Castruccio alojado na Penitenciária Nacional por muito tempo, até ser movido ao Hospício de las Mercedes. ${ }^{226}$

Em uma breve análise legal dos elementos históricos desse caso, podemos observar que foi aplicado de plano o art. 54, inciso I e 95, inciso I, do Código Penal vigente à época, que determinava a pena de morte nos casos de homicídio causado por perfídia ou por meio de veneno. O julgador afastou a possibilidade de aplicar a Castruccio qualquer isenção de culpabilidade previstas no art. 81, inciso I, que determinava a inimputabilidade nos casos de loucura, imbecilidade absoluta ou perturbação dos sentidos da inteligência. ${ }^{227}$

Mesmo tendo sido levantada a hipótese de "loucura moral", termo utilizado historicamente (e mais bem detalhado no capítulo anterior), o juiz afastou a incidência, considerando Castruccio imputável (tendo sido, somente após, transferido para um Hospício). De qualquer forma, não se olvida que tal caso é um marco legal para estudo da psicopatia diante dos tribunais, à época das primeiras pesquisas psiquiátricas.

\footnotetext{
${ }^{225}$ Ibid. p. 483.

${ }^{226}$ Ibid. p. 483-484.

${ }^{227}$ Ibid. p. 484.
} 
Nos dias de hoje, com pesquisas mais avançadas nos campos da psicologia e do direito, importante destacar as diversas visões acerca da imputabilidade ou não dos psicopatas.

Em decorrência dos diversos posicionamentos acerca da psicopatia, se torna indubitável que a mesma cause dissonância em suas consequências jurídico-penais. Se nem os especialistas em psiquiatria/psicologia forense conseguem determinar com completa certeza quem são os psicopatas, torna-se difícil saber se um sujeito pode ser considerado inimputável ou não.

O entendimento sumário pela doutrina é o de que a psicopatia, por si só, não leva à inimputabilidade do agente ${ }^{228}$.(lembrando que a exclusão de culpabilidade é exceção, e não regra). Aqueles que adotam a posição da inimputabilidade (ou semi-imputabilidade) afirmam que estes indivíduos são incapazes de compreender a antijuridicidade de uma ação e de se orientar sob tal entendimento.

Mirabete, por exemplo, afirma que:

Os psicopatas, as personalidades psicopáticas, os portadores de neuroses profundas, etc. em geral têm capacidade de entendimento e determinação, embora não plena. Estão na mesma categoria legal os que possuem o desenvolvimento mental incompleto, mas que atingiram certo grau de capacidade psíquica de entendimento e autodeterminação de acordo com as regras sociais [silvícolas em acultuação, surdos-mudos em processo de instrução] etc. Por fim, incluem-se os agentes com desenvolvimento mental retardado, que nas faixas mais elevadas têm alguma capacidade de entendimento e autodeterminação. Em todas as hipóteses, comprovadas por exame pericial, o agente será condenado, mas, tendo em vista a menor reprovabilidade de sua conduta, terá sua pena reduzida entre um e dois terços, conforme o art.26, parágrafo único [...]. 229

Zaffaroni, em voto proferido em sessão de julgamento na Suprema

Corte Argentina, se posicionou da seguinte maneira:

la principal caracteristica de la psicopatia 'es su conducta antisocial, es decir, que su actitud básica es agresivamente antisocial' (...) Esta característica se pone

\footnotetext{
${ }^{228}$ COVELLI, Luciano A. La Psicopatia en la condena y en la ejecución de la pena privativa de libertad. n. 1. Buenos Aires: Revista de Derecho Penal, 2009. p. 318.

${ }^{229}$ MIRABETE, Julio Fabrini. Código Penal Interpretado. São Paulo: Atlas, 1999. p. 224.
} 
claramente de manifiesto en la conducta de S.V, que relata al ser preguntado por sus antecedentes y que registra en la larga lista de certificaciones de autos que culminan a fs. 434/5. No se trata únicamente de lo que la crónica policial llama 'frondoso prontuario', sino de algo que llama mucho más la atención. Hay aqui un proceder que no parece responder a una lógica más o menos razonable, ni siquiera desde el ángulo de una ética delincuencial. S. V. Es continuamente descubierto y procesado, y confiesa incluso no se hubiese sabido nunca o no se hubiese podido probar. Parece que, en general, no le asigna mucha importancia a las consequencias penales de su conducta (...) Conforme al actual concepto de enefermidad mental, a los aportes de las ciencias e de la conducta, que permiten conocer hoy mucho mejor las caracteristicas y limitadas capacidades de los psiópata 0 , particularmente, frente a un concepto normativo de la culpabilidad penal, el psicópata nunca puede ser considerado imputable ${ }^{230}$

Neste caso exposto, Zaffaroni e a corte argentina entendem que S.V é inimputável e, por isso, a ele deve ser aplicada medida de segurança, com internação em local apropriado para que haja sua recuperação e tratamento. Entretanto, afirma ainda o excelentíssimo ministro:

Dezconozco la existencia de un estabelecimiento adecuado donde S.V pueda ser objeto de um tratamineto que tende a mejoralo. De cualquier manera, la inexistencia de un estabelecimiento en estas condiciones es un problema de la administracion penitenciaria, que debía haberlos creado en 1921 y en modo alguno puedo tomar esa falla del poder público en perjuicio del procesado y del interés social, pues carecería de todo sentido que un defecto del poder público motivase una condena cuando se impone una absolución y diese lugar a un riesgo social y al mismo tiempo una injusticia. Consiguientemente estimo que el procesado debe ser internado en el estabelecimiento que la Dirección del Servicio Penitenciario Federal considera adecuado para su eventual recuperación y permanecer allí hasta que se compruebe la desaparición de las condiciones que lo hacen peligroso. ${ }^{231}$

Por sua vez, a imputabilidade parece ser a saída mais factível aos psicopatas. Francisco José Sanchez Garrido, por exemplo, afirma que os psicopatas compreendem a ilicitude de seus atos, e, por conseguinte, atuam conforme tal conhecimento. A capacidade intelectual e volitiva destes sujeitos está intacta. ${ }^{232}$

Desta forma, seria impossível aplicar ao psicopata a isenção de responsabilidade penal, uma vez que esta requer a incompreensão da ilicitude da ação e a impossibilidade de agir conforme tal entendimento.

\footnotetext{
${ }^{230}$ COVELLI, Luciano. Op. cit.,. p. 321.

${ }^{231}$ ZARLENGA, Marcelo. Op. cit., p. 518.

${ }^{232}$ GARRIDO, Francisco - op. Cit., pag. 117
} 
Garrido, professor de Direito Penal e Criminologia na UNED Espanha, afirma ainda que, naquele país, não havia dúvidas, antigamente, de que um psicopata era imputável. Isso porque o Código Penal antigo previa que a excludente de imputabilidade somente se dava em casos de enfermidade mental, e a psicopatia não entrava nessa hipótese, eis que não considerada como tal. ${ }^{233}$

O problema, diz o autor em referência, foi quando o legislador introduziu a possibilidade de aplicação da isenção de culpabilidade nos casos em que qualquer anomalia ou alteração psíquica poderia interferir na cognição da ilicitude e compreensão dos fatos, resultando na inimputabilidade do psicopata. ${ }^{234}$ Traçando um paralelo, seria uma situação parecida com a semi-imputabilidade trazida no nosso Código Penal.

O Tribunal Supremo da Espanha já se manifestou, em 2001, que a psicopatia não é verdadeiramente uma enfermidade mental, mas sim anomalias estruturais da personalidade. ${ }^{235}$ Desta forma, este tribunal passou a entender que os psicopatas são plenamente imputáveis, como regra geral. Exceções são possíveis, por exemplo, se a psicopatia está acometida de outros fatores de caráter endógeno, como o uso de drogas e álcool, que influenciem diretamente na capacidade volitiva do psicopata. ${ }^{236}$

Em outros ordenamentos jurídicos a resposta do Direito Penal diante dos psicopatas pode ser diferente. A inimputabilidade dos mesmos é flagrante, por exemplo, no Código Penal Alemão, em seu art. 20, que prevê a isenção de culpabilidade nos casos em que, ao tempo do crime, o sujeito tinha transtorno psíquico patológico, ou profundo transtorno de consciência, debilidade mental ou outra anomalia mental grave, tornando-o incapaz de compreender a antijuridicidade do fato típico cometido. ${ }^{237}$

\footnotetext{
${ }^{233}$ Ibid. p. 118.

${ }^{234}$ Ibid. p. 118.

${ }^{235}$ Ibid. p. 118.

${ }^{236}$ Ibid. p. 118-119.

${ }^{237}$ Ibid. p. 120.
} 
A lei alemã elenca a psicopatia como "outra anomalia mental grave". Isto é, somente poderá ser inimputável aquele psicopata que tenha traços evidentes de enfermidade. Deve ser grave, com constantes recaídas ao cometimento de crimes e com a completa ineficácia de sanções penais. Estas são características comuns aos psicopatas, que tendem a ser criminosos reincidentes e aos quais fracassam qualquer meio terapêutico ou reabilitador de inserção do mesmo na sociedade. ${ }^{238}$

O Código Penal Italiano estabelece, nos artigos 88 e 89, como excludente de imputabilidade o vicio total da mente no momento do crime, afastando a capacidade de entender ou de querer, por conta de enfermidades. Já o artigo 89 prevê o vício parcial da mente quando a enfermidade atua de certa forma que não exclui a capacidade de entender ou de querer. ${ }^{239}$

Diz Garrido que a doutrina italiana (autores como Fiore e Bertolino) não abarca o conceito de psicopata como aplicável à enfermidade mental, salvo aqueles que representassem uma maior severidade, em cujo caso poderia justificar o vício parcial da mente. ${ }^{240}$ Ou seja, novamente aqui vemos a regra da imputabilidade dos psicopatas, salvo raras exceções no caso concreto.

Por fim, no Código Penal Francês, a exigência é do pressuposto biológico-psicológico, previsto no art. 121-1. Assim, é inimputável aquele que em decorrência de transtorno psíquico ou neuropsíquico não é capaz de compreender a antijuridicidade do fato e nem de agir conforme tal entendimento. Interessante notar que, assim como no Brasil, o CP Francês prevê a possibilidade de semi-imputabilidade nos casos em que a

\footnotetext{
${ }^{238}$ Ibid. p. 120.

${ }^{239}$ Ibid. p. 122.

${ }^{240}$ Ibid. p. 122.
} 
culpabilidade é diminuída e que o sujeito não tivesse uma enfermidade "grave". 241

Assim, adota também a imputabilidade do psicopata como regra exceto nos casos em que esse transtorno se mostrar severo ou grave.

Faz-se necessário, ainda, retornar ao debate acerca dos julgamentos morais, conforme já comentamos no último capítulo.

A habilidade de responder às razões morais, em particular, é necessária para a responsabilidade criminal, uma vez que um dos objetivos principais do Direito Penal é condenar o que é moralmente errado e que atinge bens preciosos para a vida em sociedade. Assim, aqueles sujeitos que adotam a denominada teoria clássica (conforme vimos no capítulo sobre os psicopatas), afirmando serem os psicopatas plenamente capazes de realizar julgamentos morais e direcionar suas ações de acordo com esse entendimento, acreditam serem os mesmos imputáveis, sequer cogitando a redução de pena por semi-imputabilidade. Isso porque entendem que os psicopatas agem intencionalmente e voluntariamente ${ }^{242}$.

Para estes, os psicopatas sabem a diferença entre o certo e o errado, mas emocionalmente não têm a sensação do que é certo e errado. Ao contrário de indivíduos com transtornos mentais, como a esquizofrenia ou demência, que podem ter a capacidade de cognição prejudicada, os psicopatas entendem que estas ações criminosas específicas são contra a lei. $^{243}$.

\footnotetext{
${ }^{241}$ Ibid. p. 123.

O autor ainda critica esse critério de gravidade, já que é difícil mensurar o grau de gravidade de um psicopata - algumas características se destacam mais, outras menos, etc.

${ }^{242}$ SINNOT-ARMSTRONG, Walter. Op. cit.

${ }^{243}$ GLENN, Andrea.; RAINE, A.; LAUFER, W.S. Is it wrong to criminalize and punish psychopaths? Emotion Review. 3. 2011. p. 302-304.
} 
Por outro lado, adotando a posição não-clássica, a qual afirma que os psicopatas não são capazes de fazer julgamentos morais reais, que apenas dizem o que o interlocutor almeja escutar sem estar genuinamente motivado por aquilo que fala, seria possível a aplicação da semi-imputabilidade.

Quando um psicopata afirma que é errado machucar as pessoas, eles não estariam expressando o mesmo significado que as pessoas comuns expressam com esta mesma sentença, já que os psicopatas não estão devidamente motivados no que dizem e suas palavras passam a ter outros significados. Ao invés disso, os psicopatas usam suas palavras em um sentido invertido ("inverted-commas sense") ${ }^{244}$, isto é, eles sabem as palavras, mas não seu real significado.

Nesse sentido, não sendo capazes de se motivar de acordo com o que dizem, impossibilitados de realizar julgamentos morais, seria possível a aplicação da semi-imputabilidade, já que passam a ser incapazes de agir conforme esse falso entendimento. Ou seja, eles dizem que matar é errado, mas mesmo assim matam, pois eles não têm plena consciência do sentido que é "matar" para as pessoas comuns, exatamente pela falta de emoções inerente à psicopatia, sendo estas necessárias para o comportamento individual.

Assim, estaríamos diante de uma incompreensão real da antijuridicidade da ação e da incapacidade de agir conforme tal entendimento.

Infelizmente toda essa discussão acerca da imputabilidade do psicopata, apesar de sua relevante importância ${ }^{245}$, não passa do escasso campo acadêmico no Brasil.

\footnotetext{
${ }^{244}$ NICHOLS, Shaun. How Psychopaths Threaten Moral Rationalism, or Is it Irrational to Be Amoral? The Monist. 85. 2002. p. 285-304.

${ }^{245}$ De acordo com o professor Sinnott-Armstrong, saber se um criminoso é psicopata, é de extrema importância. Os psicopatas têm um custo muito alto para a sociedade (custos, e.g, com o encarceramento nos EUA é de U\$250 bilhões por ano). Por exemplo, de $15 \%$ a $20 \%$ dos prisioneiros do sexo masculino, de prisões de segurança média, são psicopatas; $37 \%$ dos
} 
O Judiciário Brasileiro ainda não está preparado para utilizar as técnicas da Psicologia Forense e as experiências neurocientíficas já listadas no capítulo anterior, a fim de diagnosticar o criminoso psicopata. Em primeiro lugar, é cediço que não há verbas para contratar peritos qualificados, que sejam capazes de utilizar a tabela PCL-R ou qualquer outra similar, a fim de verificar a psicopatia no criminoso em questão. $\mathrm{O}$ papel do perito judicial, na área criminal, acabou por ser limitado apenas na diagnose de doença mental, a fim da aplicação ou não do artigo 26 do Código Penal.

Além disso, ultrapassando o fato de o Judiciário estar abarrotado de processos, sendo quase impossível dar a atenção necessária para cada um, não há que se falar na compra de máquinas de ressonância, em sua maioria importadas, para análise cerebral do sujeito (pela técnica já mencionada de fMRI, por exemplo). O alto valor destas, a incapacitação de funcionários para manejá-la e a falta de tempo e espaço para que tais exames sejam realizados, impedem o prognóstico eficaz de um psicopata.

Ainda assim, mesmo que houvesse possibilidade de fazer tais exames, verificando a psicopatia in casu, a relevância prática de tal diagnóstico é quase nula. Conforme debatemos, a semi-imputabilidade é ainda tema questionável, poucos juízes teriam as formações necessárias para analisar o caso e chegar à conclusão se houve ou não julgamento moral feito pelo indivíduo. Assim, certamente, boa parte dos criminosos psicopatas seria condenada comumente, conforme preceitua o Código Penal, e seriam encarcerados em prisões juntamente com outros criminosos comuns.

prisioneiros juvenis homens são psicopatas; psicopatas cometes quatro vezes mais crimes violentos do que outros criminosos, além de ter maior taxa de reincidência (eles conseguem manipular os carcerários, além de interpretar o papel de prisioneiro ideal). 
Neste sentido, há dois pontos que merecem relevância. O primeiro é a questão da fixação de pena. Os juízes que acreditarem não ser possível a aplicação da semi-imputabilidade nos casos de psicopatas podem, ao contrário, entender uma maior periculosidade desses indivíduos, aumentando o mínimo legal na primeira fase de dosimetria da pena. Logo, mesmo que o crime de um psicopata tenha sido perfeitamente correspondente a um crime de um sujeito comum, a pena do primeiro seria elevada no mínimo legal, no que tange à sua personalidade, ${ }^{246}$ a título de punição - questiona-se, então, se isso seria de alguma maneira eficaz para punir o psicopata, e prevenir outros crimes.

Além disso, não há prisões "especiais" para os psicopatas, eles cumprem a pena em conjunto com outros criminosos, de todas as espécies. Como têm profunda habilidade em manipulação, irão manipular outros presidiários a fazer rebeliões, a carcerários para atingir seus objetivos, e serão rapidamente liberados da cadeia, pois que serão presos exemplares.

Utilizando-se da pesquisa jurisprudencial, nos processos de competência estadual $^{247}$, é possível concluir a inexistência ou poucos comentários acerca da psicopatia, nos mais diversos tribunais de justiça. Analisando os principais tribunais de cada região brasileira, podemos observar o quão escasso é este debate. Utilizando as palavras-chave “psicopata" e "psicopatia”, estes são os acórdãos que foram encontrados ${ }^{248}$ :

1. Tribunal de Justiça do Acre - Não há resultados.

2. Tribunal de Justiça de Alagoas - Quatro resultados. No primeiro, o termo "psicopata" é utilizado pela defesa, tentando demonstrar que o paciente é um pai de família, de bons antecedentes, e não um psicopata. Por esta razão, não deveria ficar preso após decisão de pronúncia. ${ }^{249}$ No segundo caso, a reprodução de sentença de pronúncia que se manifesta no sentido de que a ré tem personalidade psicopática, vez que é "plenamente consciente do que faz, mas

\footnotetext{
${ }^{246}$ Conforme preceitua o art. 59 do Código Penal.

247 A escolha pela competência estadual se dá por conta das maiorias de crimes cometidos pelos psicopatas estar nos tribunais de justiça (por exemplo, homicídio). Isso não afasta a possibilidade de crimes federais cometidos por estes sujeitos.

${ }^{248}$ Resultados de pesquisa realizada até $31 / 10 / 2012$.

${ }^{249}$ HABEAS CORPUS N 2008.000222-8.
} 
passa por cima de qualquer pessoa, para atingir seus objetivos escusos.". Importante destacar que tal sentença reproduzida ainda afirma que "caso se configure em uma psicopatia, não o sei, tal não torna a pessoa inimputável, mas altamente periculosa e nociva à sociedade, até porque, a psicopatia interage no campo da consciência emocional, ou seja, um psicopata não tem a capacidade de amar, de sentir compaixão pelo próximo, eles ouvem a música mas não entendem a melodia, são frios, calculistas, egocêntricos, e o próximo, é um objeto que é usado e abusado até perder a capacidade de se reerguer emocionalmente e financeiramente, quando assim é descartado pelo psicopata, que de forma rápida, procura a próxima vítima.. ${ }^{250}$ No terceiro caso, diante de sentença condenatória, afirma-se "É de bom alvitre esclarecer que temos visto na sociedade casos semelhantes, onde crimes bárbaros não geram nenhum remorso ou arrependimento em mentes com indícios de psicopatia, pelo que, em execucãa penal, é importante ressaltar a análise da psicologia do réu, posto que estarrecedoras as alusões feitas acerca de sua pessoa e personalidade, e que constam dos depoimentos dos autos para se chegar a uma conclusão acerca de sua periculosidade (comprovada nos autos) ao meio social em que vivemos." ${ }^{251}$ No quarto caso, é dito que "Aduz o eminente Procurador, que o MM. Juiz aplicou a pena-base acima da média que seria de 25 (vinte e cinco) anos, ou seja, levando-se em conta as circun4âncias do art. 59 do CP, fixou a pena-base em 27 (vinte e sete) anos e 10 (dez) meses de reclusão, desconsiderando, segundo o parquet de $2^{\mathrm{a}}$ Instância a psicopatia de que o Apelante é portador, o que diminuiria sua culpabilidade." ${ }^{25}$

3. Tribunal de Justiça do Amapá - Quatro resultados. No primeiro caso, durante a exposição dos fatos, narra o desembargador que a vítima de e ameaça depôs na delegacia e afirmou que seu companheiro era um psicopata pois "pois ora the ameaça, ora diz que a ama, que quer voltar a viver com ela". ${ }^{253} \mathrm{O}$ segundo caso é uma Apelação na qual o réu, após ser condenado pelo júri, afirma que os jurados foram influenciados uma vez que o promotor de justiça, durante todo o julgamento, estava lendo um livro denominado "Mentes Psicopatas". ${ }^{254}$ O terceiro caso é referente a criminosos que se intitulavam "Galera dos psicopatas" e cometiam diversos crimes. ${ }^{255}$ Por fim, o último caso também é Habeas Corpus em que o réu é doente mental comprovadamente (é inscrito no sistema de saúde como doente mental e tem passe livre em ônibus como doente mental), e que um dos desembargadores discute se o mesmo seria psicopata e o que deveria ser feito com o mesmo, conforme trecho do voto: "Bom, Excelência, eu acho assim: os direitos humanos estão no mundo inteiro, nos Estados Unidos da América, onde se procura protegê-los, na Noruega, na Dinamarca, na França, na Alemanha, na Inglaterra, onde estão adotando a castração química. Por que razão não se adotar a mesma medida aqui? Veja-se que já se chegou à conclusão de que psicopatia, ela não progride para a cura, e sim, para o agravamento. Isto é, pode levar para internamento, pode submeter a qualquer outro tipo de tratamento. Paciente, na hora em que tiver liberdade, vai voltar reincidir na mesma prática. .256

4. Tribunal de Justiça do Amazonas - Não há resultados.

\footnotetext{
${ }^{250}$ RECURSO EM SENTIDO ESTRITO No $3.0247 / 2010$.

${ }^{251}$ APELAÇÃO No $3.0236 / 2010$.

${ }^{252}$ APELAÇÃO No 2001.000801-2.

${ }^{253}$ APELAÇÃO n ${ }^{\circ}$ 00444434-04.2009.8.03.0001.

${ }^{254}$ APELAÇÃO n ${ }^{\circ}$ 0011435-32.2008.8.03.0001.

${ }^{255}$ APELAÇÃO n ${ }^{\circ} 2209 / 05$.

${ }^{256} \mathrm{HC} \mathrm{n}^{\circ}$ 0000812-38.2010.8.03.0000.
} 
5. Tribunal de Justiça da Bahia - Não há resultados.

6. Tribunal de Justiça do Ceará - Não há resultados.

7. Tribunal de Justiça do Distrito Federal - Quatro resultados. O primeiro é sobre inexistência de recurso do MP diante de sentença condenatória ao réu Lindomar, ao qual o desembargador afirma, sem maiores aprofundamentos, ser um "verdadeiro psicopata". ${ }^{257} \mathrm{O}$ segundo caso é um habeas corpus com denegação de ordem ao paciente que tinha bons antecedentes e era primário, pois o mesmo tinha "personalidade psicopata". ${ }^{258} \mathrm{O}$ terceiro caso é de um indivíduo condenado por roubo, no qual foi reconhecida a psicopatia e o mesmo considerado semi-imputável, conforme trecho da ementa: "3. Tratandose de réu semi-imputável, pode o juiz optar entre a redução da pena (Art. 26, parágrafo único, CP) ou aplicação de medida de segurança, na forma do art. 98, do CP. 4. Confirmado, por laudo psiquiátrico, ser o réu portador de psicopatia em grau extremo, de elevada periculosidade e que necessita de especial tratamento curativo, cabível a medida de seguranca consistente em internação, pelo prazo mínimo de 3 anos ${ }^{\text {259 }}$ Por fim, o último caso é uma apelação cível em decorrência de sentença que versou sobre anulação de casamento sem contestação do réu, o que não configuraria conluio entre as partes e não significaria que o mesmo seria psicopata, podendo ser um sociopata. ${ }^{260}$

8. Tribunal de Justiça do Espírito Santo - Não há resultados.

9. Tribunal de Justiça de Goiás - Não há resultados.

10. Tribunal de Justiça do Maranhão - Não há resultados.

11. Tribunal de Justiça do Mato Grosso - Nove resultados. O primeiro é um Habeas Corpus em que, durante a ação penal, a defensoria pública pediu a instauração de incidente de sanidade mental, pois o paciente apresentava indícios de psicopatia. ${ }^{261} \mathrm{O}$ segundo caso é referente à transcrição da inquirição de um perito psiquiátrico pelo defensor público durante a audiência de instrução e julgamento, na qual o perito é perguntado sobre um laudo que emitiu atestando ser um indivíduo (que não o apelante) psicopata. ${ }^{262} \mathrm{O}$ terceiro caso o termo "psicopata" aparece como apelido de um dos réus. ${ }^{263}$ Outro caso o réu é chamado de "psicopata" pela vítima, pois o mesmo costuma a morder sempre e deveria tomar remédios. ${ }^{264} \mathrm{O}$ quinto caso faz referência à depoimento de testemunha que afirma o réu ser uma pessoa psicopata e perigosa. ${ }^{265} \mathrm{O}$ sexto caso faz apenas referência ao apelante, afirmando que testemunhas deveriam refletir e verificar que o mesmo não poderia ter personalidade psicopata. ${ }^{266}$ Outro caso traz trecho de laudo médico afirmando que apelante não tem características de psicopatia, mas sim de neurose-obsessiva. ${ }^{267} \mathrm{O}$ penúltimo caso traz uma absolvicão imprópria de um acusado de homicídio em decorrência de sua insanidade

\footnotetext{
${ }^{257}$ APELAÇÃO nº 0010427-76.1989.807.0000.

${ }^{258} \mathrm{HC} \mathrm{n}^{\circ}$ 0005875-63.1992.807.0000.

${ }^{259}$ APELAÇÃO N ${ }^{\circ}$ 0099243-30.2009.807.0001.

${ }^{260}$ APELAÇÃO n ${ }^{\circ} 403686 / 1976$.

${ }^{261} \mathrm{HC} \mathrm{n}^{\circ} 80306 / 2010$.

262 APELAÇÃO N ${ }^{\circ}$ 85379/2010.

${ }^{263}$ APELAÇÃO no 35952/2009.

${ }^{264}$ APELAÇÃO No 91212/2008.

${ }^{265}$ RECURSO EM SENTIDO ESTRITO No 76946/2006.

${ }^{266}$ APELAÇÃO No $31587 / 2006$.

${ }^{267}$ APELAÇÃO No 56649/2006.
} 
mental, pois que pois que se tratava de réu de personalidade psicopata ${ }^{268}$ Por sua vez, o último caso, em sentido contrário, afirma que o réu, de acordo com o desembargador, "tem duas anomalias, alternativamente: ou ele é um psicopata e, nesse caso, deve sofrer de algum distúrbio psicológico, o que entretanto não lhe dá o caráter de inimputabilidade de seus atos, porque o psicopata conhece o que está fazendo, apenas sofre de distúrbio momentâneo, mas não é permanente; ou ele deve sofrer de distúrbio de caráter moral."

12. Tribunal de Justiça do Mato Grosso do Sul - Treze resultados. Dentre estes resultados, destacam-se julgamentos negando concessão de benefícios durante execução penal, como exemplo: "o magistrado não cerceou a defesa do ora agravante, pois oportunizou-lhe a apresentação dos quesitos que entendia pertinentes, os quais foram respondidos pelo perito em laudo complementar de exame criminológico, e somente depois é que proferiu a decisão indeferindo os pedidos de saída temporária e trabalho externo, por não preenchimento do requisito subjetivo, já que foi considerado psicopata pelo perito, que inclusive, recomendou seu afastamento do convívio social." ${ }^{270}$ e "O paciente cumpre pena total de 13 (treze) anos e 09 (nove) meses de reclusão, pela prática dos crimes de atentado violento ao pudor e sequestro. Ao atingir o lapso previsto para a progressão de regime prisional foi realizado exame criminológico, que concluiu ser "JOSÉ ROBERTO é um psicopata, a conclusão da perícia é desfavorável à concessão do benefício, deve ser mantido afastado da sociedade" (f. $\underline{11 / 12) .9271}$

13. Tribunal de Justiça de Minas Gerais - Cento e trinta e cinco resultados. Pela leitura de alguns dos acórdãos, foi possível verificar que a maioria dos resultados, novamente, só são referentes a apelidos de criminosos, descrição de indivíduos (sem a tecnicidade que procuramos) e enfermos mentais efetivos. Não houve, nos acórdãos selecionados, nenhum que demonstrasse conteúdo condizente com a presente pesquisa.

14. Tribunal de Justiça do Paraná - Trinta e três resultados. Todos os resultados trazem os termos "psicopata" e "psicopatia" apenas como denominações pejorativas, ou, ainda, como sinônimo de enfermo mental completo, não no sentido técnico da palavra que buscamos nessa pesquisa.

15. Tribunal de Justiça da Paraíba - Não há resultados.

16. Tribunal de Justiça do Pará - Não há resultados.

17. Tribunal de Justiça de Pernambuco - Não há resultados.

18. Tribunal de Justiça do Piauí - Não há resultados.

19. Tribunal de Justiça do Rio de Janeiro - Três resultados. O primeiro caso apenas diz que o apelante, menor de idade, não teria sintomas indicativos de um transtorno psiquiátrico grave com características psicóticas ou psicopatas. ${ }^{272}$ Já o segundo caso é referente a um Habeas Corpus com a ordem denegada, uma vez que a prisão do acusado foi considerada legítima, por "tratar-se o paciente de um psicopata e que 'não segregar o indiciado é expor as testemunhas à

${ }^{268}$ RECURSO EX OFFICIO - CLASSE I - 22 - No 305/00.

${ }^{269}$ APELAÇÃO No 3.816/01.

${ }^{270}$ AGRAVO EM EXECUÇÃO 2011.021621-2/0000-00.

${ }^{271}$ HABEAS CORPUS n. 2011.008470-1/0000-00.

${ }^{272}$ APELAÇÃO n. 0002451-42.2011.8.19.0055. 
risco desnecessário e real, maculando a futura producão desta prova em juizo",273 Por fim, o último caso é de um indivíduo que, na direção de veículo automotivo, ocasionando a morte de uma jovem e lesão corporal com deformidade permanente em outra, além de lesões em terceiro. Sua pena foi detenção de 04 anos substituída por duas restritivas de direitos, a saber, entrega de donativo a uma instituição, no valor equivalente a 10 salários mínimos, e prestação de serviços à comunidade. A apelação quis, simploriamente, pretender sua total exoneração, afirmando-se portador de psicopatia, e hipossuficiência. ${ }^{274}$

20. Tribunal de Justiça do Rio Grande do Norte - Um resultado. Agravo em execução, em decorrência da não concessão de progressão de regime, uma vez que o teste psicológico do agravante traz fortes indícios de que o mesmo ou é esquizofrênico ou é psicopata (podendo ser ambos). ${ }^{275}$

21. Tribunal de Justiça do Rio Grande do Sul - Vinte e dois resultados. Dos julgados, destacam-se os seguintes: "2.2. Comprovado pelo laudo psiquiátrico que o réu ao tempo do crime padecia de transtorno anti-social de personalidade, a redução de pena é obrigatória, o que é facultativo é o quantum maior ou menor (1/3 a $2 / 3)$ dessa diminuição de pena. 2.3. A consequência legal da capacidade relativa de culpabilidade por perturbação da saúde mental ou por outros estados patológicos, é a redução obrigatória da pena, pois se a pena não pode ultrapassar a medida da culpabilidade, então a redução da capacidade de culpabilidade determina, necessariamente, a redução da pena. Argumentos contrários à reducão da pena no sentido do cumprimento integral da pena são circulares, inconvincentes e desumanos porque 0 mesmo fator determinaria, simultaneamente, a reducão da culpabilidade (psicopatias ou debilidades mentais explicariam a culpabilidade) e a agravação da culpabilidade (a crueldade do psicopata ou débil mental como fator de agravação da pena)." 276 , "AGRAVO EM EXECUÇÃO. PROGRESSÃO DE REGIME. CONDIÇÕES SUBJETIVAS. A progressão de regime assenta-se na conjugação favorável dos requisitos objetivos e subjetivos a informarem modificação de comportamento e condições que permitam ao apenado ser transferido de regime mais rigoroso a outro menos rigoroso, em gradual reinserção no meio social. Hipótese na qual o preso ostenta atestados carcerários de conduta plenamente satisfatória, consignando, a psicóloga, que a boa conduta deriva apenas da contenção, constatando quadro clínico de psicopatia. Apenado que narra com extrema frieza o latrocínio cometido, sem traços de arrependimento" 277 e "Continuidade delitiva afastada. Psicopatia moderada, apontada por laudo de avaliação psicológica, que caracteriza perturbacão com óbvia repercussão sobre a faculdade psíquica da volicão, ensejando o enquadramento do acusado na situação do art. 26, parágrafo único, do CP. Semi-imputabilidade reconhecida." ${ }^{278}$

22. Tribunal de Justiça de Roraima - Não há resultados.

\footnotetext{
${ }^{273}$ HABEAS CORPUS N. 2001.059.00776.

${ }^{274}$ APELAÇÃO N. 2006.050.04678.

${ }^{275}$ AGRAVO EM EXECUÇÃO n 2007.007733-2.

${ }^{276}$ APELAÇÃO N. 70037449089.

${ }^{277}$ APELAÇÃO N. 70037159431.

${ }^{278}$ APELAÇÃO N. 70016542557.
} 
23. Tribunal de Justiça de Santa Catarina - Todos os resultados encontrados utilizaram o termo "psicopatia" para denominar doença mental grave, e não no mesmo sentido desta pesquisa. ${ }^{279}$

24. Tribunal de Justiça de Sergipe - Não há resultados.

25. Tribunal de Justiça de São Paulo - Não há resultados.

26. Tribunal de Justiça de Tocantins - Um resultado. Trata-se de um Habeas Corpus no qual o paciente foi acusado de sua própria filha. Foi considerado inimputável, sendo aplicada medida de segurança de internação. Inexistindo Hospital de Tratamento e Custódia adequados, foi impetrado o HC para que o mesmo aguardasse em liberdade. A decisão dos magistrados foi no sentido de negar a ordem, uma vez que "se posto em liberdade, os filhos e a própria companheira do réu correriam risco de morte ademais, submetido, no corrente ano, a exame de cessação de periculosidade foi constatado que o reeducando é portador de transtorno de personalidade, psicopata, sendo considerado perigoso ao convívio social mesmo após o tratamento psiquiátrico disponível e, mesmo após o ano de internacão sem ingestão de bebida alcoólica, não conserva qualquer julgamento de valor ético-moral."280

27. Superior Tribunal de Justiça - Não há resultados.

28. Supremo Tribunal Federal - Seis resultados. A maioria dos acórdãos menciona o termo "psicopatia" e "psicopata", alguns imputando tal característica a criminosos (de forma atécnica), outros citando apenas como referência de exames criminológicos para concessão de benefícios. Nenhum acórdão, porém, tem decisão específica estudada e baseada na psicopatia do sujeito que mereça destaque.

Assim, como é possível verificar, a atuação do Judiciário perante os psicopatas não é, de nenhum forma, unânime. Alguns juízes entendem que o individuo psicopata é semi-imputável, devendo ser aplicada alguma medida de segurança. Por sua vez, há que entenda, também, serem os psicopatas completamente imputáveis, merecendo rigorismo na pena por conta de sua personalidade.

A legislação penal brasileira também não é muito diferente do judiciário. Se por um lado não há, no sistema legal, nenhuma proposição efetiva em verificar a psicopatia no criminoso, não há, também, nenhuma previsão normativa que implique nessa verificação.

\footnotetext{
279 Exemplos: AGRAVO DE INSTRUMENTO n. 2009.005252-5, APELAÇÃO CÍVEL n 2008.041425-8, APELAÇÃO CÍVEL 2006.009090-4.

${ }^{280}$ HABEAS CORPUS n. 4246/2006.
} 
Não há nenhuma lei, decreto, portaria, regulamento ou congênere que mencione, mesmo que indiretamente, a psicopatia. Isso apenas reforça e demonstra a incipiência do tema no Brasil, que aparece aos poucos e em casos isolados. A Lei de Execução Penal (Lei 7210/1984) menciona, em alguns pontos, a realização de exames criminológicos, por exemplo, a fim de individualização da execução (artigo $8^{\circ}$ ) e com vista a analisar o internado (artigos 100 e 175).

Entretanto, há, atualmente, um projeto de $1 \mathrm{i}^{281}$ proposto pelo deputado federal Marcelo Itagiba, prevendo a alteração na Lei de Execução Penal para criar uma comissão técnica independente da administração prisional e prevendo a execução da pena do condenado psicopata, estabelecendo a realização de exame criminológico do condenado a pena privativa de liberdade.

Em sua justificação, o deputado afirma a importância dos psicopatas cumprirem a pena imposta separadamente dos presos comuns, além de obrigar o exame criminológico minucioso por profissional qualificado como requisito obrigatório para conceder benefícios tais como livramento condicional e progressão de regime. Este projeto, no momento, aguarda apreciação em plenário desde março de 2010.

Outro projeto de $1 \mathrm{ei}^{282}$, instituído pelo deputado federal Carlos Lapa, prevê a criação de uma "medida de segurança social perpétua para psicopatas considerados incorrigíveis, que cometem assassinato em série". Em suas razões do projeto, afirma que tais sujeitos são de uma espécie híbrida, já que são acometidos de um mal incurável, incorrigível e que seriam altamente perversos em suas ações criminosas, possuindo uma inteligência acima do normal, não podendo ser considerados normais, mas

\footnotetext{
${ }^{281}$ PL 6858/2010. Para maiores informações, verificar a justificação do deputado, disponível em: 〈http://www.camara.gov.br/sileg/integras/737111.pdf>.

${ }^{282}$ PL 3/2007. Para maiores informações, verificar a justificação do deputado, disponível em: $<$ http://www.camara.gov.br/proposicoesWeb/prop mostrarintegra;jsessionid=6292523A741CB5F E8CBEB4B467AC2F4A.node2?codteor=433883\&filename $=\mathrm{PL}+3 / 2007>$.
} 
também não são tecnicamente loucos. Assim, propõe a criação de tal medida para que os afastem da sociedade permanentemente, evitando os crimes bárbaros na sociedade (conforme explica o deputado).

Cumpre ressaltar, por consequência de tal ausência legislativa, que a questão do psicopata é claramente um caso difícil do direito. Não há nenhuma lei penal brasileira que amolde a hipótese de crime cometido por psicopata, evidenciando uma lacuna normativa que influencia nos julgamentos feitos pelos juízes.

Em outras palavras, por não existir nenhuma regra que preveja a obrigação de exames em criminosos, a fim de constatar a psicopatia, ou então alguma norma que obrigue a conduta judicial nos casos de psicopatia (implicando a semi-imputabilidade, ou então a previsão de uma prisão própria), os juízes passam a decidir conforme a legislação comum, eis que tais criminosos passam a ser considerados comuns. Isso acaba não sendo efetivo, exatamente porque os psicopatas não são criminosos comuns. Desta maneira, ensina o professor Noel Struchiner:

Quando as regras, tomadas abstratamente ou no momento de aplicação, não são capazes de resolver satisfatoriamente um caso concreto, então surge um caso difícil ou insólito. ${ }^{283}$

Uma breve comparação com os Estados Unidos e se pode ver que diversos estados americanos previram leis que mencionam psicopatas. Em sua maioria, são leis relacionadas aos predadores sexuais, que preveem um confinamento para tratamento destes posteriormente ao cumprimento da pena. $^{284}$

\footnotetext{
${ }^{283}$ STRUCHINER, Noel. Para falar de regras: o positivismo conceitual como cenário para uma investigação filosófica acerca dos casos difíceis do direito. Orientador: Danilo Marcondes de Souza Filho. Rio de Janeiro: PUC-Rio. Departamento de Filosofia. 2005. p. 15.

${ }^{284}$ EDENS, Johns.; PETRILA, John. Legal and Ethical Issues in the Assessmentand Treatment of Psychopathy - Handbook of Psychopathy. Nova York: The Guilford Press, 2006. p. 574.
} 
Em Washington, há uma lei de 1990 que define os psicopatas sexuais como aqueles que já foram condenados em algum crime sexual previamente, e provavelmente vai cometer outro se estiver livre. Em Minnessota, por sua vez, há uma lei de 1939 que define o que seria uma personalidade psicopata ("instabilidade emocional, comportamento impulsivo, etc."). ${ }^{285}$

Além de a legislação norte-americana especificar a psicopatia em certas leis, não é difícil encontrar casos de psicopatas. É possível citar casos famosos, como Ted Bundy, Bernie Madoff e Tom Parker. A jurisprudência norte-americana também é farta quando trata, por exemplo, dos casos de psicopatas sexuais, como o caso People vs Levy ${ }^{286}$ e o People vs Good. ${ }^{287}$ Assim, resta evidente que as cortes norte-americanas estão muito mais preparadas que as brasileiras para atuar nos casos específicos dos psicopatas.

A importância de legislação e punição específica para os psicopatas é também em decorrência do fato de que a cura deles é praticamente impossível. Cleckely afirmava que os psicopatas não tinham a capacidade de formar vínculos emocionais para uma terapia efetiva, e, portanto, não se beneficiaria dela. $^{288}$ Por sua vez, Edens e colegas verificaram que, na verdade, não há base de informações acerca dos tratamentos psicológicos suficiente para afirmar se os psicopatas são ou não tratáveis. ${ }^{289}$

Desta maneira, a atenção que deve ser dada aos psicopatas torna-se maior, uma vez que é questionável a eficácia dos tratamentos nestes indivíduos, não os impedindo de continuar a cometer crimes.

\footnotetext{
285 LIEB, Roxanne. Washington's Sexually Violent Predator Law: Legislative History and Comparisons With Other States. Washington: Washington State Institute for Public Policy, dez. 2006.

${ }^{286}$ Disponível em: 〈http://law.justia.com/cases/california/calapp2d/151/460.html〉. Acesso em: 23 jul. 2011.

${ }^{287}$ Disponível em: 〈http://law.justia.com/cases/california/calapp2d/223/298.html〉. Acesso em: 23 jul. 2011.

${ }_{288}$ HUSS, MATTHEW T. Op. cit., p. 107.

${ }^{289}$ EDENS, Johns. et al., Op. cit., p. 584.
} 
Portanto, conforme pudemos ver, o Direito Penal Brasileiro é, ainda, muito incipiente no que tange ao tratamento dos psicopatas. Em primeiro lugar, não se observam estudos e pesquisas sérias sobre o tema (sem intuito de aterrorizar a população de forma midiática e apelativa). As universidades e faculdades de Direito se abstém de investigar tais indivíduos, em um reflexo direto da sociedade que sabe da existência de tais sujeitos, mas preferem ignorar qualquer diferenciação de tratamento.

Em segundo lugar, uma dificuldade latente que se encontra é da falta de capacitação profissional de peritos psiquiatras capazes de qualificar um indivíduo como psicopata. Estudamos no capítulo passado o quão precisa é a medida PCL-R de Hare, devendo alguém com conhecimentos manuseá-la para ter um resultado correto se um indivíduo é ou não psicopata.

Ainda que houvesse tal capacitação, em pouco iria influenciar nos julgamentos dos juízes e, havendo condenação, nas consequências destas. Diagnosticado como psicopata, pudemos ver, na pesquisa jurisprudencial, que há juízes que entendem a capacidade reduzida de conhecimento da antijuridicidade da ação e aplicam o art. 26, caput ou parágrafo $1^{\circ}$ do Código Penal. Por sua vez, há quem entenda que o fato de ser psicopata é uma agravante, devendo ter penas mais severas que o criminoso "comum".

Tal inconstância do Judiciário remete, ainda, a um problema da execução da pena ou medida de segurança. Colocar um psicopata junto com outros condenados em uma prisão comum não seria o mais correto. Sua habilidade de persuadir os carcereiros e de liderar rebeliões e fugas é consequência das características inerentes à psicopatia. Ademais, seu comportamento exemplar e fingimento de arrependimento levariam aos psicólogos e psiquiatras responsáveis em realizar exames importantes, por exemplo, para progressão de regime e livramento condicional, a darem resultados positivos e permissivos à concessão de tais benefícios, reinserindo tais indivíduos na sociedade. 
Aplicar uma medida de segurança em Hospitais de Tratamento e Custódia ou tratamento ambulatorial comum também não parece ser a medida mais efetiva. Conforme já pudemos perceber, os psicopatas não são doentes mentais e não padecem de sintomas similares àqueles esquizofrênicos ou dementes. Interná-los nestes hospitais juntos com outros indivíduos que realmente têm enfermidade mental não parece, de forma alguma, ser um tratamento efetivo. Além disso, o simples tratamento ambulatorial também não indica ser o melhor caminho para reabilitar tais indivíduos na sociedade.

Portanto, observando todo o exposto neste capítulo, é de facilidade extrema perceber que os psicopatas não recebem nenhuma atenção específica da doutrina, Judiciário e Legislativo brasileiros, impedindo que tais indivíduos tenham uma penalização adequada e tratamento devido. 


\section{CONCLUSÃO}

Pelo que pudemos apreender, a Teoria do Crime nos trouxe conceitos muito importantes para compreender o Direito Penal. Estudar as diversas correntes acerca do conceito de "crime" é importante para que se possa fazer uma pesquisa acurada de seus principais elementos: tipicidade, antijuridicidade e culpabilidade.

Neste sentido, destaca-se a importância do elemento culpabilidade. A evolução histórica demonstrou que, ao longo dos séculos, o distanciamento da responsabilidade penal objetiva tornou o Direito Penal mais hígido e justo. Chegar aos dias de hoje entendendo como culpável aquele indivíduo que, sabendo da antijuridicidade da conduta e mesmo assim a comete, havendo possibilidade de não cometer, é um grande avanço histórico.

A imputabilidade, então, tratou de focar no estudo de certos indivíduos criminosos, para verificar se todos os elementos que os considerem imputáveis estarão presentes. Conforme vimos, a imputabilidade é a regra, enquanto a inimputabilidade é a exceção.

O Direito Penal, em sua função mais salutar, viu por bem elencar, em seu art. 26 do Código Penal, a inimputabilidade. Destacar do tratamento comum a que se dá aos inimputáveis é de extrema importância, já que tais indivíduos, acometidos de doença mental, são incapazes de, ao tempo da ação, ter plena consciência que a mesma é antijurídica e se conduzir com tal entendimento.

Da mesma forma determinou, em seu parágrafo único, a existência dos semi-imputáveis - aqueles que não são completamente insanos, mas que, ao tempo da ação, em decorrência de perturbação mental, acaba não conseguindo verificar a ilicitude do seu agir e, por tal entendimento, comete 
algum crime. Nestes casos, o legislador deu ao juiz a possibilidade de aplicar uma medida de segurança ou condenar em uma pena reduzida.

Para que se verifique a imputabilidade ou não de certo indivíduo (exceto nos casos biológicos, em que a maioridade é o único marco que distingue), é necessária a interdisciplinaridade entre o Direito e a Psicologia Forense.

O cotejo entre o Direito e a Psiquiatria/Psicologia forense tem sido cada vez mais necessário. Estudar o criminoso em sua personalidade, além dos elementos sociais e antropológicos que normalmente os doutrinadores focam, se torna importante, diante de uma sociedade que desconhece seus criminosos.

Quanto a este desconhecimento, não se faz referência a saber quem é o chamado "condenado clássico" do Direito Penal (negros de baixa renda). Importa ter consciência de que cada indivíduo que comete crime pode ser, ou não, um psicopata. E tal fato é completamente ignorado pelo Direito Penal Brasileiro.

A lacuna em relação à psicopatia é enorme. Conforme pudemos aprender, não há nenhuma lei que cuide de tais indivíduos, seja para determinar a realização de exame médico específico (PCL-R de Hare, ou então uma ressonância magnética, ou qualquer congênere), seja para aplicar a sanção mais adequada (pena privativa de liberdade, medida de segurança ou outro tratamento a ser criado). Eles simplesmente são ignorados e se tornam mais um na sociedade encarcerada.

Ademais, a pouca produção doutrinária acerca do tema deixa os juízes sem embasamento algum para decidir diante de um tema tão complicado quanto este. Supondo o diagnóstico de psicopatia, o que fazer? Aplicar o art. 26, parágrafo único do Código Penal? Aumentar sua pena- 
base na $1^{\mathrm{a}}$ fase de dosimetria da pena, com base em sua personalidade, nos termos do art. 59 do Código Penal?

Muitas destas perguntas não são resolvidas, na prática. A pesquisa jurisprudencial realizada demonstrou que, excetuando aqueles milhares de casos em que os termos "psicopatia" e "psicopata" vieram vazios, sem o seu real significando, com único intuito de desprezar o réu, os juízes decidiram das duas maneiras. Enquanto alguns consideravam a semi-imputabilidade destes sujeitos, aplicando uma medida de segurança, outros consideravam tais pessoas de extrema periculosidade, necessitando cumprir uma pena proporcional à sua periculosidade social.

Assim, como vemos, as manifestações dos magistrados são radicalmente opostas, o que merece destaque. Alguns consideram semiinimputáveis ou inimputáveis. Outros acreditam que aumentar a pena seria a maneira mais adequada de lidar com estes indivíduos.

Tampouco os legisladores se atentaram a qualquer previsão quanto a tais sujeitos. A inexistência de leis capazes de balizar o tratamento dos psicopatas, seja durante o processo criminal, seja na execução da pena, destaca o descaso quanto a este assunto. Apesar de já ter sido demonstrado que o índice de reincidência dos psicopatas é enorme, a política criminal do país prefere ignorar estes fatos ao aplicar as mesmas leis e mesmo tratamento dos criminosos comuns aos psicopatas, sem sequer questionar a efetividade de tal aplicação.

Desta forma, a presente pesquisa, que em nenhum momento pretendeu esgotar todo o tema, sendo certo que há muito a ser lido e pesquisado, concluiu que a figura do psicopata no ordenamento brasileiro é quase nula. Poucos artigos estão sendo publicados, alguns doutrinadores arriscam falar do tema. Os juízes não são unânimes da responsabilidade penal dos psicopatas, resolvendo cada caso concreto de forma diferenciada. A lei é omissa. 
Pretendemos, então, atiçar a fagulha de cada penalista brasileiro, para que se inicie uma pesquisa séria e focada, a fim de tentarmos dar uma melhor resposta a estes indivíduos, acometidos de uma doença mental hipotética, de etiologia desconhecida, patologia ignorada, tratamento incógnito e cura impossível ${ }^{290}$ - e que certamente estão ao nosso redor.

${ }^{290}$ THOMPSON, Augusto. Quem são os criminosos? O crime e o criminoso, entes políticos. Rio de Janeiro: Editora Lumen Juris, 1998. p. 110. 


\section{REFERÊNCIAS BIBLIOGRÁFICAS}

ALEXANDER, Larry.; MOORE, Michael. Deontological ethics. nov. 2007. Disponível em: <http://plato.stanford.edu/entries/ethicsdeontological/>. Acesso em: 19 jul. 2011.

BIERRENBACH, Sheila. Teoria do Crime. Rio de Janeiro: Editora Lumen Juris, 2009.

BITENCOURT, Cezar Roberto. Tratado de Direito Penal Parte Geral. $10^{\mathrm{a}}$ ed. São Paulo: Editora Saraiva, 2006.

CAMARA, Alexandre. Lições de direito processual civil. v. III. $16^{\mathrm{a}}$ ed. Rio de Janeiro: Lumen Juris, 2010.

CIMA, Maaike.; TONNAER, Franca.; HAUSER, Marc D. Psychopaths know right from wrong but don't care - Social Cognitive \& Affective Neuroscience, v. 5, Issue 1.

CLECKLEY, Hervey. The mask of sanity. $5^{\text {a }}$ ed. "scanned facsimile produced for non-profit educational use". Disponível em: $<$ http://cassiopaea.org/cass/sanity 1.PdF>. Acesso em: 9 de jul. 2011.

COVELLI, Luciano A. La Psicopatia en la condena y en la ejecución de la pena privativa de libertad. Buenos Aires: Revista de Derecho Penal. n. 1, 2009.

CUSHMAN, F.; GREENE, J.; YOUNG, L. The Multi-system PsychologyThe Moral Psychology Handbook. Oxford University Press, USA. July 6, 2010.

DELMANTO, Celso et al., Código penal comentado. $8^{\mathrm{a}}$ ed. São Paulo: Saraiva, 2010.

EDENS, John.; LILIENFELD, Scott O.; MARCUS, David K.; POYTHRESS JR, Norman G. Psychopathic, Not Psychopath: Taxometric 
Evidence for the Dimensional Structure of Psychopathy. v. 115, no. 1. Journal of Abnormal Psychology, 2006. p. 131-144.

EDENS, John.; PETRILA, John. Legal and Ethical Issues in the Assessment and Treatment of Psychopathy. Handbook of Psychopathy. Nova York: The Guilford Press, 2006.

FRAGOSO, Heleno Cláudio. Lições de Direito Penal (parte geral). $16^{\mathrm{a}}$ ed. Rio de Janeiro: Editora Forense, 2004.

FUHRER, Maximiliano. Tratado da inimputabilidade no Direito Penal. São Paulo: Editora Malheiros, 2000.

GLENN, Andrea.; KURZBAN, R.; \& RAINE, A. (in press). Evolutionary Theory and Psychopathy. Aggression and Violent Behavior.

GLENN, Andrea.; RAINE, A.; LAUFER, W.S. Is it wrong to criminalize and punish psychopaths? no. 3. Emotion Review, 2011. p. 302-304.

GLENN, Andrea.; RAINE, A.; SCHUG, R.A. The neural correlates of moral decision-making in psychopathy. no. 14. Molecular Psychiatry, 2009. p. 5-6.

GRECO, Rogério. Curso de Direito Penal - Parte Geral. v. I. $11^{\mathrm{a}}$ ed. Niterói: Ímpetus, 2009.

GREENE, Joshua. Moral Dilemmas and the "Trolley Problem". Disponível em: <http://www.wjh.harvard.edu/ jgreene/>. Acesso em 13 jul. 2011.

GREENE, Joshua.; SOMMERVILLE, Brian.; NYSTROM, Leigh.; DARLEY, John.; COHEN, Jonathan. An fMRI Investigation of Emotional Engagement in Moral Judgment - SCIENCE. v. 293. 2001.

HASSEMER, Winfried;. CONDE, Francisco M. Introduccion a la criminologia y al derecho penal. Valencia: Tirant Lo Blanch, 1989.

HUEBNER, Bryce.; DWYER, Susan.; HAUSER, Marc. The role of emotion in moral psychology - Trends in Cognitive Sciences. v. Xxx. no. (in press) 
HUSS, MATTHEW T. Psicologia Forense. $1^{\mathrm{a}}$ ed. Porto Alegre: Editora Artmed, 2011.

JESUS, Damásio de. Direito Penal - Parte Geral. $31^{\mathrm{a}}$ ed. São Paulo: Editora Saraiva, 2010.

KENNETT, Jeanette.; FINE, Cordelia. In: Internalism and the Evidence from Psychopaths and"Acquired Sociopaths" - SINNOTT-ARMSTRONG, Walter - Moral Psychology - The Neuroscience of Morality: Emotion, Brain Disorders, and Development. v. 3. MIT PRESS: Cloth / January 2008 p. 173.

KIEHL, Kent A. In: Without Morals: The Cognitive Neuroscience of Criminal Psychopaths. SINNOTT-ARMSTRONG, Walter. Moral Psychology - The Neuroscience of Morality: Emotion, Brain Disorders, and Development. v. 3. MIT PRESS: Cloth / January 2008.

LIEB, Roxanne. Washington's Sexually Violent Predator Law: Legislative History and Comparisons With Other States. Washington: Washington State Institute for Public Policy, 2006.

LÓPEZ BOLADO, Jorge Daniel. La inimputabilidad del psicopata Doctrina Penal: Teoria y pratica em las ciências penales. v. 9. Buenos Aires. p. 33-36.

LYKKEN, David T. In: Psychopathic personality: the scope of the problem - Handbook of Psychopathy. Nova York: The Guilford Press, 2006.

MILLON, Theodore.; SIMONSEN, Erik.; BIRKET-SMITH, Morten In: Historical conceptions of psychopathy in the United States and Europe Psychopathy: antisocial, criminal and violent behavior. Nova York: The Guilford Press, 1998.

MOLL, Jorge.; OLIVEIRA-SOUZA, Ricardo.; MARROCOS, Rogerio P. In: Predadores de Corpos, predadores de almas. ed. de jan/fev/mar. Revista Insight - Inteligência, 2002. p.116-122.

MONTELLO, Maria. Rational Requirements for Moral Motivation: The Psychopath's Open Question. Philosophy Theses. Paper 93. 2011. p. 14. Disponível em: 
$<$ http://digitalarchive.gsu.edu/cgi/viewcontent.cgi?article $=1094 \&$ context $=\mathrm{p}$ hilosophy_theses> Acesso em: 20 jul. 2011.

NICHOLS, Shaun. How Psychopaths Threaten Moral Rationalism, or Is it Irrational to Be Amoral?. The Monist, 85. 2002. p. 285-304.

PIZARRO, David.; MONIN, Benoit.; BEER, Jennifer. Deciding Versus Reacting: Conceptions of Moral Judgment and the Reason. Affect Debate Review of general psychology. v. 11. no. 2. 2007. p. 99-111.

PRADO, Luiz Régis. Curso de Direito Penal Brasileiro. $9^{a}$ ed. São Paulo: Editoria Revista dos Tribunais. 2010.

PRINZ, Jesse.; NICHOLS, Shaun. Moral emotions - The Moral Psychology Handbook. Oxford University Press, USA: jul. 2010.

PUIG, Santiago Mir. Direito Penal - Fundamentos e Teoria do Direito. São Paulo: Editoria Revista do Tribunal, 2007.

RULE, Ann. The stranger beside me. Nova York: W. W. Norton and Company, 1981.

SÁNCHEZ CORRAL, José Manuel. La teoria del bem jurídico em el derecho penal liberal: contornos y protecciones a partir de uma concepcion personalista. Psicopatas e delincuentes. Estudio Psiquiatrico. Diagnostico diferencial. Buenos Aires: Revista de Derecho Penal. no.1.

SÁNCHEZ GARRIDO, Francisco José. Fisonomia de la psicopatia. Concepto, origem, causas y tratamiento legal. $3^{\mathrm{a}}$. época, no. 2. Madrid: Revista de Derecho Penal y Criminologia.

SANTOS, Juarez Cirino dos. Direito Penal. Parte Geral. $3^{\text {a }}$ ed. Curitiba: Lumen Juris, 2008.

SANTOS, Juarez Cirino. Teoria do crime. São Paulo: Editora Acadêmica, 1993.

SINNOT-ARMSTRONG, Walter. Consequentialism. mai. 2003. Disponível em: 〈http://plato.stanford.edu/entries/consequentialism/>. Acesso em: 19 jul. 2011. 
SINNOTT-ARMSTRONG, Walter. Moral Psychology - The Neuroscience of Morality: Emotion, Brain Disorders, and Development. v. 3. MIT PRESS: Cloth / January 2008.

SINNOT-ARMSTRONG, Walter.; BORG, Jana Schaich. Psychopaths and Moral Judgments - trabalho acadêmico ainda em andamento, sem referências.

STRUCHINER, Noel. Para falar de regras: o positivismo conceitual como cenário para uma investigação filosófica acerca dos casos difíceis do direito. Orientador: Danilo Marcondes de Souza Filho. Rio de Janeiro: PUC-Rio, Departamento de Filosofia, 2005.

TANGERINO, Davi. Culpabilidade. Rio de Janeiro: Elsevier, 2011.

THOMPSON, Augusto. Quem são os criminosos? O crime e o criminoso, entes políticos. Rio de Janeiro: Editora Lumen Juris, 1998. p. 110.

TUBENCHLAK, James. Teoria do Crime: O estudo do crime através de suas divisões. Rio de Janeiro: Editora Forense, 1978.

VIDING, Essi. Journal of Child Psychology and Psychiatry 45. ago. 2004. p. 1329-1337.

ZAFFARONI, Eugenio Raúl.; PIERANGELI, José Henrique. Manual de Direito Penal Brasileiro. Parte Geral. $5^{\mathrm{a}}$ ed. São Paulo: Editora Revista dos Tribunais, 2004.

ZARLENGA, Marcelo E. El psicópata perverso en la jurisprudencia argentina: una primeira aproximación. v. 6. $10^{\mathrm{a}}$ ed. Buenos Aires: Cuadernos de Doctrina y Jurisprudencia Penal, mai. 2000. 